\title{
Brookian
}

\section{Core Workshop:}

October 18-19, 2018

Depositional Setting

Potential Reservoir Facies, and Reservoir Quality in the Nanushuk Formation (Albian-Cenomanian), North Slope, Alaska

Workshop Leaders:

David L. LePain, Paul L. Decker, and Kenneth P. Helmold 


\title{
STATE OF ALASKA
}

Michael J. Dunleavy, Governor

\section{DEPARTMENT OF NATURAL RESOURCES}

\author{
Corri A. Feige, Commissioner
}

\section{DIVISION OF GEOLOGICAL \& GEOPHYSICAL SURVEYS}

Steve Masterman, State Geologist and Director

Publications produced by the Division of Geological \& Geophysical Surveys (DGGS) are available for free download from the DGGS website (dggs.alaska.gov). Publications on hard-copy or digital media can be examined or purchased in the Fairbanks office:

Alaska Division of Geological \& Geophysical Surveys 3354 College Rd., Fairbanks, Alaska 99709-3707

Phone: (907) 451-5010 Fax (907) 451-5050

dggspubs@alaska.gov | dggs.alaska.gov

DGGS publications are also available at:

Alaska State Library,

Historical Collections \& Talking Book Center 395 Whittier Street Juneau, Alaska 99811

Alaska Resource Library and Information Services (ARLIS) 3150 C Street, Suite 100

Anchorage, Alaska 99503

Suggested citation:

LePain, D.L., Decker, P.L., and Helmold, K.P., 2018, Brookian Core Workshop: Depositional setting potential reservoir facies, and reservoir quality in the Nanushuk Formation (Albian-Cenomanian), North Slope, Alaska: Alaska Division of Geological \& Geophysical Surveys Miscellaneous Publication 166, 58 p. http://doi.org/10.14509/30137
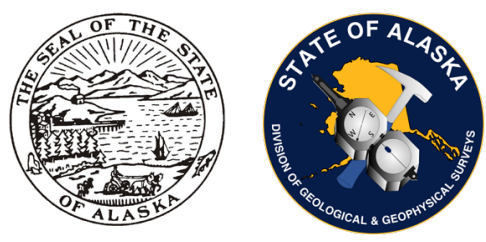


\section{BROOKIAN CORE WORKSHOP: DEPOSITIONAL SETTING, POTENTIAL RESERVOIR FACIES, AND RESERVOIR QUALITY IN THE NANUSHUK FORMATION (ALBIAN-CENOMANIAN), NORTH SLOPE, ALASKA}

David L. LePain, ${ }^{1}$ Paul L. Decker, ${ }^{2}$ and Kenneth P. Helmold ${ }^{2}$

\section{ABSTRACT}

This workshop will examine cores from five wells (Wainwright 1, Square Lake Test Well 1, Wolf Creek Test Well 3, Umiat 18, and Fish Creek Test Well 1) representing a range of depositional settings in the Nanushuk Formation, from marine-influenced lower delta plain to outer shelf. A range of lower delta plain facies associations, including bayfill, distributary channel-fills, and crevasse deltas are featured in cores from Wainwright 1, Square Lake Test Well 1, and Wolf Creek Test Well 3. Storm wave-modified shoreface and delta-front facies associations comprise significant parts of the successions cored in the Square Lake and Wolf Creek wells and demonstrate that significant stretches of the Nanushuk coastline were subjected to powerful storm waves. The cored succession in Umiat 18 is comprised of prodelta and river-dominated delta-front facies associations. Heavily oil-stained outer shelf facies associations comprise the cored interval in Fish Creek Test Well 1. This workshop highlights facies associations likely to have the best reservoir potential and examines the relative importance of depositional setting, sandstone composition, grain size, and mechanical compaction on reservoir quality (porosity and permeability).

\section{ACKNOWLEDGEMENTS}

We thank Kurt Johnson, Jean Riordan, Alexandra Busk, and Walter Zimmerman of the Alaska Division of Geological \& Geophysical Surveys Geologic Materials Center (DGGS GMC) for hosting this workshop and laying out several hundred boxes of core. Thanks to Holly Fair with the Alaska Division of Oil and Gas for preparing the page-sized seismic sections for Wolf Creek Test Well 3, Square Lake Test Well 1, and Fish Creek Test Well 1.

\section{INTRODUCTION}

Two recent high-profile discoveries on state lands in the Colville Delta area (Armstrong-Repsol Pikka) and the eastern National Petroleum Reserve-Alaska (ConocoPhillips Willow) include reservoirs in the Nanushuk Formation. These discoveries are in stratigraphic traps situated along lowstand shelf margins. In 2017 the U.S. Geological Survey assessed the undiscovered, but technically recoverable resources in the Nanushuk and Torok Formations in the National Petroleum Reserve in Alaska (NPR-A). They estimated mean undiscovered, technically recoverable resources of 8.7 billion barrels of oil (BBO) in conventional accumulations in the two formations and slightly over 6 BBO in the Nanushuk Formation alone (U.S. Geological Survey, 2017). In the northern NPR-A undiscovered resources are likely to reside in stratigraphic traps, whereas in the foothills belt to the south, structural traps and combination structural and stratigraphic traps are likely to be important. The size of the new discoveries and estimated volume of undiscovered resources suggest the Nanushuk Formation will remain an attractive exploration target for some time.

The Nanushuk Formation is a Lower Cretaceous (Albian - Cenomanian) fluvial-deltaicshelf succession corresponding to prominent topset reflectors on seismic sections (figs. 1 and 2).

'Alaska Division of Geological \& Geophysical Surveys, 3354 College Road, Fairbanks, AK 99709

${ }^{2}$ Alaska Division of Oil and Gas, 550 W. 7th Ave., Suite 1100, Anchorage, AK 99501 


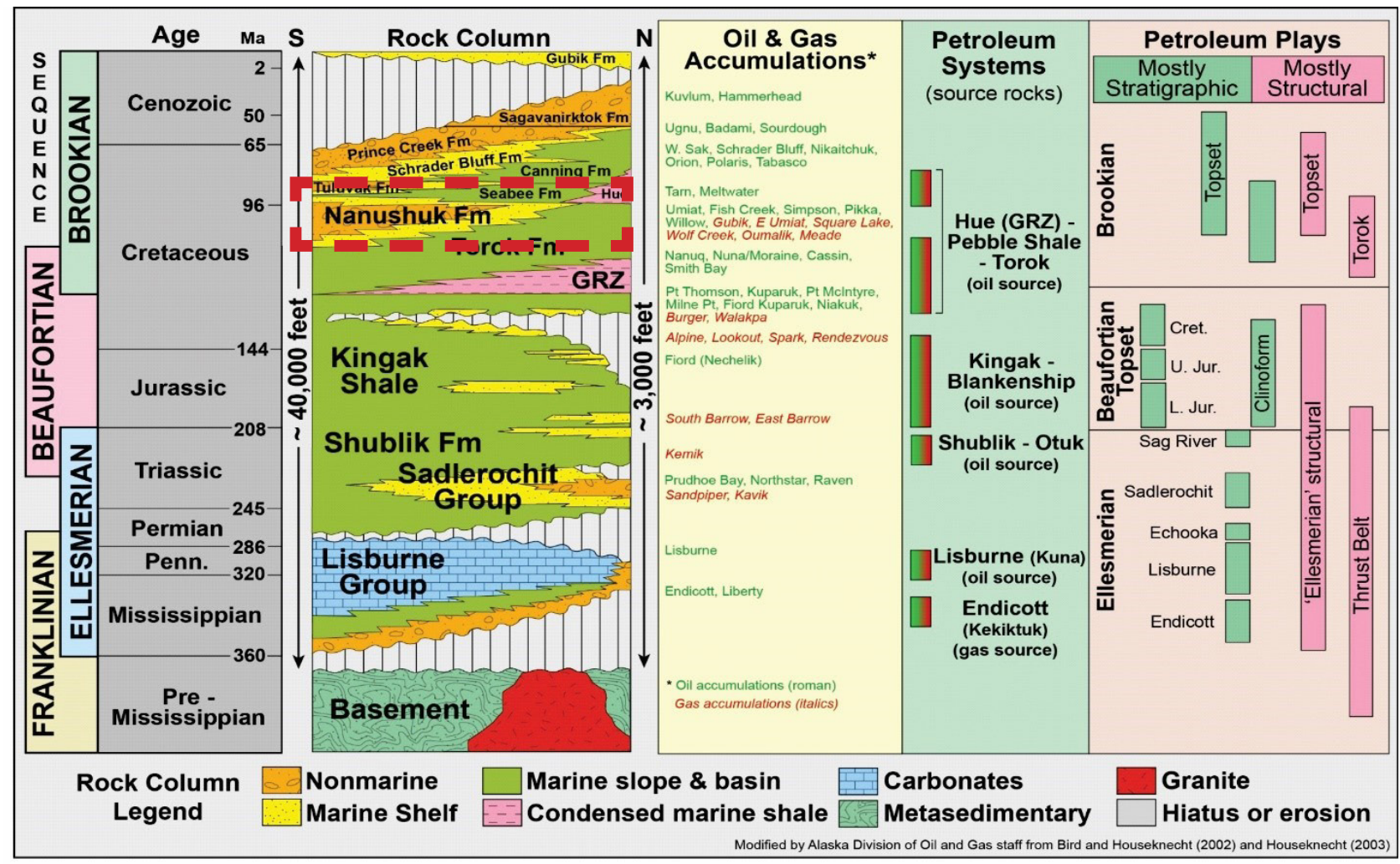

Figure 1. North Slope stratigraphy and petroleum systems. Stratigraphic focus of core workshop is shown with dashed red rectangle. After Bird and Houseknecht (2002) and Houseknecht (2003).

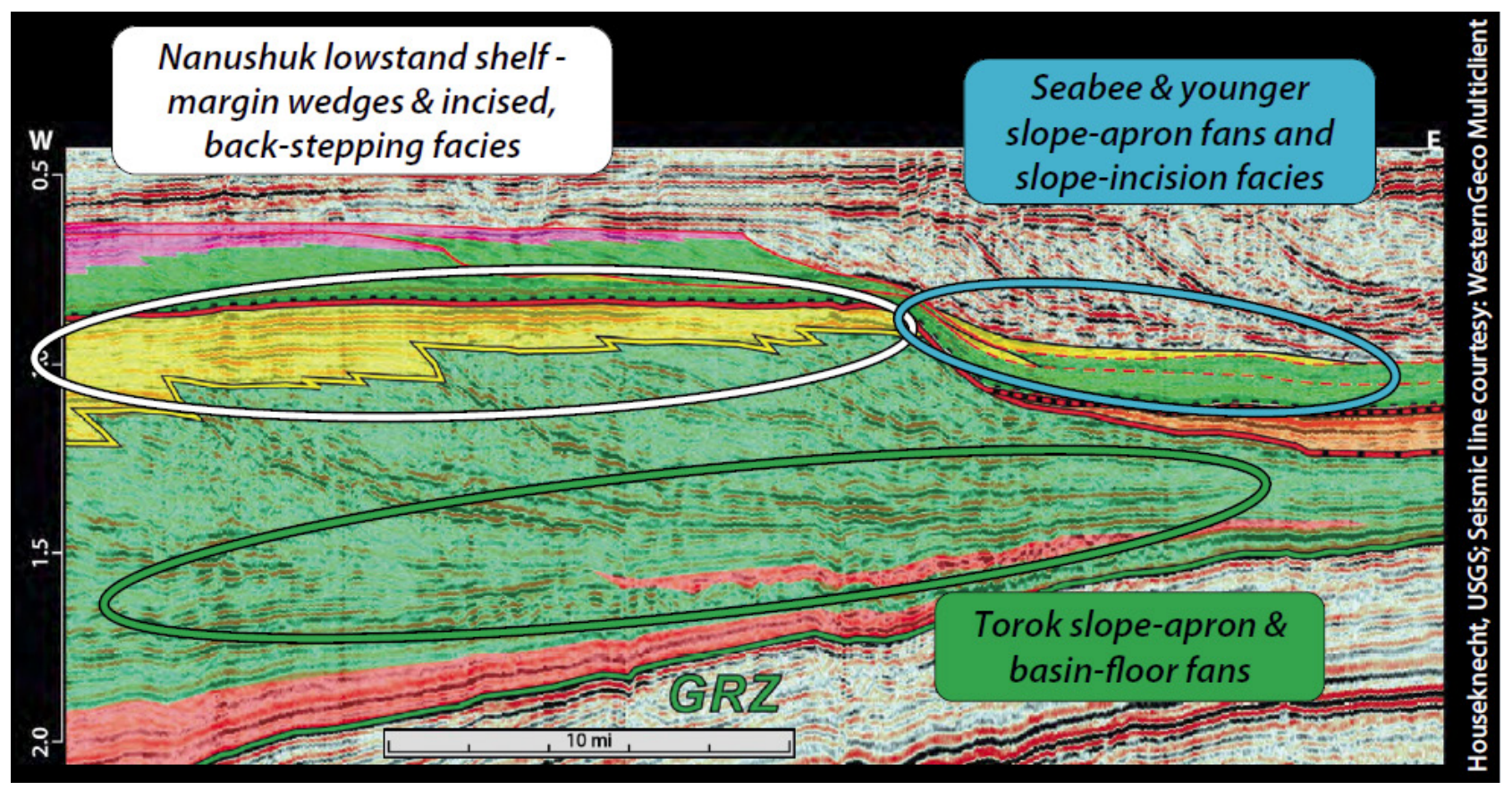

Figure 2. Seismic section showing Brookian stratigraphy and play concepts. Courtesy of David Houseknecht (U.S. Geological Survey). 


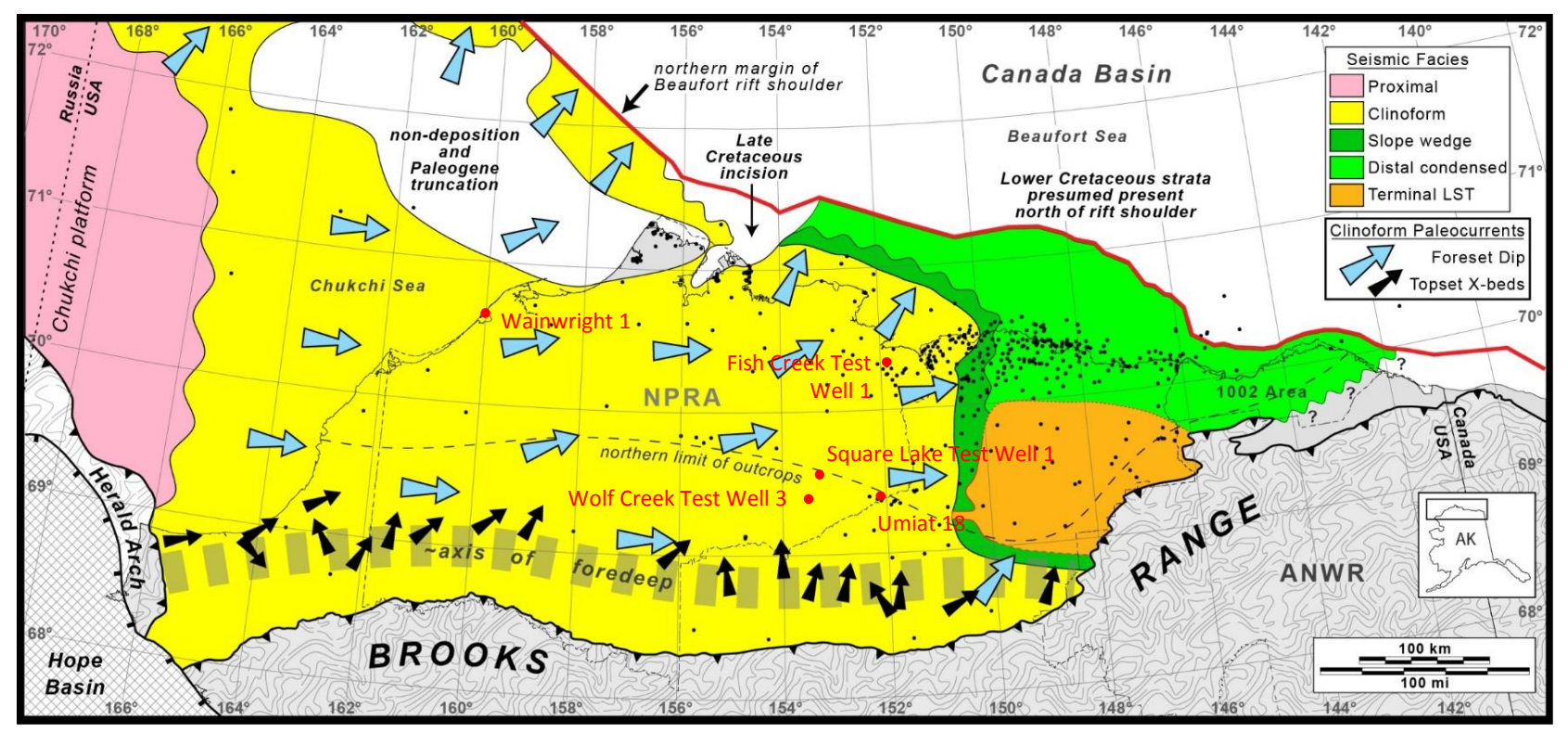

Figure 3. Paleogeography associated with the terminal Nanushuk lowstand shelf margin (Cenomanian). Wells featured in this workshop are shown in red. After David Houseknecht (U.S. Geological Survey).

Nanushuk strata grade seaward to slope and basinal facies in the coeval Torok Formation (fig. 2) (Bird and Andrews, 1979; Houseknecht and Schenk, 2001; Houseknecht, 2018). Genetically related depositional systems comprising these formations prograded eastward from source areas in eastern Chukotka and the Herald arch, down the axis of the Colville foreland basin, and northward from the ancestral Brooks Range, filling the western two-thirds of the basin by mid-Cenomanian time (fig. 3)(Molenaar, 1985, 1988; Houseknecht, 2018).

During times of major relative sea level fall, shelf-wide erosion surfaces truncated topsets and upper slope deposits near shelf margins, and juxtaposed shore zone and shallow marine facies of the Nanushuk on upper slope facies of the Torok (fig. 2). The Nanushuk reservoirs at Pikka and Willow are inferred to have been deposited during relative sea level lowstands. This workshop does not focus exclusively on lowstand deposits, but includes core from a range of depositional settings, including facies that may be important in lowstand shelf-edge positions. A candidate sequence boundary and associated lowstand deposits are identified in cores from Square Lake Test Well 1 and are featured in this workshop (1,886 to $1,841 \mathrm{feet})$. The Nanushuk includes many sand bodies deposited in a range of delta plain, delta front, and shoreface settings that represent attractive reservoir targets (fig. 4).

Between 1944 and 1953 the U.S. Navy conducted a program to evaluate the petroleum potential of the National Petroleum Reserve in Alaska (NPR-A), referred to at that time as the Naval Petroleum Reserve No. 4. As part of this program a series of test wells were drilled by Arctic Contractors, including Fish Creek Test Well 1, Square Lake Test Well 1, and Wolf Creek Test Wells 1, 2, and 3. The Fish Creek Test Well 1 was drilled (spudded May 17, 1949) 1 1/2 miles northeast of an oil seep to determine the stratigraphy beneath the northeastern part of the NPR-A and to test for hydrocarbons in a large gravity anomaly (Robinson and Collins, 1959). The Square Lake (spudded January 26, 1952) and Wolf Creek (spudded August 20, 1952) wells drilled anticlinal structures and both encountered small gas accumulations (Collins, 1959). Modern log suites are not available for these wells; only SP and resistivity logs were run, which are included in the following section. These logs are taken from Nelson and Kibler (2001). 


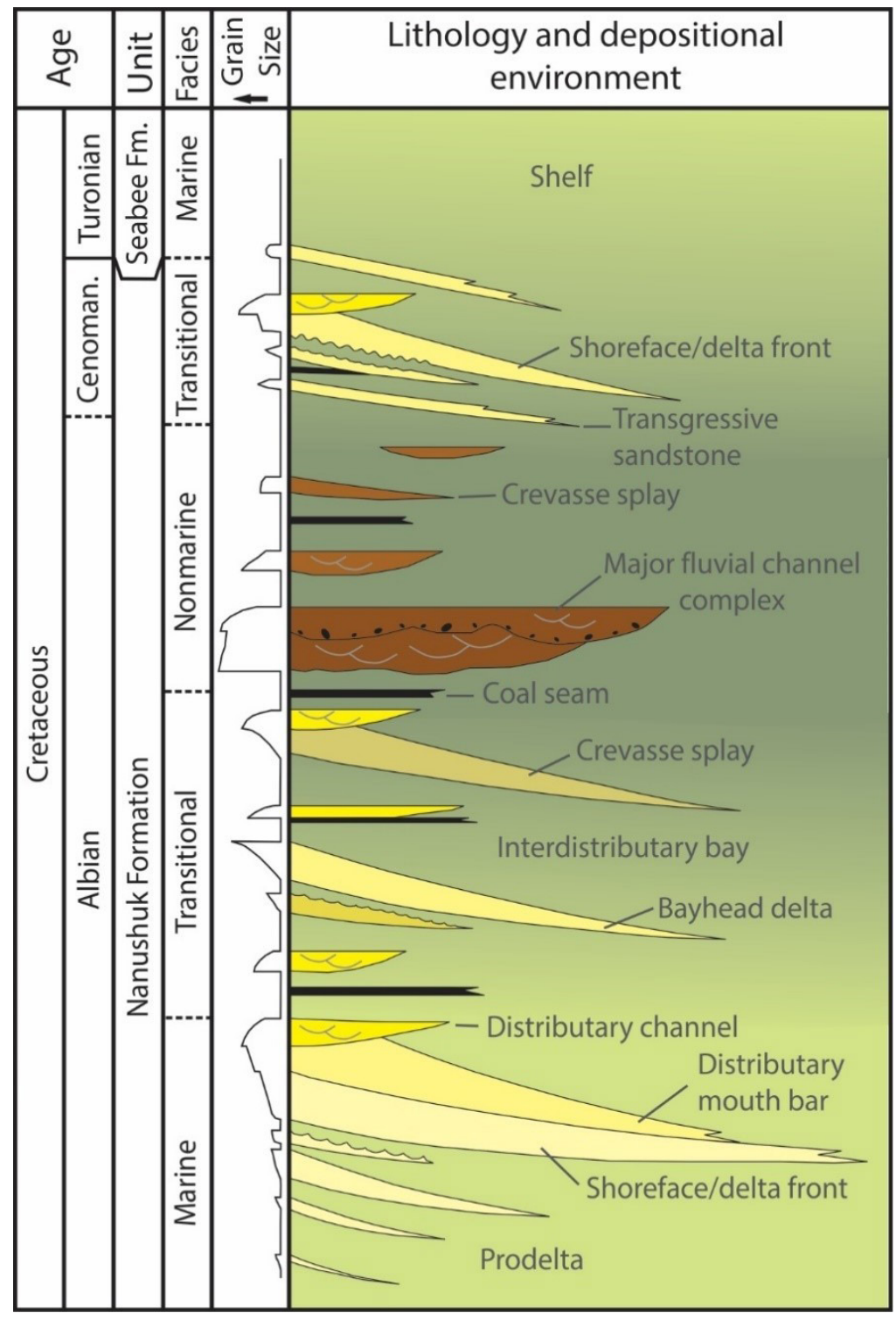

Figure 4. Facies associations in the Nanushuk Formation. After LePain and others (2009), based on Huffman and others (1988). The Nanushuk is portrayed schematically as a regressive succession capped by thinner transgressive deposits in its uppermost part. Seismic and outcrop data demonstrate the existence of lowstand erosion surfaces across which shallow and marginal-marine facies are juxtaposed on deeper water facies.

After well site operations were completed, the Fish Creek, Square Lake, and Wolf Creek cores were shipped to Fairbanks for analysis and many were ultimately slabbed. Of the slabbed cores, one half is now archived at the U.S. Geological Survey's Core Research Center (CRC) in Lakewood, Colorado, and the other half is archived at the Alaska Division of Geological \& Geophysical Survey's (DGGS) Geologic Materials Center (GMC) in Anchorage, Alaska. While the GMC splits are featured in this workshop, the detailed core descriptions shown are based on the CRC splits, which were described in detail in 2000-01 in preparation for the NPRA core workshop organized by David Houseknecht and held in conjunction with the 2001 AAPG ACE in Denver (Houseknecht, 2001). Information on cuttings between cored intervals, core numbers, and core recovery are shown on the core descriptions in blue font. This information is from Collins (1959) and Robinson and Collins (1959).

The cored intervals in Wolf Creek Test Well 3 and Square Lake Test Well 1 each include a progradational stack of sandier-upward parasequences comprised of mudstone deposited in distal settings (shelf, offshore-transition, and prodelta) at their base that grade upward to sandstone deposited in delta-front/shoreface settings at their top. We describe them as delta-front/shoreface 
because they include unmistakable evidence for a deltaic influence, mainly in the abundance of massive sandstones, horizontal plane-parallel laminated sandstones (upper flow regime), and abundant small plant fragments ("coffee grounds") scattered along bed and parting surfaces (Bhattacharya, 2006), and abundant features commonly found in storm-wave modified shoreface successions (McCubbin, 1981; Reinson, 1984; Walker and Plint, 1992; Clifton, 2006). In wavemodified and wave-dominated deltas, sand is redistributed by waves and associated longshore currents along strike from the distributary channel mouth, building shoreline successions that are similar to non-deltaic shorefaces (Bhattacharya, 2006; Hampson and Howell, 2005), with the notable exception that plant fragments are common to abundant and the diversity and abundance of trace fossil assembalges are typically reduced in deltaic settings (MacEachern and others, 2005). When waves approach the delta at an oblique angle to the overall shoreline trend, the distributary channel and mouthbar act like a groyne causing sand to accumulate on the updrift side of the delta lobe creating an asymmetric delta (Bhattacharya and Giosan, 2003). In these situations, the delta-front updrift from the distributary mouth is essentially a shoreface (Bhattacharya, 2006). Parasequences resembling truncated shoreface successions are common in these cores.

In storm-wave influenced shallow marine settings, including delta-front and shoreface environments, powerful storm waves leave their mark in the form of hummocky and swaley cross-stratification (HCS and SCS, respectively), and associated features, including mudstone rip-up clast lags overlying scour surfaces and gutter casts. These features are commonly observed in the Nanushuk Formation in outcrop and tentatively recognized in cores from Wolf Creek Test Well 3 and Square Lake Test Well 1 (LePain and Kirkham, 2001; LePain and others, 2009). HCS and SCS are typically large-scale structures with wavelengths (crest-to-crest/swale-to-swale) ranging from a few feet to over 8 feet (Walker, 1984) (fig. 5). These structures are relatively easy to identify in outcrop but can be challenging to recognize in core. Their presence is inferred by planar laminations that dip less than 10 degrees (commonly only a few degrees), abrupt or gradual changes in laminae dip direction up and/or down the core over short stratigraphic distances (less than a foot to few feet), and subtle low-angle laminae truncation below low-angle or flat surfaces that are overlain by flat laminae or laminae dipping at a low angle in the opposite direction (fig. 5). In addition to abundant wave-generated structures, outcrops and cores indicate that tides were locally important in shaping Nanushuk shore zone and shallow marine settings (LePain and others, 2009). Evidence of tidal processes in the cores include thin mudstone drapes separating sandstone laminae forming thin, rhythmically layered successions. Tide-dominated settings have not been recognized in outcrop or in the featured cores, but it would not be surprising to see greater tidal influence locally, such as in embayed areas of the Nanushuk coastline (including the flooded seaward ends of incised paleovalleys).

Each parasequence represented in these cores records a single episode of shoreline progradation and the abrupt change from sandstone to mudstone, or thinly interbedded sandstone and mudstone, marks the end of a progradational episode and abandonment of a delta lobe and associated shorefaces. As a lobe is transgressed, wave-ravinement processes remove the uppermost part of the progradational succession, leaving a top-truncated sandier-upward parasequence in which the upper 15 to 35 feet is missing due to wave ravinement (Bruhn, 1961; Bhattacharya, 2006). Most of the parasequences cored in these two wells are top-truncated. The mud-dominated lithologies overlying these sandy successions represent potential reservoir seals. In some parasequences the abrupt change up-section from sandstone to mudstone is part of a progradational succession in which little or no sand was removed by wave erosion, and the transition represents the migration of bayfill-lagoonal environments over the top of the underlying 


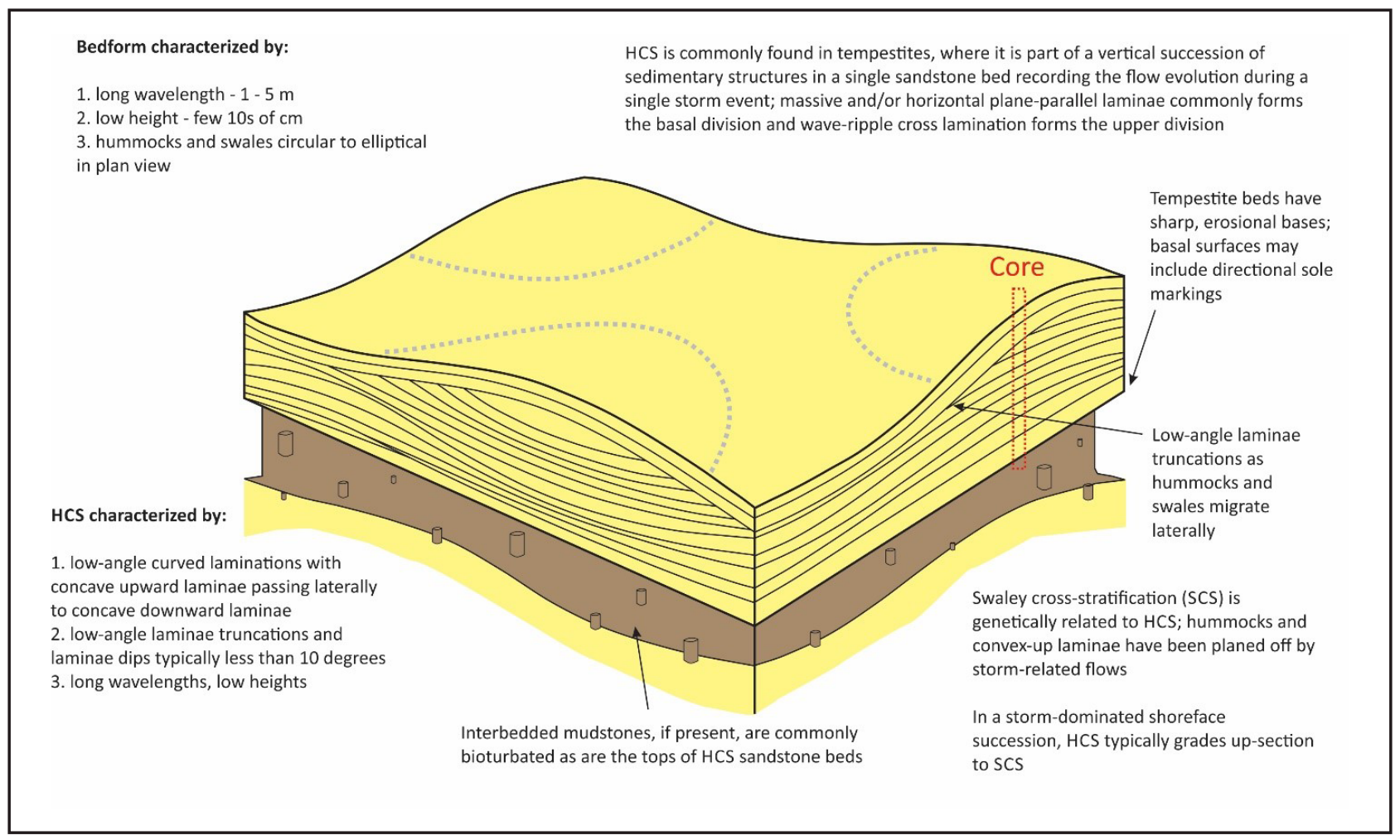

Figure 5. Schematic cartoon illustrating key features of hummocky cross-stratification. Modified from Walker (1984).

shoreline sand body in accordance with Walther's Law. In the Wolf Creek Test Well 3, the change from sandstone at 1,977 feet and 1,887 feet to dominantly mudstone above are interpreted as the deposits resulting from seaward migration of bayfill environments over sandy shore zone environments.

Wainwright 1 was drilled by the U.S. Geological Survey in the Village of Wainwright to evaluate the coalbed gas potential of the Nanushuk Formation (Clark, 2014). Continuous core was cut from 75 feet to 1,605 feet. The resulting well was logged using the survey's gamma-ray logging tool. The core was slabbed with half shipped to the CRC and half archived at the GMC. Prior to shipping the USGS split to the CRC, plugs were cut for reservoir quality analysis, and the core was described in detail (Decker and LePain, 2016; LePain and Decker, 2016; Helmold, 2016). This core is an outstanding, nearly uninterrupted 1,530-foot-thick record of lower delta to upper delta plain facies. Trace fossils in the lower part of the cored succession suggest deposition in saline waters (brackish) and a marine influence is recognized for approximately 1,340 feet. A relatively diverse marine trace fauna is recognized at several depths, suggesting surface waters at these depositional sites had near-normal marine salinities. The possible occurrence of hummocky cross-stratification and a gutter cast in the lower 25 feet of the cored interval suggests the possibility of deposition at the seaward end of an interdistributary bay or in an open-marine prodelta setting. Of course we do not know what facies are immediately below the base of the cored interval, but the lower 25 feet may represent the record of an interdeltaic segment of the coastline - lower energy (overall), muddy shoreline between deltaic headlands.

Umiat 18 was drilled by Linc Energy, Inc., on the south limb of Umiat anticline (spudded March $10,2013)$ to confirm the presence of recoverable hydrocarbons. Continuous core was cut in the Nanushuk Formation from a measured depth of 710 feet to 1,014.6 feet. The well was subsequently 


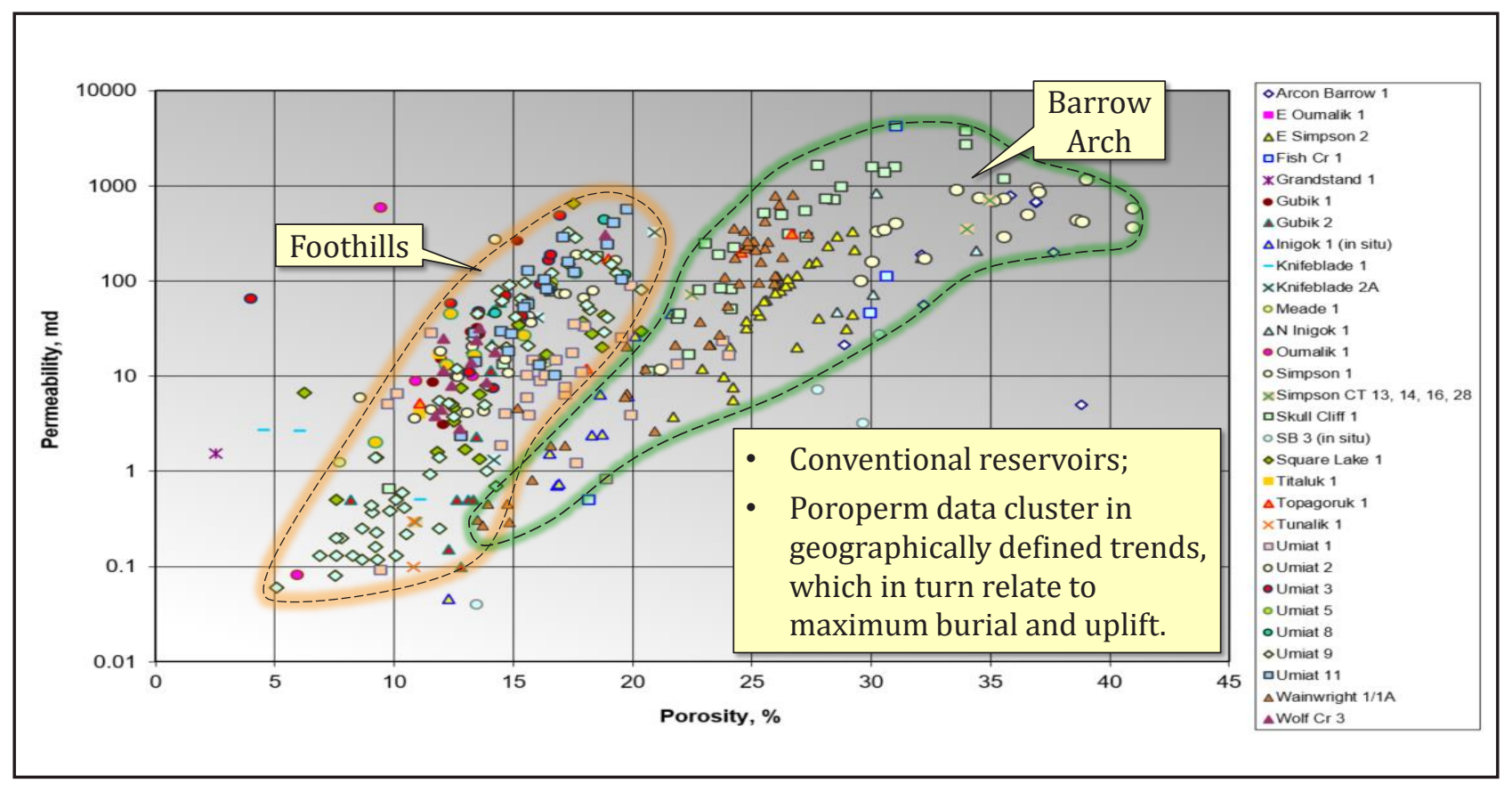

Figure 6. Porosity vs. permeability plot for sandstones in the Nanushuk in selected wells (Decker, 2018).

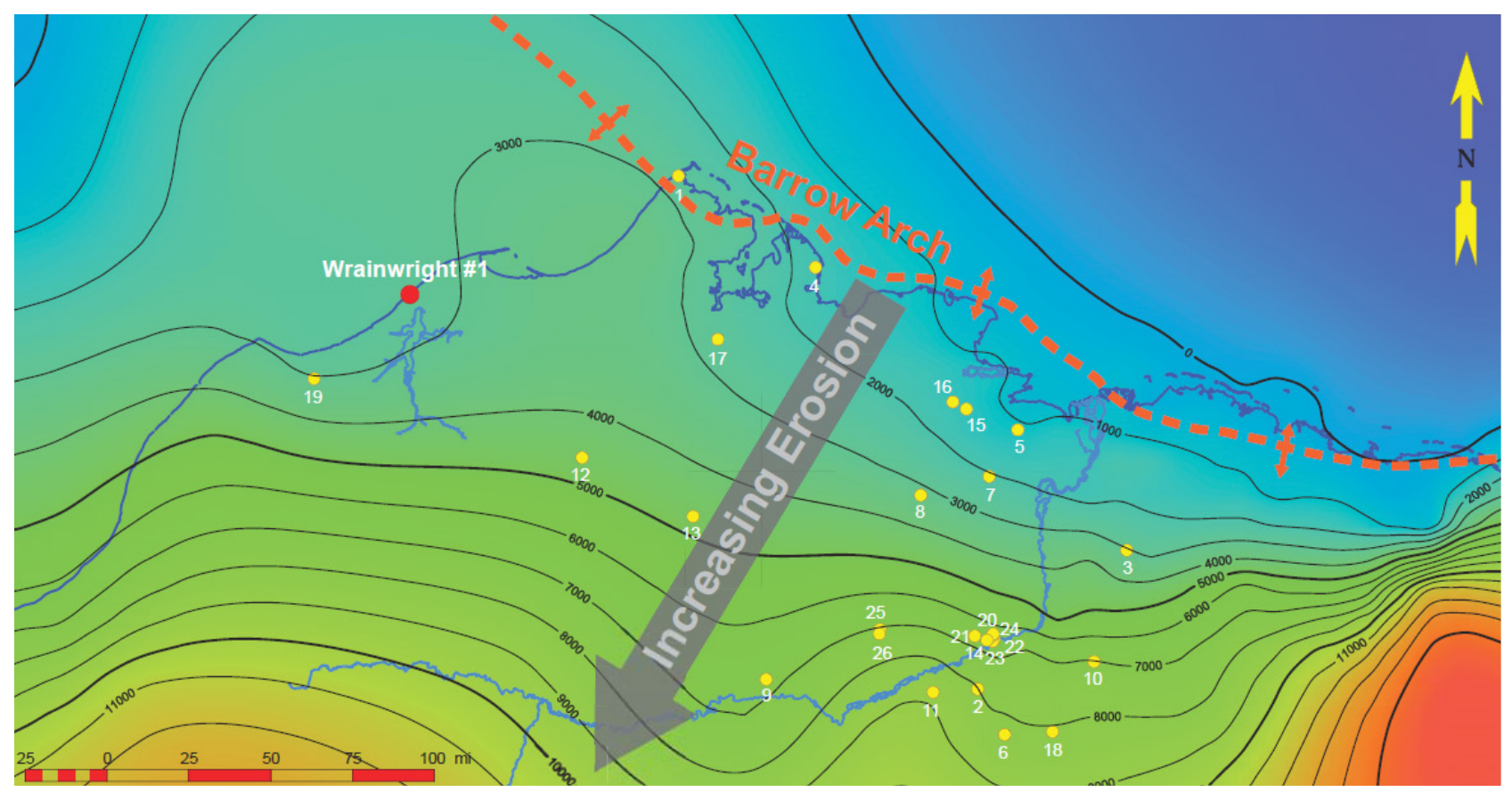

Figure 7. Contoured map of the central North Slope showing estimates of the amount (in feet) of Brookian strata removed by erosion (Helmold, 2016). Contours were generated using data from Burns and others (2005). 


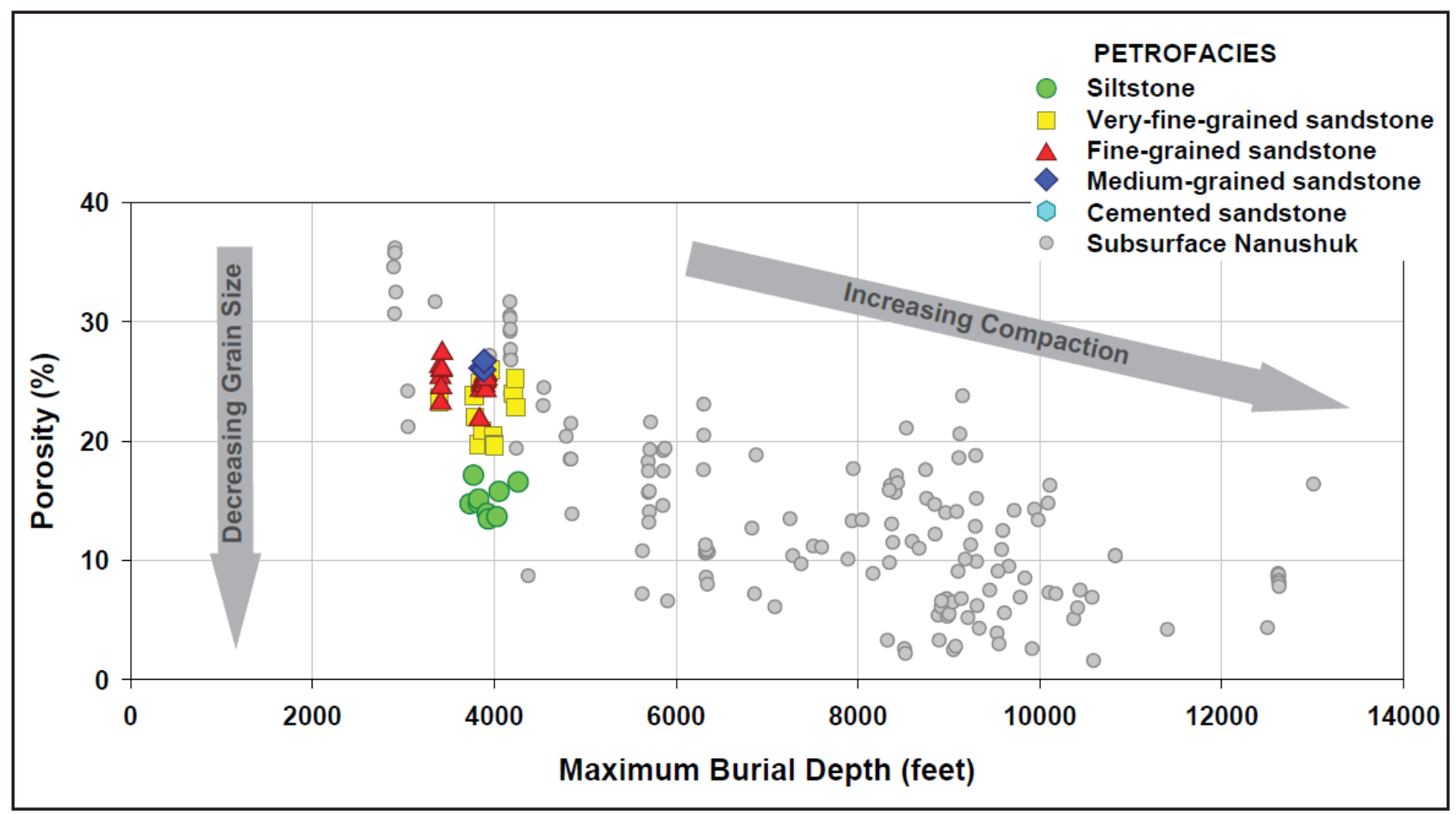

Figure 8. Cross plot of porosity versus maximum burial depth (Dmax) for the Wainwright 1 well and regional Nanushuk siltstones and sandstones. The Wainwright samples have Dmax values ranging from 2,944 to 4,263 feet, while most of the regional Nansuhuk samples were buried to greater depths (Dmax >6,000 feet) (Helmold, 2016).

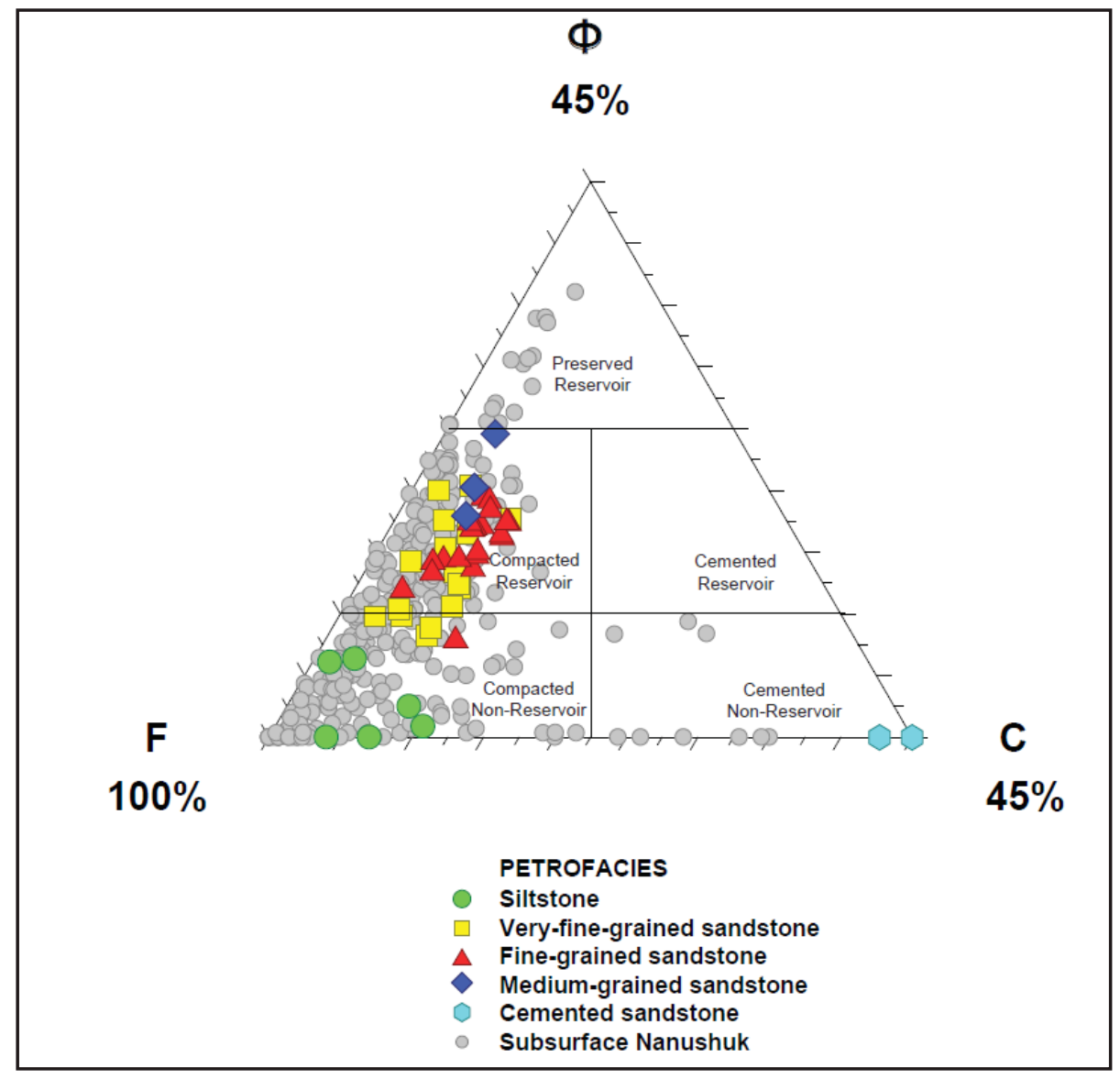

Figure 9. Porosity-Framework-Cement ternary diagram showing reservoir quality of the Wainwright and regional Nanushuk siltstones and sandstones (Helmold, 2016). 
logged by Schlumberger (triple combo) and the core was slabbed. Linc donated the core to the GMC in December 2014 and DGGS described it in August 2018. The cored interval in Umiat 18 includes proximal prodelta, delta front, and possibly the fill of the distal part of a distributary channel.

In Fish Creek Test Well 1 the cored interval in the Nanushuk Formation is comprised of finegrained facies deposited in a distal shelf setting. Small carbonaceous plant fragments are abundant on many bed and parting surfaces. Several cores include siltstones and very fine-grained sandstones that are heavily oil-stained.

The locations of wells featured in this workshop are shown in figure 3 . The composition and reservoir quality characteristics of Nanushuk sandstones are summarized in figures 6-9.

Core descriptions, wireline logs, seismic sections, and selected thin-section photomicrographs are included for each of the featured cores and organized by well in the following section. A seismic section through Umiat 18 was not available when these notes were compiled. A list of questions to consider, and features to look for, are included at the back of these notes. Note: For hardcopies, the wireline logs and core descriptions are best printed on 11-inch by 17 -inch paper.

\section{FEATURED WELLS AND CORED INTERVALS}

\section{WAINWRIGHT 1}

Depth ranges: 1,542 to 1,467 feet; 1,177 to 900 feet; 705 to 557 feet

Interpreted depositional elements: distributary channel, interdistributary bay, crevasse/bayhead delta, splay sand sheet.

\section{WOLF CREEK TEST WELL 3}

Depth range: 2,195 to 1,645 feet [cores 26 to 8 ]

Interpreted depositional elements: shelf, shoreface/delta-front, distributary mouth bar, interdistributary bay.

\section{SQUARE LAKE TEST WELL 1}

Depth ranges: 3,987 to 3,825 feet [cores 67 to 61 ]; 2,035 to 1,841 feet [cores 37 to 31 ]; 1,776 to 1,657 feet [cores 29 to 23]

Interpreted depositional elements: shoreface/delta-front, distributary mouth bar, interdistributary bay, crevasse delta(?). A candidate sequence boundary and associated lowstand deposits are identified in cores 33 through 31.

\section{UMIAT 18}

Depth range: 868 to 761 feet [lower part of core 1, core 2, and upper part of core 3]

Interpreted depositional elements: proximal prodelta, distributary mouthbar, distal distributary channel(?).

\section{FISH CREEK TEST WELL 1}

Depth range: 3,386 to 2,700 [cores 38 to 18 ]

Interpreted depositional elements: distal shelf.

\section{REFERENCES}


Bhattacharya, J.P., 2006, Deltas, in Posamentier, H.W., and Walker, R.G., eds., Facies Models Revisited: SEPM Special Publication 84, p. 237-292.

Bhattacharya, J.P., and Giosan, L., 2003, Wave-influenced deltas: geomorphological implications for facies reconstruction: Sedimentology, v. 50, p. 187-210.

Bird, K.J., and Houseknecht, D.W., 2002, U.S. Geological Survey 2002 petroleum resource assessment of the National Petroleum Reserve in Alaska (NPRA): U.S. Geological Survey Fact Sheet 045-02. http://pubs.usgs.gov/fs/2002/fs045-02/fs045-02.pdf

Bruun, P., 1961, Sea-level rise as cause of shore erosion: Proceedings of the American Society of Civil Engineers, Journal of Water and Harbors Division, v. 88, p. 117-130.

Burns, W.M., Hayba, D.O., Rowan, E.L., and Houseknecht, D.W., 2005, Estimating the amount of eroded section in a partially exhumed basin from geophysical well logs: An example from the North Slope: Studies by the U.S. Geological Survey in Alaska, 2005, U.S. Geological Survey Professional Paper 1732-D, p. 1-18.

Clark, A.C., 2014, Coalbed natural gas exploration, drilling activities, and geologic test results, 2007-2010, Wainwright, Alaska: U.S. Geological Survey Open-File Report 2014-1004, 65 p.

Clifton, H.E., 2006, Reexamination of facies models for clastic shorelines, in Posamentier, H.W., and Walker, R.G., eds., Facies Models Revisited: SEPM Special Publication 84, p. 293-397.

Collins, F.R., 1959, Test wells, Square Lake and Wolf Creek areas Alaska: U.S. Geological Survey Professional Paper 305-H, 64 p., 2 plates.

Decker, P.L., 2018, Nanushuk Formation discoveries confirm world-class exploration potential in a newly proven stratigraphic play, Alaska North Slope: Discovery Thinking Forum, AAPG ACE, Salt Lake City, UT, May, 2018.

Decker, P.L., and LePain, D.L., 2016, Subsurface relationships of Albian-Cenomanian shallow marine to nonmarine topsets of the Nanushuk Formation, northwestern NPRA, northern Alaska, in LePain, D.L., ed., Stratigraphic and reservoir quality studies of continuous core from the Wainwright \# 1 coalbed methane test well, Wainwright, Alaska: Alaska Division of Geological \& Geophysical Surveys Report of Investigation 2016-3-1, p. 1-3, 1 sheet. http://doi. org/10.14509/29655

Hampson, G.J., and Howell, J.A., 2005, Sedimentologic and geomorphic characterization of ancient wave-dominated deltaic shorelines: Upper Cretaceous Blackhawk Formation, Book Cliffs, Utah, U.S.A., in Giosan, L., and Bhattacharya, J.P., ed. River Deltas-Concepts, Models, and Examples: SEPM Special Publication 83, p. 133-154.

Helmold, K.P., 2016, Sedimentary petrology and reservoir quality of Albian-Cenomanian Nanushuk Formation sandstones, USGS Wainwright \# 1 test well, western North Slope, Alaska, in LePain, D.L., Stratigraphic and reservoir quality studies of continuous core from the Wainwright \# 1 coalbed methane test well, Wainwright, Alaska: Alaska Division of Geological \& Geophysical Surveys Report of Investigation 2016-3-3, p. 37-57. http://doi.org/10.14509/29657

Herriott, T.M., Wartes, M.A., Decker, P.L., Gillis, R.J., Shellenbaum, D.P., and Mauel, D.J., 2018, Geologic map of the Umiat-Gubik area, central North Slope, Alaska: Alaska Division of Geological \& Geophysical Surveys Report of Investigations, 55 p., 1 sheet, 1:63,360.

Houseknecht, D.W., 2003, Brookian stratigraphic plays in the National Petroleum Reserve-Alaska (NPRA): U.S. Geological Survey Open-File Report 03-039.

Houseknecht, D.W., 2001, NPRA Core Workshop: Petroleum Plays and Systems in the National Petroleum Reserve-Alaska: SEPM Core Workshop No. 21, Denver, CO, June 7-8.

Huffman, A.C., Ahlbrandt, T.S., and Bartsch-Winkler, S., 1988, Sedimentology of the Nanushuk Group, North Slope, in Gryc, George, ed., Geology and exploration of the National Petroleum 
Reserve in Alaska, 1974 to 1982: U.S. Geological Survey Professional Paper 1399, p. 281-298.

LePain, D.L., and Decker, P.L., 2016, Lithofacies analysis of the Wainwright \#1 continuous core, western Arctic Slope, Alaska: Transition from lower to upper delta plain environments in the Albian-Cenomanian Nanushuk Formation, in LePain, D.L., ed., Stratigraphic and reservoir quality studies of continuous core from the Wainwright \#1 coalbed methane test well, Wainwright, Alaska: Alaska Division of Geological \& Geophysical Surveys Report of Investigation 2016-3-2, p. 5-35, 1 sheet. http://doi.org/10.14509/29656

LePain, D.L., McCarthy, P.J., and Kirkham, R., 2009, Sedimentology and sequence stratigraphy of the middle Albian-Cenomanian Nanushuk Formation in outcrop, central North Slope, Alaska: Alaska Division of Geological \& Geophysical Surveys Report of Investigation 2009-1 v. 2, 76 p., 1 sheet. http://doi.org/10.14509/19761

LePain, D.L., and Kirkham, R., 2001, Potential reservoir facies in the Nanushuk Formation (AlbianCenomanian), central North Slope, Alaska: Examples from outcrop and core, in Houseknecht, D.W., ed., NPRA Core Workshop: Petroleum Plays and Systems in the National Petroleum Reserve-Alaska: SEPM Core Workshop No. 21, Denver, CO, June 7-8, 2001, p. 19-36.

MacEachern, J.A., Bann, K.L., Bhattacharya, J.P., and Howell, C.D., 2005, Ichnology of deltas: organism responses to dynamic interplay of rivers, waves, storms, and tides, in Giosan, L., and Bhattacharya, J.P., ed. River Deltas-Concepts, Models, and Examples: SEPM Special Publication 83, p. 49-85.

McCubbin, D.G., 1981, Barrier-island and strand plain facies, in Scholle, P.A., and Spearing, D., eds., Sandstone Depositional Environments: AAPG Memoir 31, p. 247-279.

Mull, C.G., Houseknecht, D.W., Pessel, G.H., and Garrity, C.P., 2005, Geologic map of the Ikpikpuk River Quadrangle, Alaska: U.S. Geological Survey Scientific Investigations Map 2817-B, 1 sheet, scale $1: 250,000$.

Nelson, P.H., and Kibler, J.E., 2001, Well logs and core data from selected cored intervals, National Petroleum Reserve, Alaska: U.S. Geological Survey Open-File Report 01-167.

Reinson, G.E., 1984, Barrier island and associated strand-plain systems, in Walker, R.G., ed., Facies Models, 2nd Edition: Geoscience Canada, p. 119-140.

Walker, R.G., 1984, Shelf and shallow seas, in Walker, R.G., ed., Facies Models, 2nd Edition: Geoscience Canada, p. 141-170.

Walker, R.G., and Plint, A.G., 1992, Wave- and storm-dominated shallow marine systems, in Walker, R.G., and James, N.P., eds. Facies Model: Response to Sea Level Change: Geological Association of Canada, p. 219-238.

Robinson, F.M., and Collins, F.R., 1959, Core test, Sentinel Hill area and test well Fish Creek area, Alaska: U.S. Geological Survey Professional Paper 305-I, 39 p., 4 plates.

\section{RECOMMENDED READING}

Ahlbrandt, T.S., ed., 1979, Preliminary geologic, petrologic, and paleontologic results of the study of Nanushuk Group rocks, North Slope, Alaska: U.S. Geological Survey Circular 794, 163 p.

Bartsch-Winkler, Susan, and Huffman, A.C., Jr., 1988, Sandstone petrography of the Nanushuk Group and Torok Formation, in Gryc, George, ed., Geology and exploration of the National Petroleum Reserve in Alaska, 1974 to 1982: U.S. Geological Survey Professional Paper 1399, p. 801-831.

Decker, P.L., 2007, Brookian sequence stratigraphic correlations, Umiat Field to Milne Point Field, west-central North Slope, Alaska: Alaska Division of Geological \& Geophysical Surveys Preliminary Interpretive Report 2007-2, 19 p., 1 sheet. http://doi.org/10.14509/15758

Decker, P.L., Wilson, G.C., Watts, A.B., and Work, David, 1998, Growth-position petrified trees 
overlying thick Nanushuk Group coal, Lili Creek, Lookout Ridge Quadrangle, North Slope Alaska, in Clough, J.G., and Larson, Frank, eds., Short notes on Alaska geology 1997: Alaska Division of Geological \& Geophysical Surveys Professional Report 118E, p. 63-70. http://doi. org/10.14509/2332

Decker, P.L., Wartes, M.A., Wallace, W.K., Houseknecht, D.W., Schenk, C.J., Gillis, R.J., and Mongrain, Jacob, 2008, Stratigraphic and structural investigations in the Ivishak River and Gilead Creek areas: Progress during 2007, in Wartes, M.A., and Decker, P.L., eds., Preliminary results of recent geologic field investigations in the Brooks Range Foothills and North Slope, Alaska: Alaska Division of Geological \& Geophysical Surveys Preliminary Interpretive Report 2008-1F, p. 55-83, 1 sheet. http://doi.org/10.14509/16089

Finzel, E.S., 2004, Architectural analysis and fold geometry of syntectonic fluvial conglomerate in the Nanushuk Formation, Brooks Range foothills, Alaska: University of Alaska Fairbanks, M.S. thesis, 230 p., illust., maps.

Harris, E.E., Mull, C.G., Reifenstuhl, R.R., and Montayne, Simone, 2002, Geologic map of the Dalton Highway (Atigun Gorge to Slope Mountain) area, southern Arctic Foothills, Alaska: Alaska Division of Geological \& Geophysical Surveys Preliminary Interpretive Report 2002-2, 1 sheet, scale 1:63,360. http://doi.org/10.14509/2867

Harris, E.E., Delaney, P.R., Mull, C.G., LePain, D.L., and Burns, P.C., 2009, Geologic map of the Kanayut River area, Chandler Lake Quadrangle, Alaska: Alaska Division of Geological \& Geophysical Surveys Preliminary Interpretive Report 2009-7, 1 sheet, scale 1:63,360. http://doi. org/10.14509/19781

Houseknecht, D.W., 2018, Petroleum-systems framework of significant new oil discoveries in a giant Cretaceous clinothem in Arctic Alaska: AAPG Bulletin, in press.

Houseknecht, D.W., and Schenk, C.J., 2001, Depositional sequences and facies in the Torok Formation, National Petroleum Reserve-Alaska (NPRA), in Houseknecht, D.W., ed., NPRA Core Workshop: Petroleum Plays and Systems in the National Petroleum Reserve-Alaska: SEPM Core Workshop No. 21, Denver, CO, June 7-8, 2001, p. 179.

Houseknecht, D.W., and Schenk, C.J., 2005, Sedimentology and sequence stratigraphy of the Cretaceous Nanushuk, Seabee, and Tuluvak Formations exposed on Umiat Mountain, northcentral Alaska, in Haeussler, P.J., and Galloway, J.P., eds., Studies by the U.S. Geological Survey in Alaska, 2004: U.S. Geological Survey Professional Paper 1709-B.

Houseknecht, D.W., Bird, K.J., and Schenk, C.J., 2008, Seismic analysis of clinoform depositional sequences and shelf-margin trajectories in Lower Cretaceous (Albian) strata, Alaska North Slope: Basin Research, http://doi.org/10.1111/j.1365-2117.2008.00392.X

Huffman, A.C., Jr., 1989, The Nanushuk Group, in Mull, C.G., and Adams, K.E., eds., Bedrock geology of the eastern Koyukuk basin, central Brooks Range, and east-central Arctic Slope along the Dalton Highway, Yukon River to Prudhoe Bay, Alaska, Volume 2: Alaska Division of Geological \& Geophysical Surveys Guidebook 7-21, p. 303-309. http://doi.org/10.14509/24135

Huffman, A.C., Jr., Ahlbrandt, T.S., and Bartsch-Winkler, Susan, 1988, Sedimentology of the Nanushuk Group, North Slope, in Gryc, George, ed., Geology and exploration of the National Petroleum Reserve in Alaska, 1974 to 1982: U.S. Geological Survey Professional Paper 1399, p. 281-298.

Johnsson, M.J., and Sokol, N.K., 2000, Stratigraphic variation in petrographic composition of Nanushuk Group sandstones at Slope Mountain, North Slope, Alaska, in Kelley, K.D., and Gough, L.P., eds., Geologic studies in Alaska by the U. S. Geological Survey, 1998: U.S. Geological Survey Professional Paper 1615, p. 83-100. 
LePain, D.L., and Kirkham, R., 2001, Potential reservoir facies in the Nanushuk Formation (Albian-Cenomanian), central North Slope, Alaska: Examples from outcrop and core, in D. W. Houseknecht, ed., NPRA core workshop: Petroleum plays and systems in the National Petroleum Reserve in Alaska: SEPM Core Workshop 21, p. 19-36.

LePain, D.L., Decker, P.L., and Wartes, M.A., 2008, Measured sections and preliminary interpretations of the Nanushuk Formation exposed along the Colville River near the confluences with the Awuna and Killik rivers, in Wartes, M.A., and Decker, P.L., eds., Preliminary results of recent geologic field investigations in the Brooks Range Foothills and North Slope, Alaska: Alaska Division of Geological \& Geophysical Surveys Preliminary Interpretive Report 2008-1D, p. 41-45, 4 sheets. http://doi.org/10.14509/16088

McCarthy, P.J., 2003, Alluvial facies and paleosols in the Cretaceous Nanushuk formation, Kanayut River, North Slope, Alaska, Preliminary results from the 2001 field season: Alaska Division of Geological \& Geophysical Surveys Preliminary Interpretive Report 2003-1, 19 p. http://doi. org/10.14509/2920

Molenaar, C.M., 1982, Umiat field, an oil accumulation in a thrust-faulted anticline, North Slope of Alaska: Rocky Mountain Association of Geologists, p. 537-548.

Molenaar, C.M., 1985, Subsurface correlations and depositional history of the Nanushuk Group and related strata, North Slope, Alaska, in Huffman, A.C., Jr., ed., Geology of the Nanushuk Group and related rocks, North Slope, Alaska: U.S. Geological Survey Bulletin 1614, p. 37-59.

Molenaar, C.M., 1988, Depositional history and seismic stratigraphy of Lower Cretaceous rocks in the National Petroleum Reserve in Alaska and adjacent areas, in Gryc, G., ed., Geology and exploration of the National Petroleum Reserve in Alaska, 1974 to 1982, U.S. Geological Survey Professional Paper 1399, p. 593-621.

Mull, C.G., 1979, Nanushuk Group deposition and the late Mesozoic structural evolution of the central and western Brooks Range and Arctic Slope, in Ahlbrandt, T.S., ed., Preliminary geologic, petrologic, and paleontologic results of the study of Nanushuk Group rocks, North Slope, Alaska: U.S. Geological Survey Circular 794, p. 5-13.

Mull, C.G., Houseknecht, D.W., and Bird, K.J., 2003, Revised Cretaceous and Tertiary Stratigraphic Nomenclature in the Colville basin, Northern Alaska: U.S. Geological Survey Professional Paper 1673.

Mull, C.G., Houseknecht, D.W., Pessel, G.H., and Garrity, C.P., 2004, Geologic map of the Umiat Quadrangle, Alaska: U.S. Geological Survey Scientific Investigations Map 2817-A, 1 sheet, scale $1: 250,000$.

Mull, C.G., Houseknecht, D.W., Pessel, G.H., and Garrity, C.P., 2006, Geologic map of the Lookout Ridge Quadrangle, Alaska: U.S. Geological Survey Scientific Investigations Map 2817-C, 1 sheet, scale 1:250,000.

Mull, C.G., Houseknecht, D.W., Pessel, G.H., and Garrity, C.P., 2006, Geologic map of the Utukok River Quadrangle, Alaska: U.S. Geological Survey Scientific Investigations Map 2817-D, 1 sheet, scale $1: 250,000$.

Mull, C.G., Harris, E.E., Delaney, P.R., and Swenson, R.F., 2009, Geology of the Cobblestone CreekMay Creek area, east-central Brooks Range Foothills, Alaska: Alaska Division of Geological \& Geophysical Surveys Preliminary Interpretive Report 2009-5, 40 p., 1 sheet, scale 1:63,360. http:// doi.org/10.14509/19661

Pasternack, Ira, 1981, Depositional factors affecting the reservoir potential of the lower Cretaceous Nanushuk Group, northwestern Alaska: Golden, Colorado, Colorado School of Mines, M.S. thesis, 205 p., illust., map. 
Peapples, P.R., Wallace, W.K., Wartes, M.A., Swenson, R.F., Mull, C.G., Dumoulin, J.A., Harris, E.E., Finzel, E.S., Reifenstuhl, R.R., and Loveland, A.M., 2007, Geologic map of the Siksikpuk River area, Chandler Lake Quadrangle, Alaska: Alaska Division of Geological \& Geophysical Surveys Preliminary Interpretive Report 2007-1, 1 sheet, scale 1:63,360. http://doi.org/10.14509/15757

Shimer, G.T., McCarthy, P.J., and Hanks, C.J., 2014, Sedimentology, stratigraphy, and reservoir properties of an unconventional, shallow, frozen petroleum reservoir in the Cretaceous Nanushuk Formation at Umiat Field, North Slope, Alaska: AAPG Bulletin, v. 98, p. 631-661.

Wartes, M.A., 2008, Evaluation of stratigraphic continuity between the Fortress Mountain and Nanushuk Formations in the central Brooks Range foothills--Are they partly correlative?, in Wartes, M.A., and Decker, P.L., eds., Preliminary results of recent geologic field investigations in the Brooks Range Foothills and North Slope, Alaska: Alaska Division of Geological \& Geophysical Surveys Preliminary Interpretive Report 2008-1C, p. 25-39. http://doi.org/10.14509/16087

Wartes, M.A., and Decker, P.L., eds., 2008, Preliminary results of recent geologic field investigations in the Brooks Range Foothills and North Slope, Alaska: Alaska Division of Geological \& Geophysical Surveys Preliminary Interpretive Report 2008-1, 206 p. http://doi.org/10.14509/16083 


\section{Core}

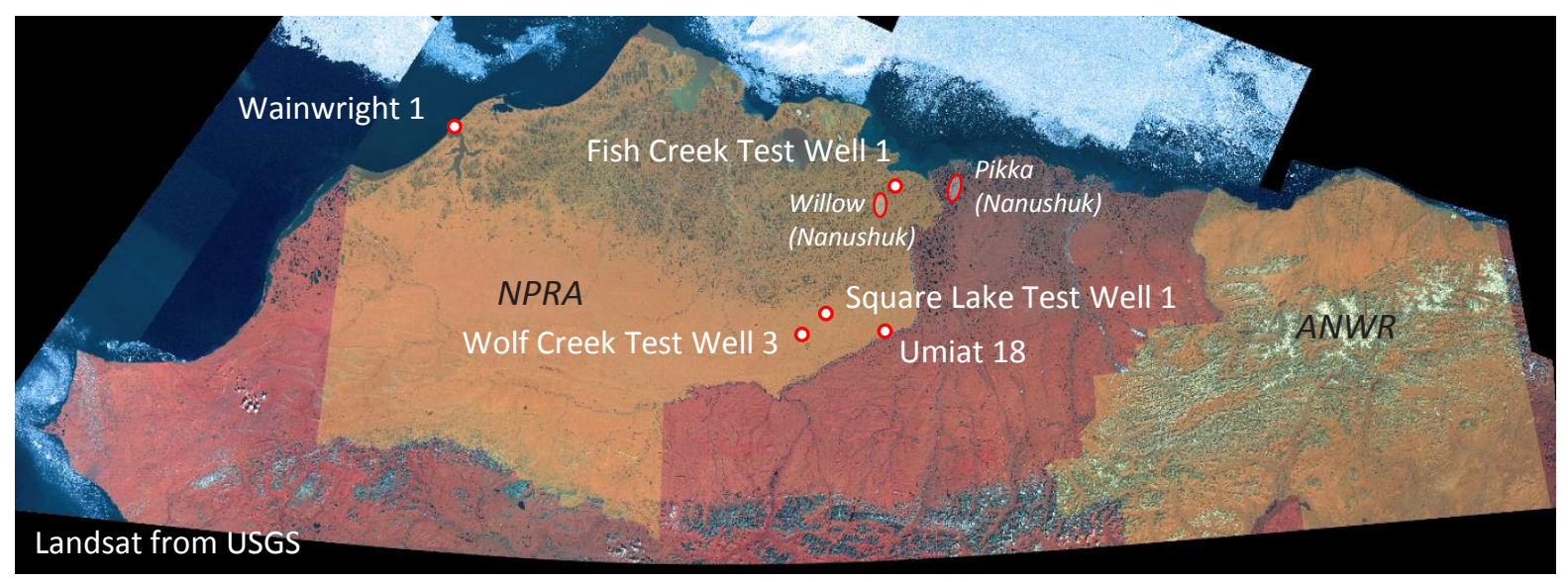

Wireline logs for Wolf Creek Test Well 3, Square Lake Test Well 1, and Fish Creek Test Well 1 are from Nelson and Kibler (2001). Text in blue font on these core descriptions are from Collins (1959) and Robinson and Collins (1959). Wireline logs for Umiat 18 are available from the Alaska Oil \& Gas Conservation Commission. 


\section{Wainwright 1}

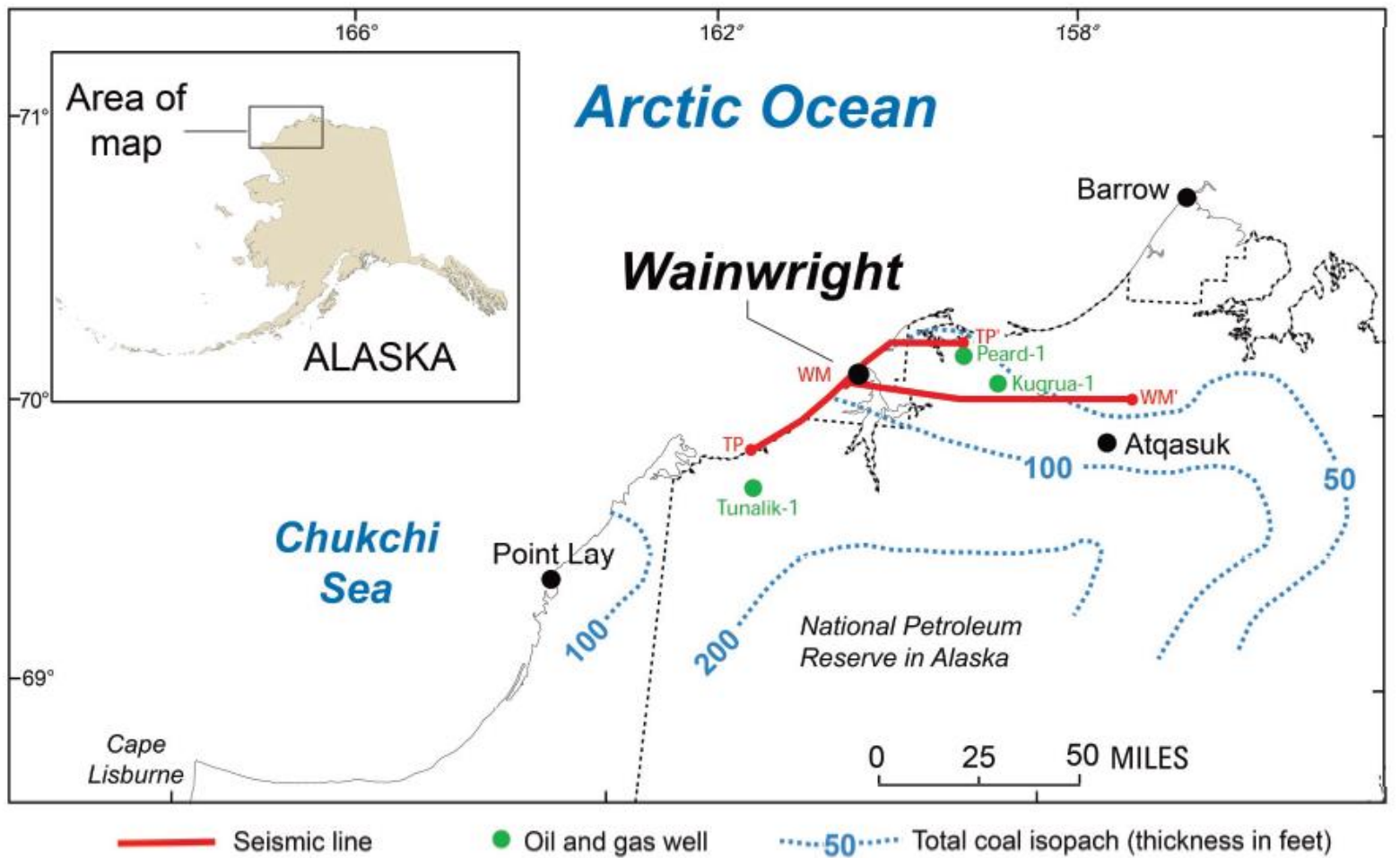

Clark (2014)

Spud Date: June 11, 2007

Completion Date: June 27, 2007

(drilling operations)

Total Depth: 1,613 feet

(continuously-cored from 75-1,605 feet)

Objective: Evaluate coalbed gas potential for local use.

Results: Encountered numerous coal seams, including one 7.5-ftthick seam with significant gas content.

Taken from Clark (2014)

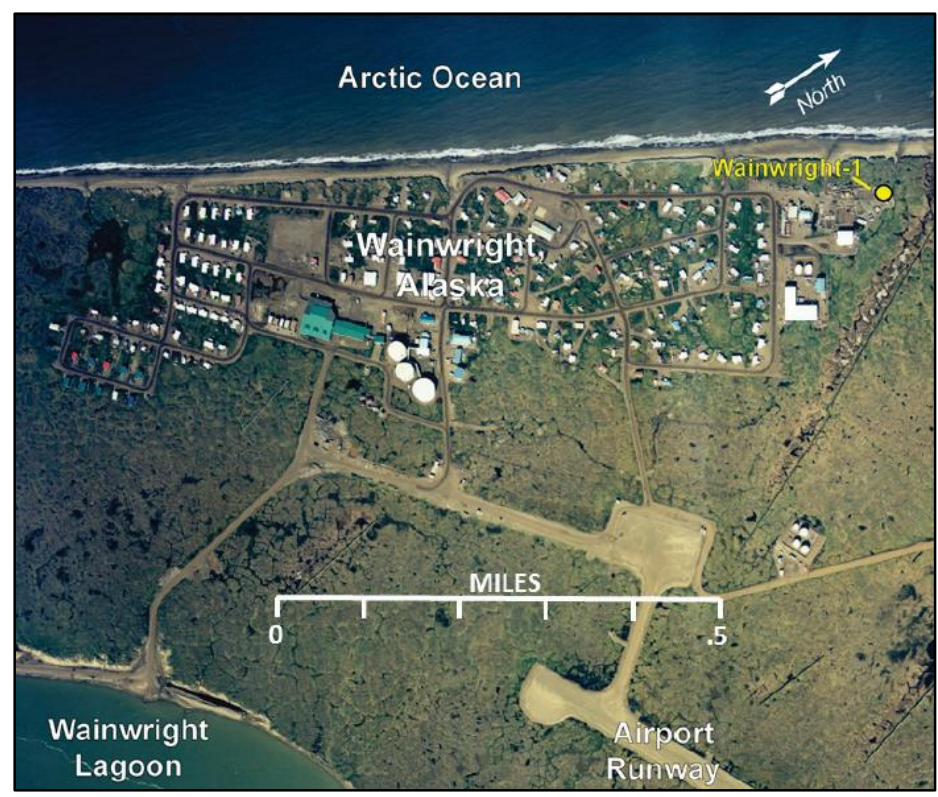

Clark (2014)

API Number: 50301200030000

Seismic location map and 2D seismic line are publicly available U.S. Geological Survey data. Interpretation was done by Paul Decker (Alaska Division of Oil \& Gas) (Decker and LePain, 2016). 


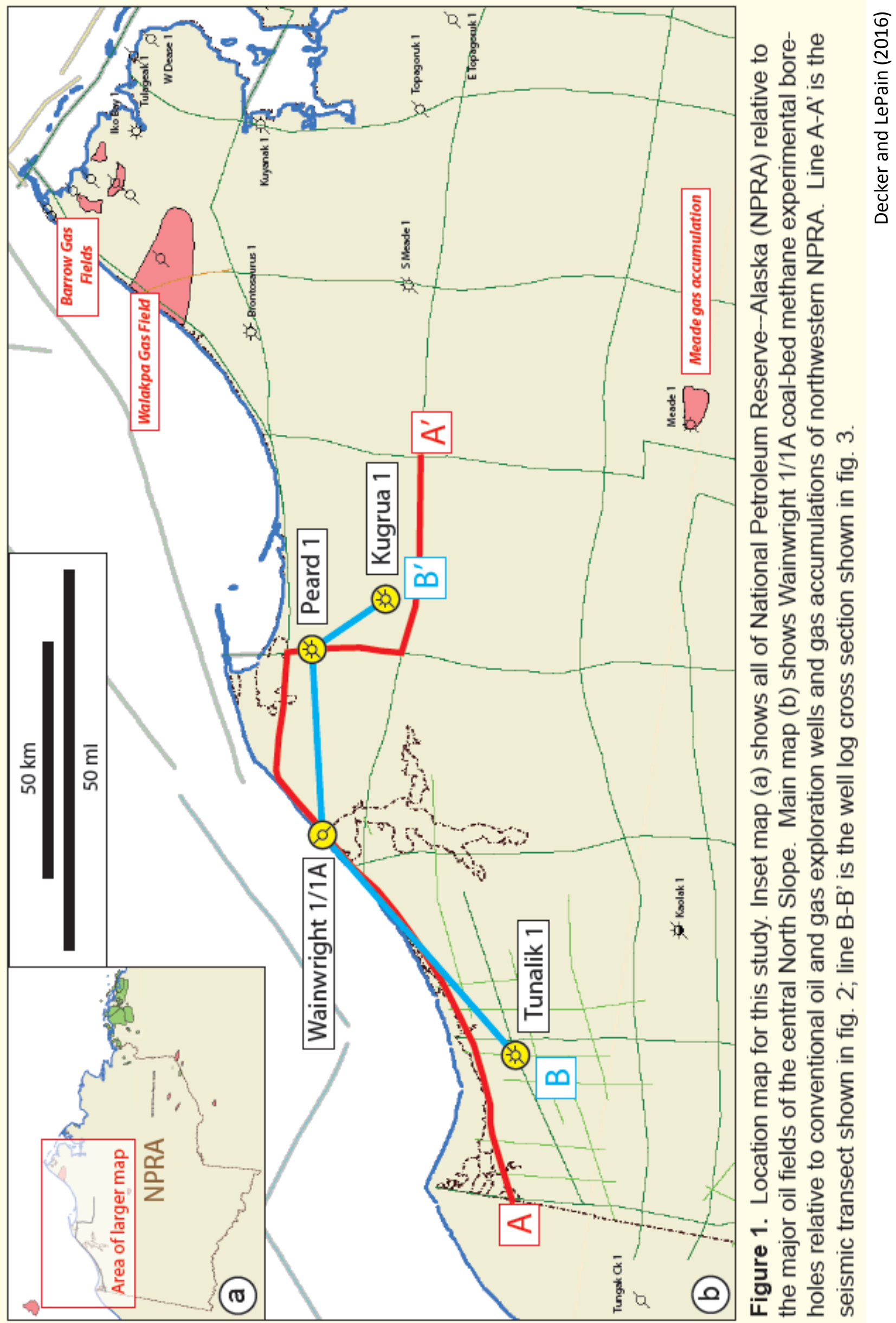




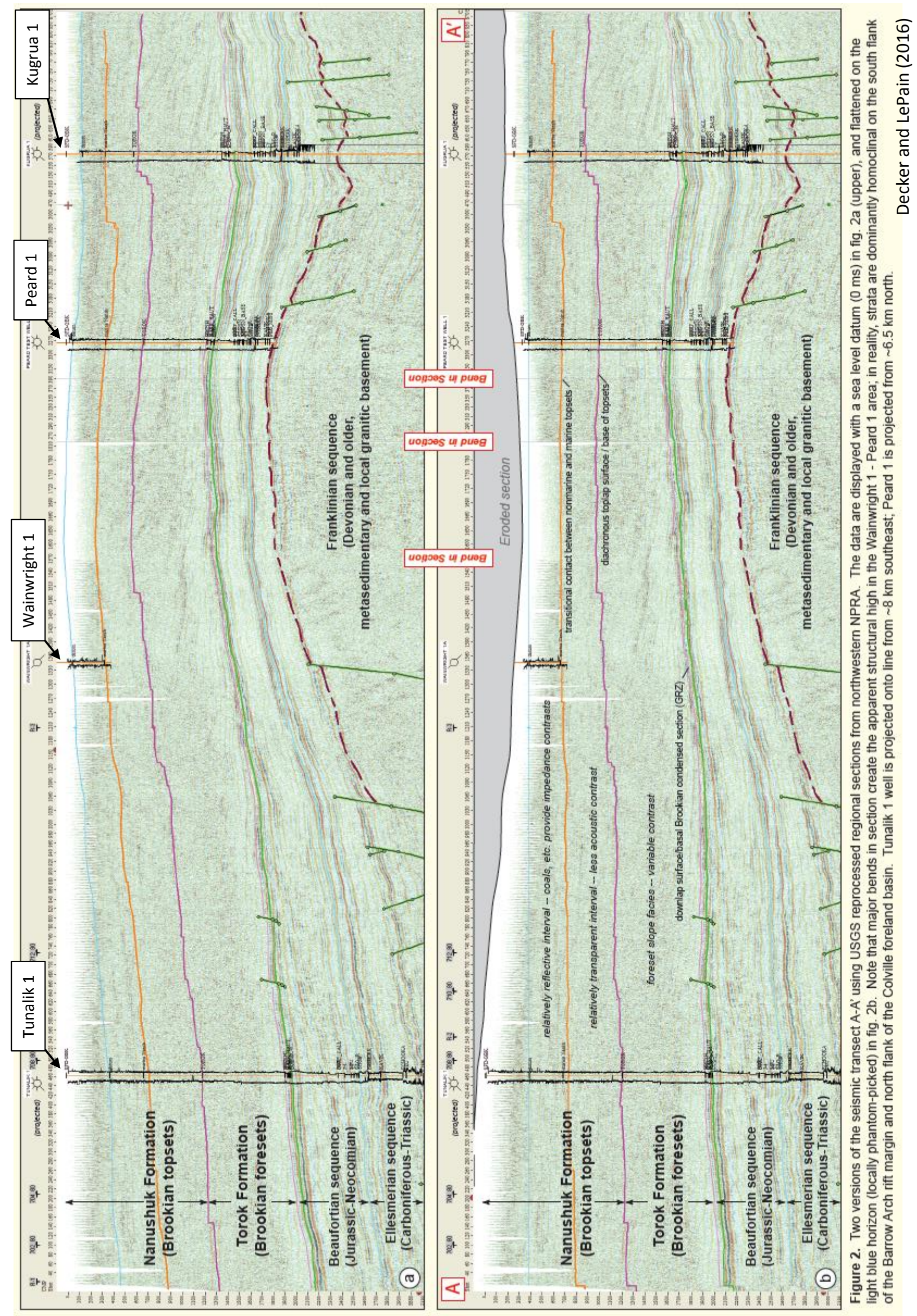




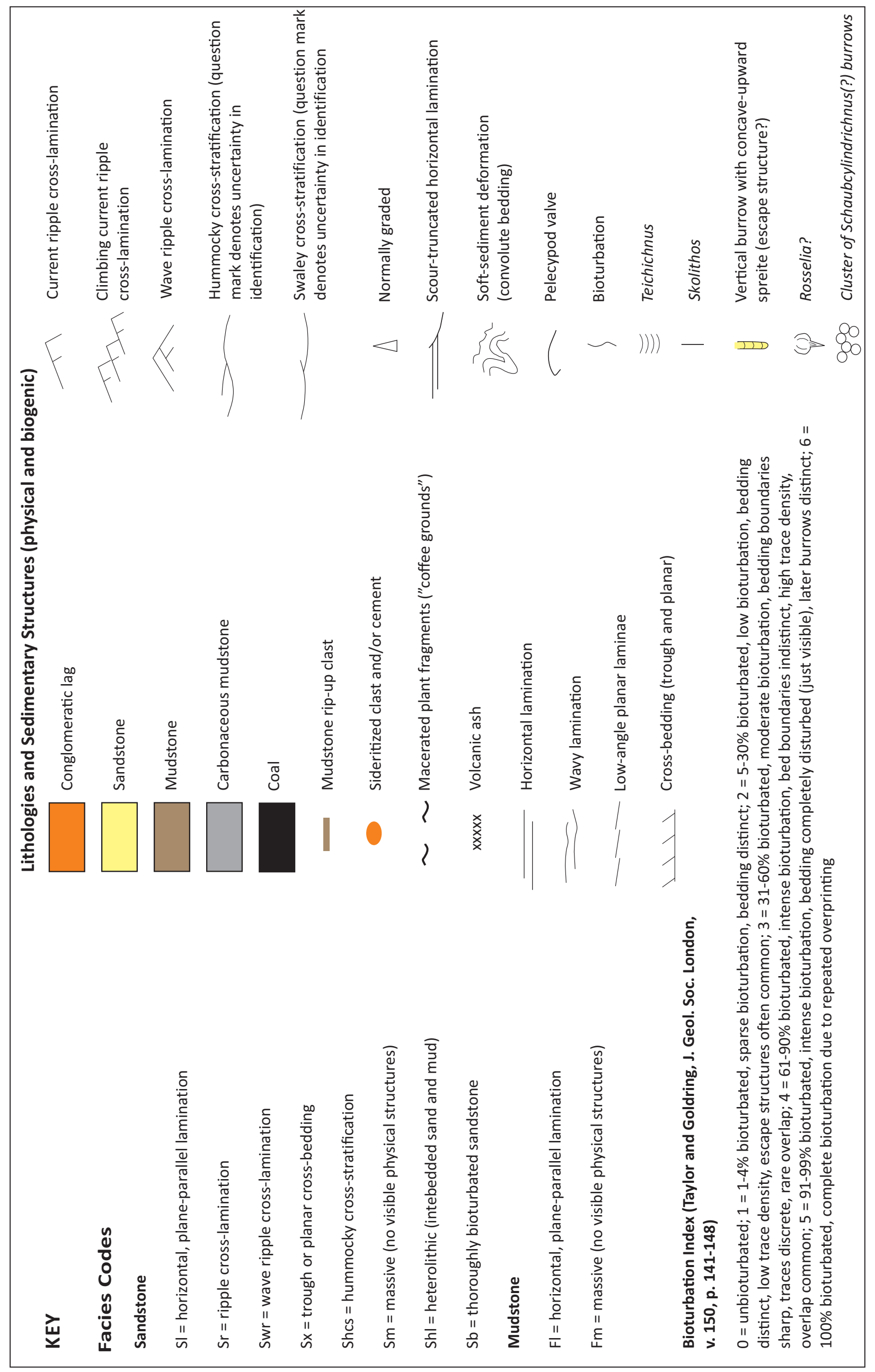



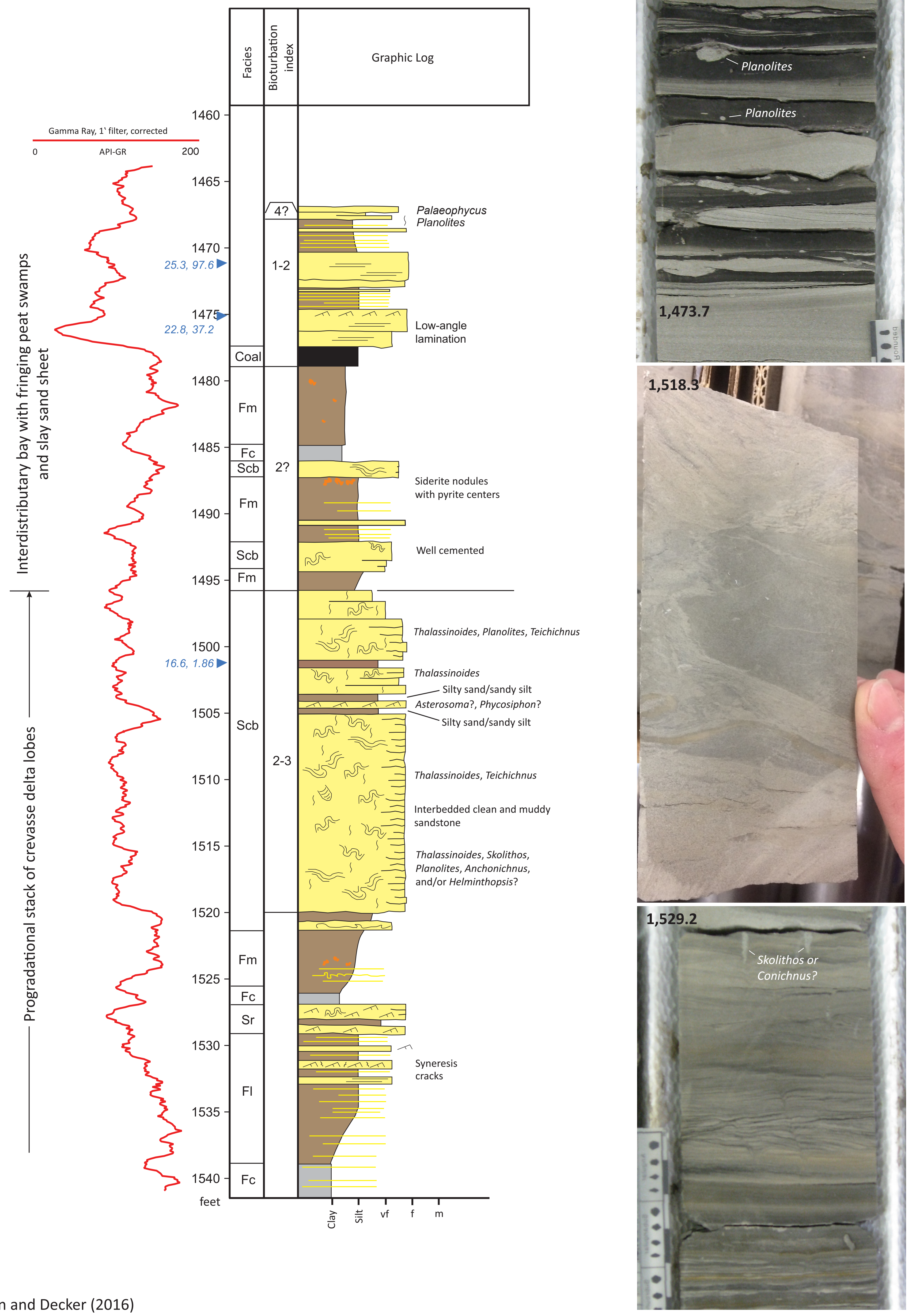


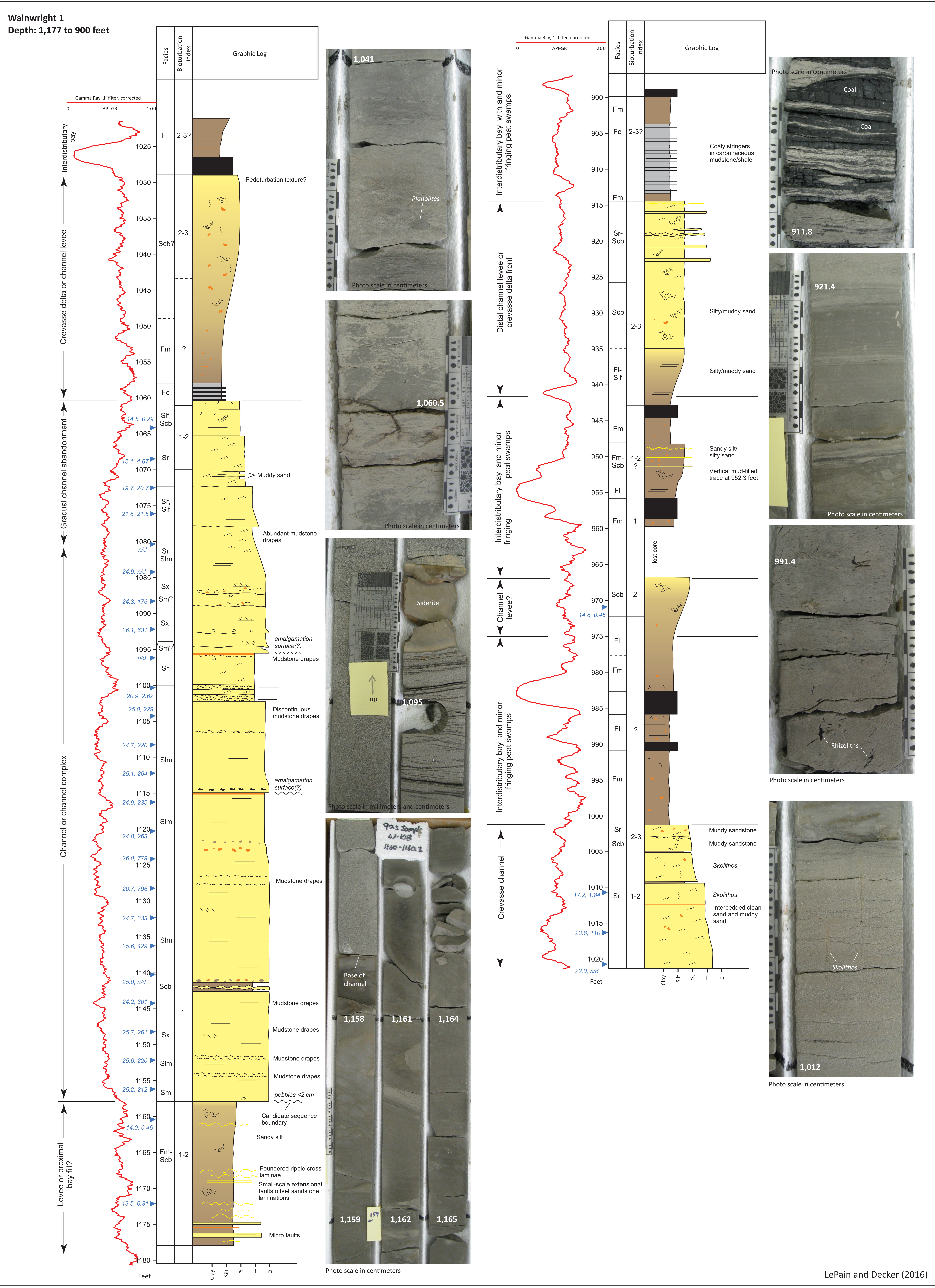




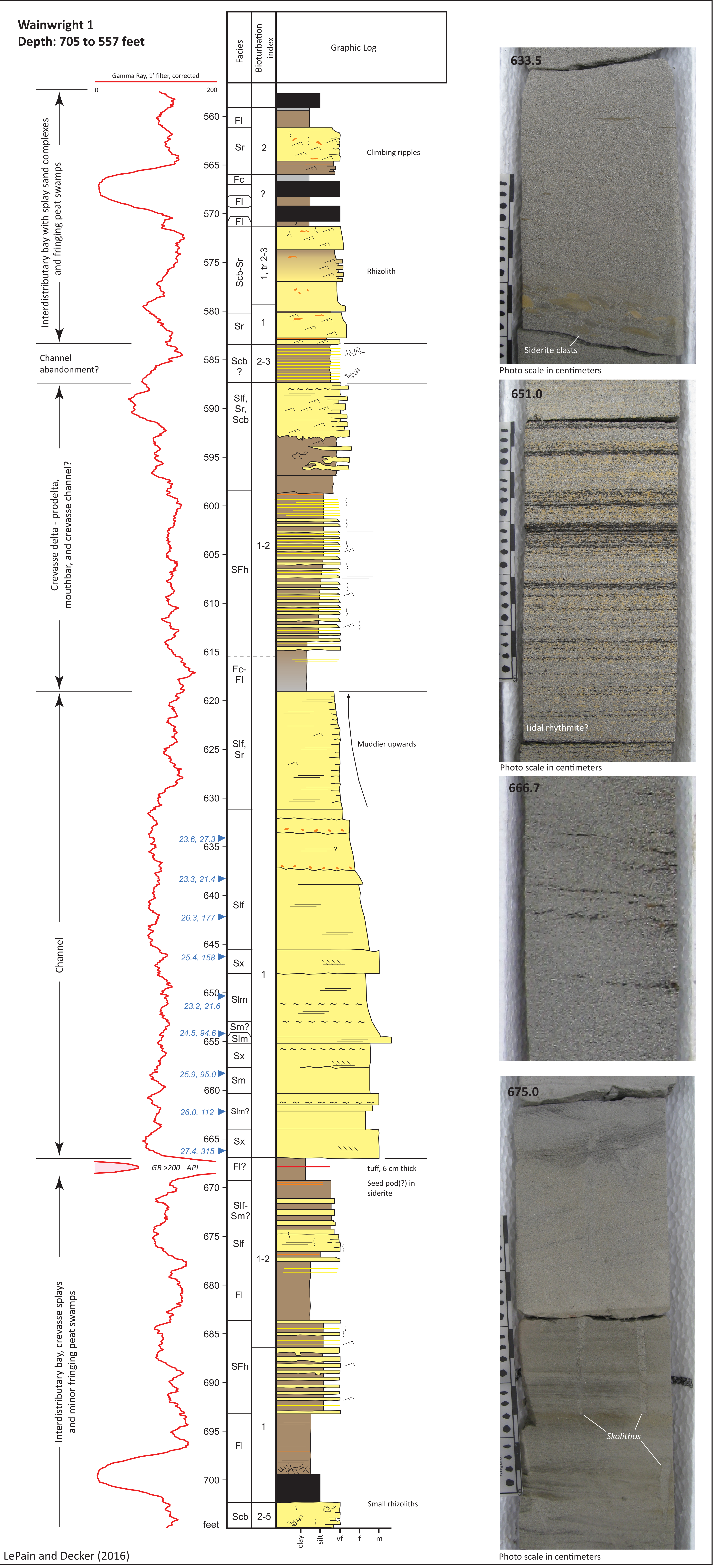



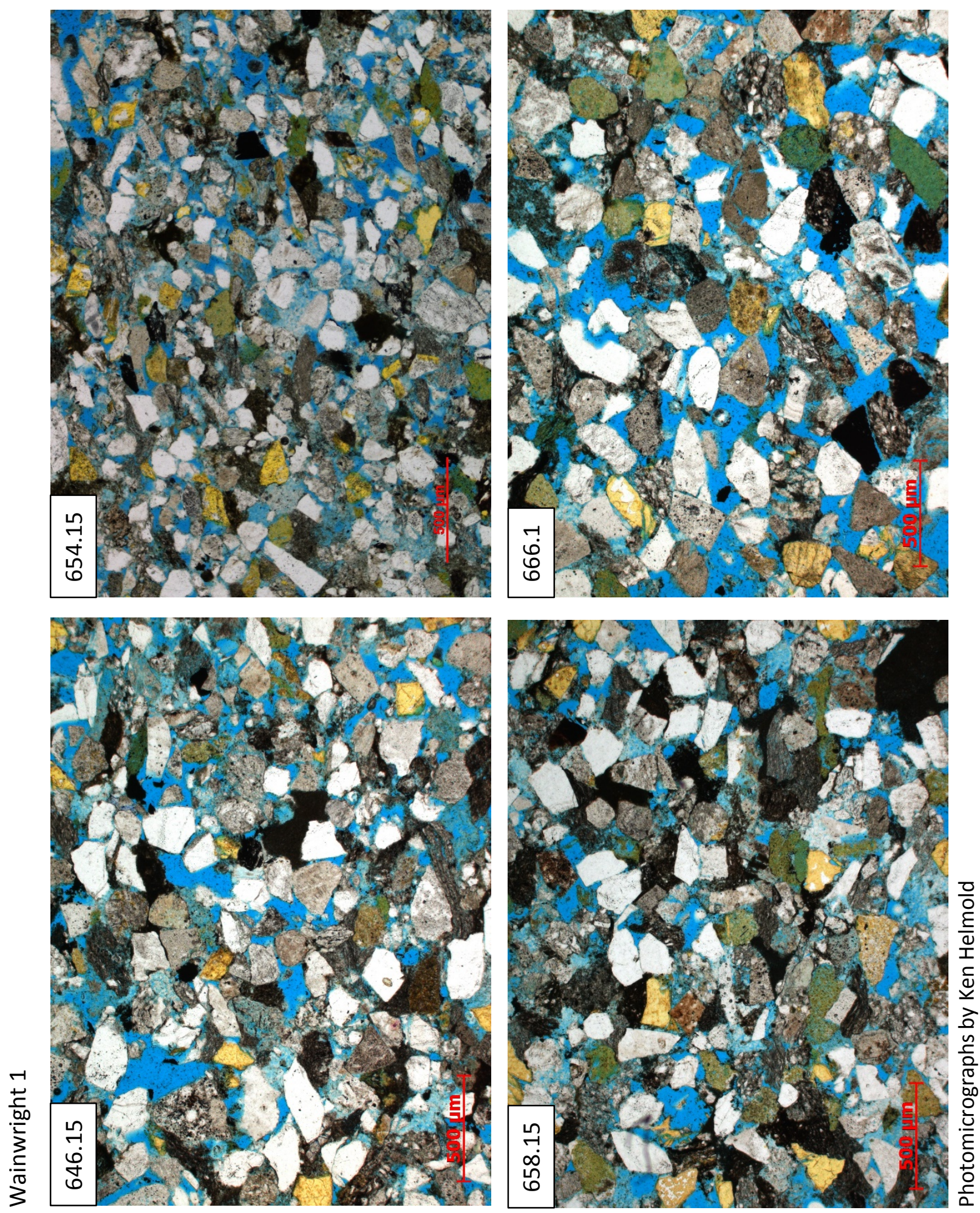

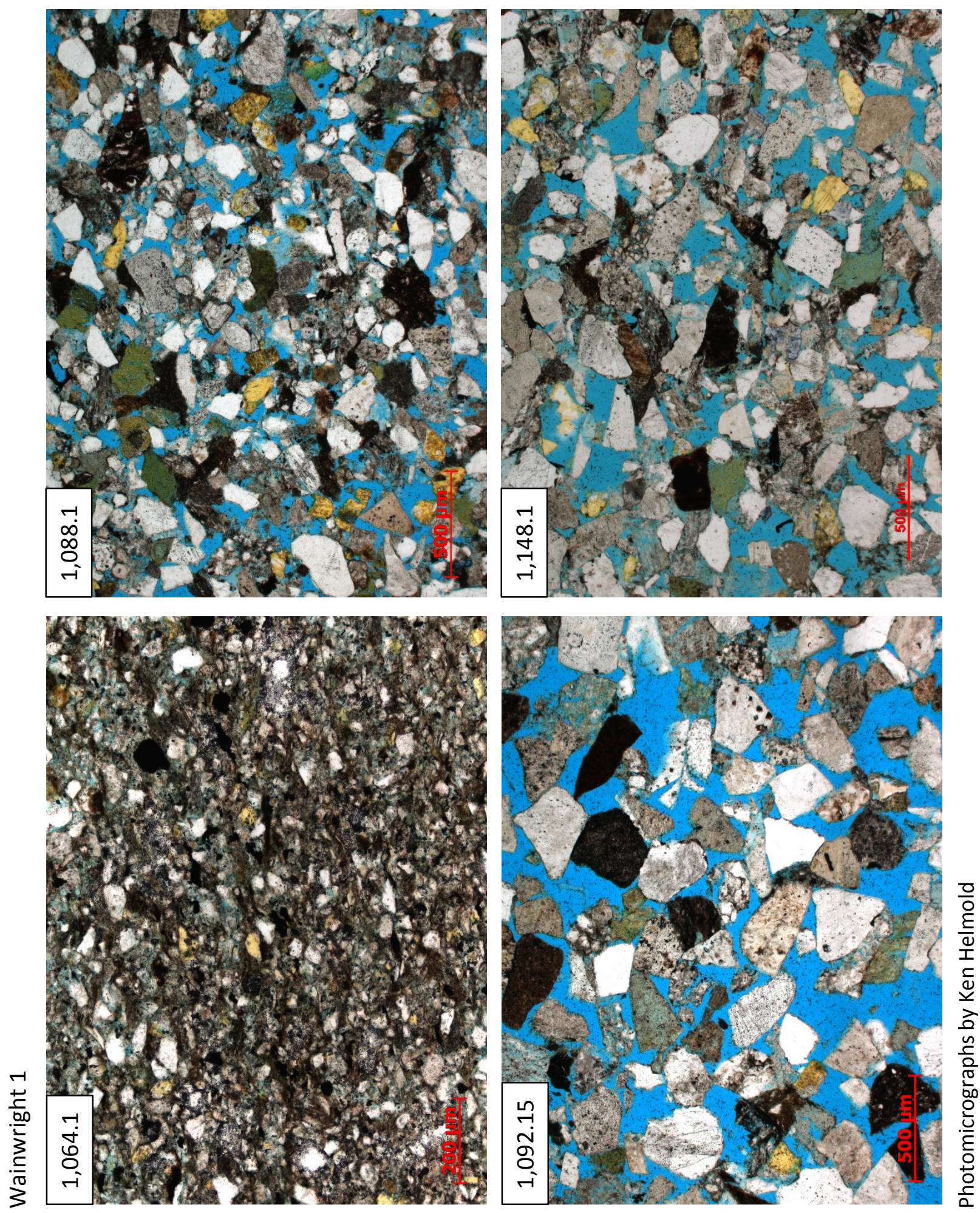


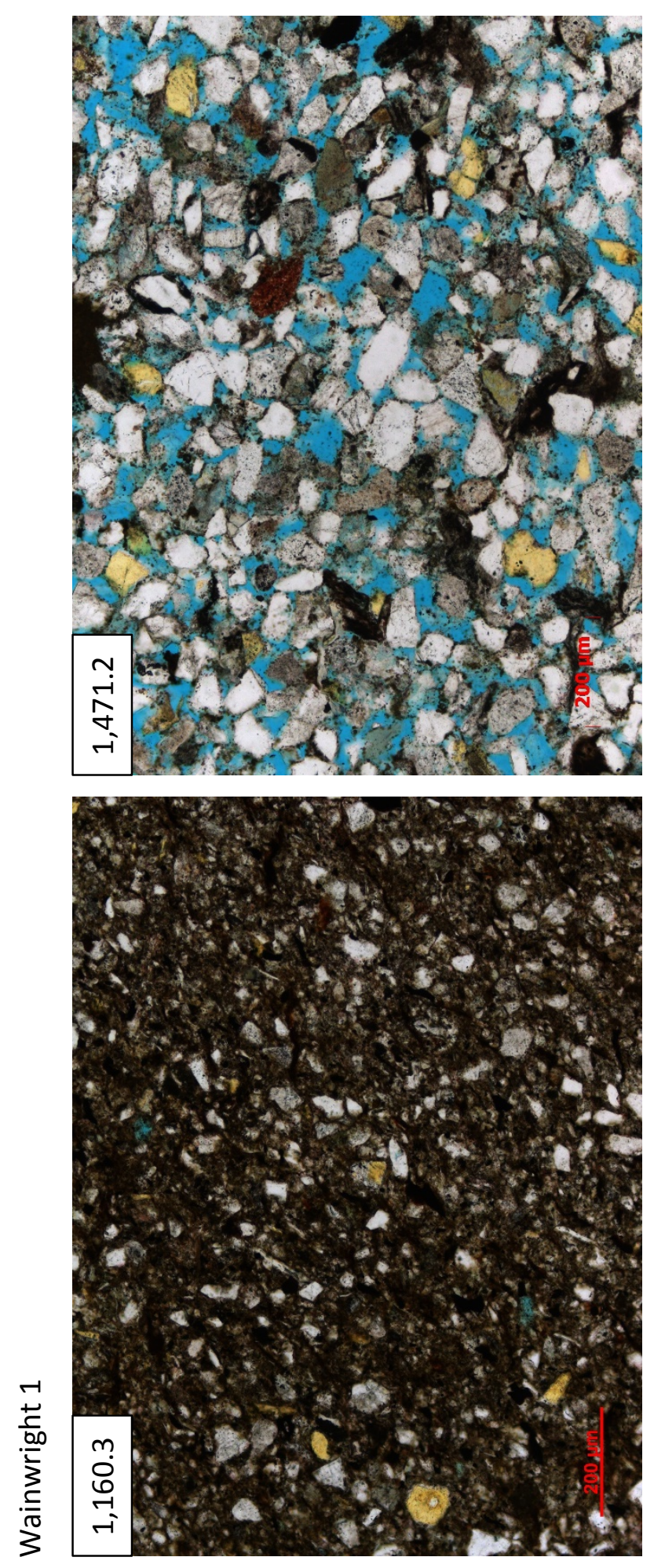

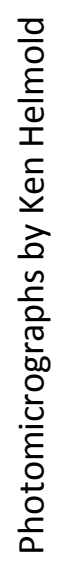

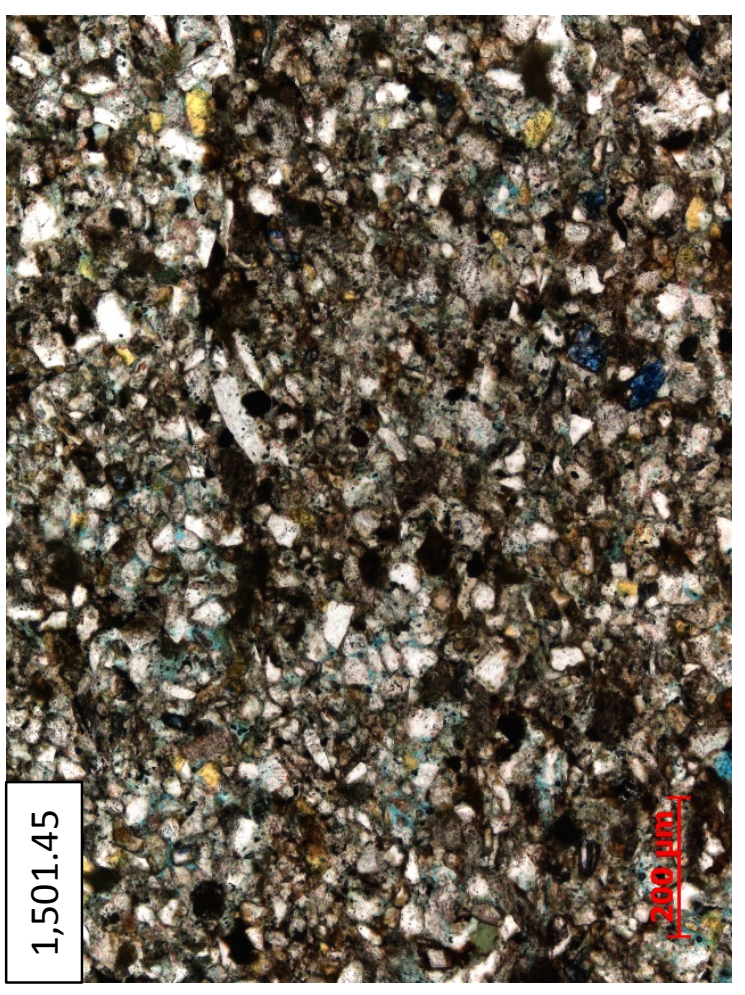




\section{Wolf Creek Test Well 3}

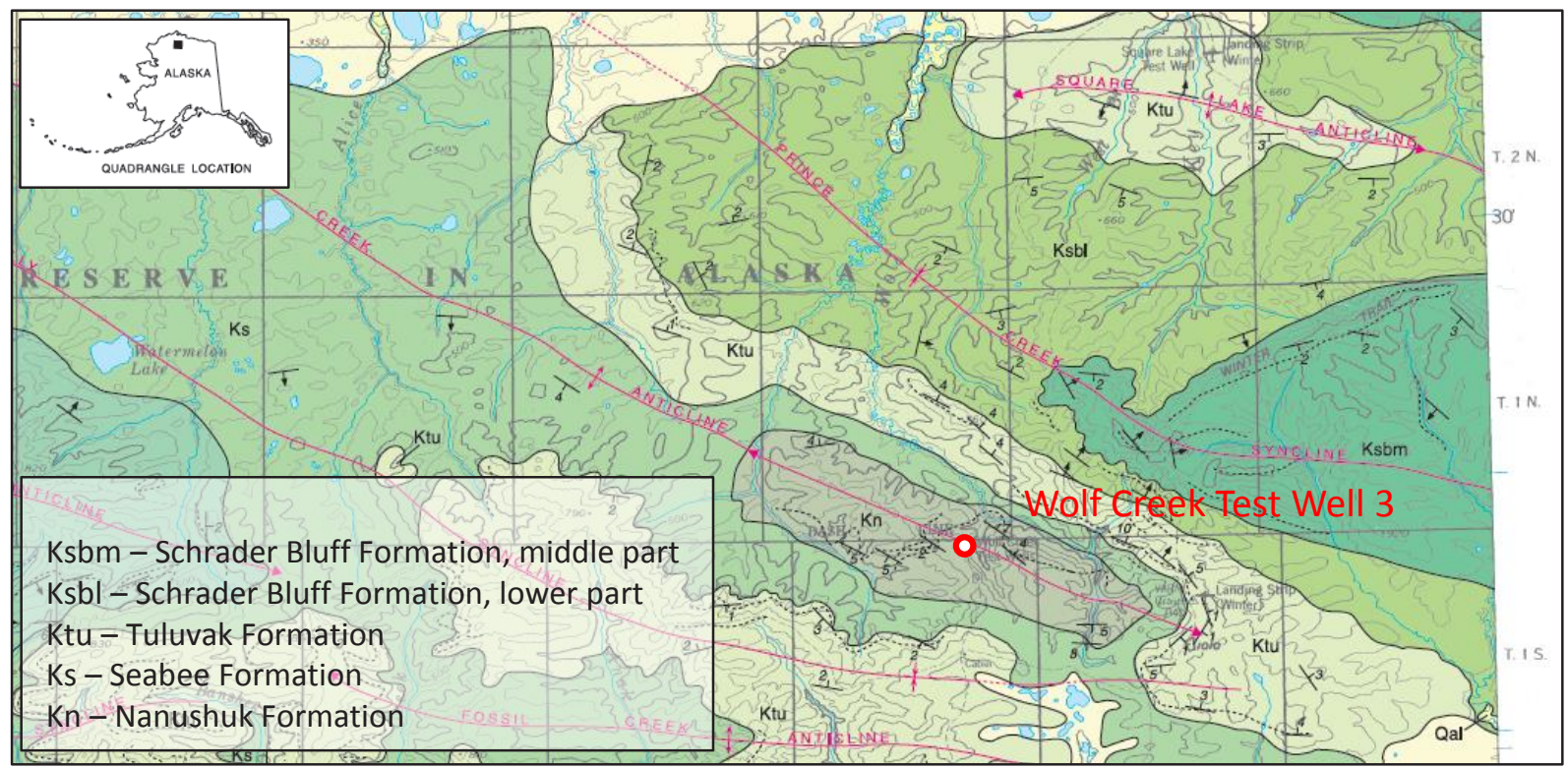

Townships provide scale ( 6 miles on a side). North is top of map.

After Mull and others (2005)

Spud Date: August 20, 1952

Completion Date: November 3, 1952

Total Depth: 3,760 feet

Objective: Lower, dominantly marine part of the Nanushuk Formation (Grandstand Formation of former usage) near crest of anticline.

Results: A few shows of gas in five formation tests.

Taken from Collins (1959).

API Number: 50119100100000

Seismic location map and 2D seismic line are publicly available U.S. Geological Survey data. Interpretation was done by Holly Fair (Alaska Division of Oil \& Gas). 


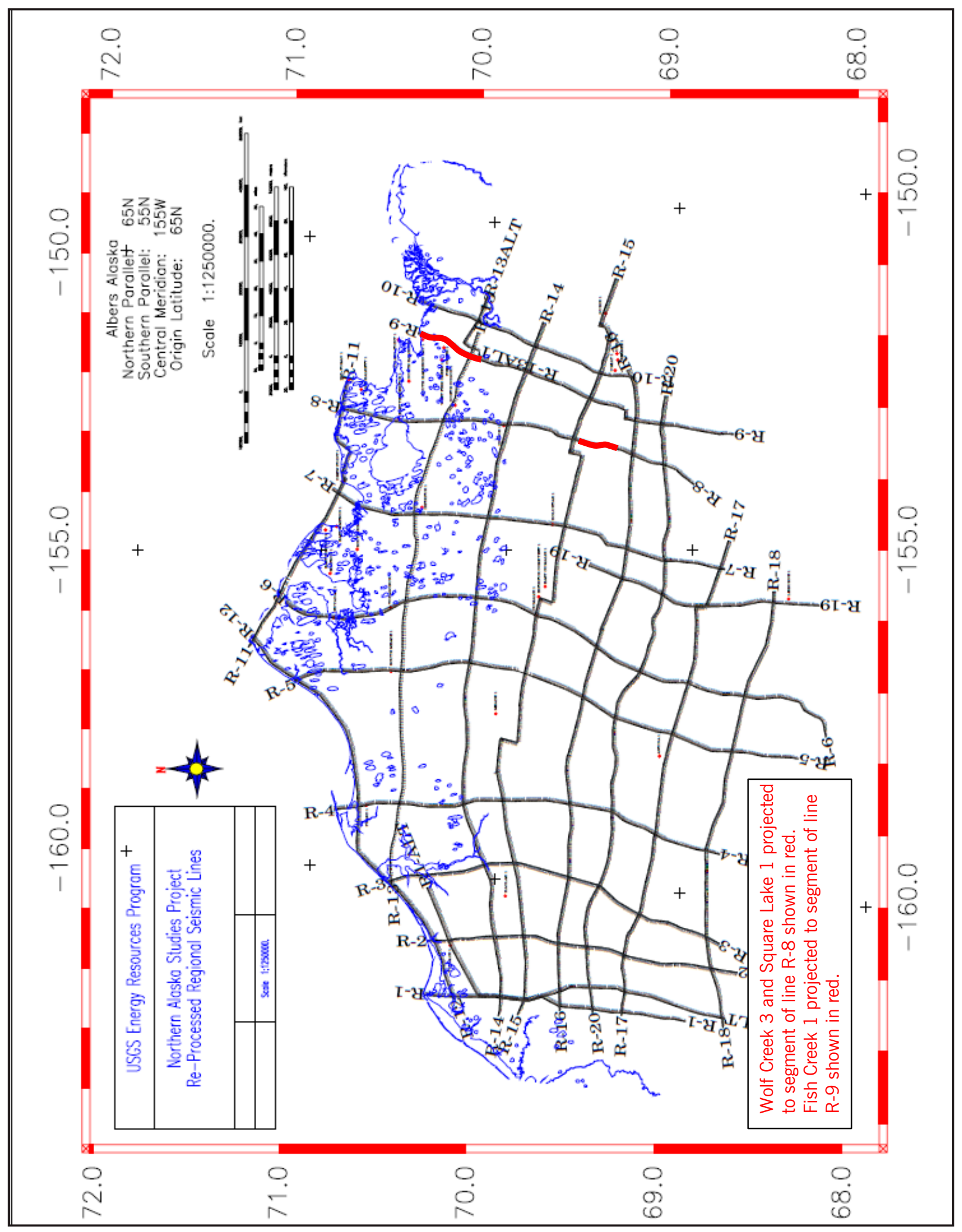




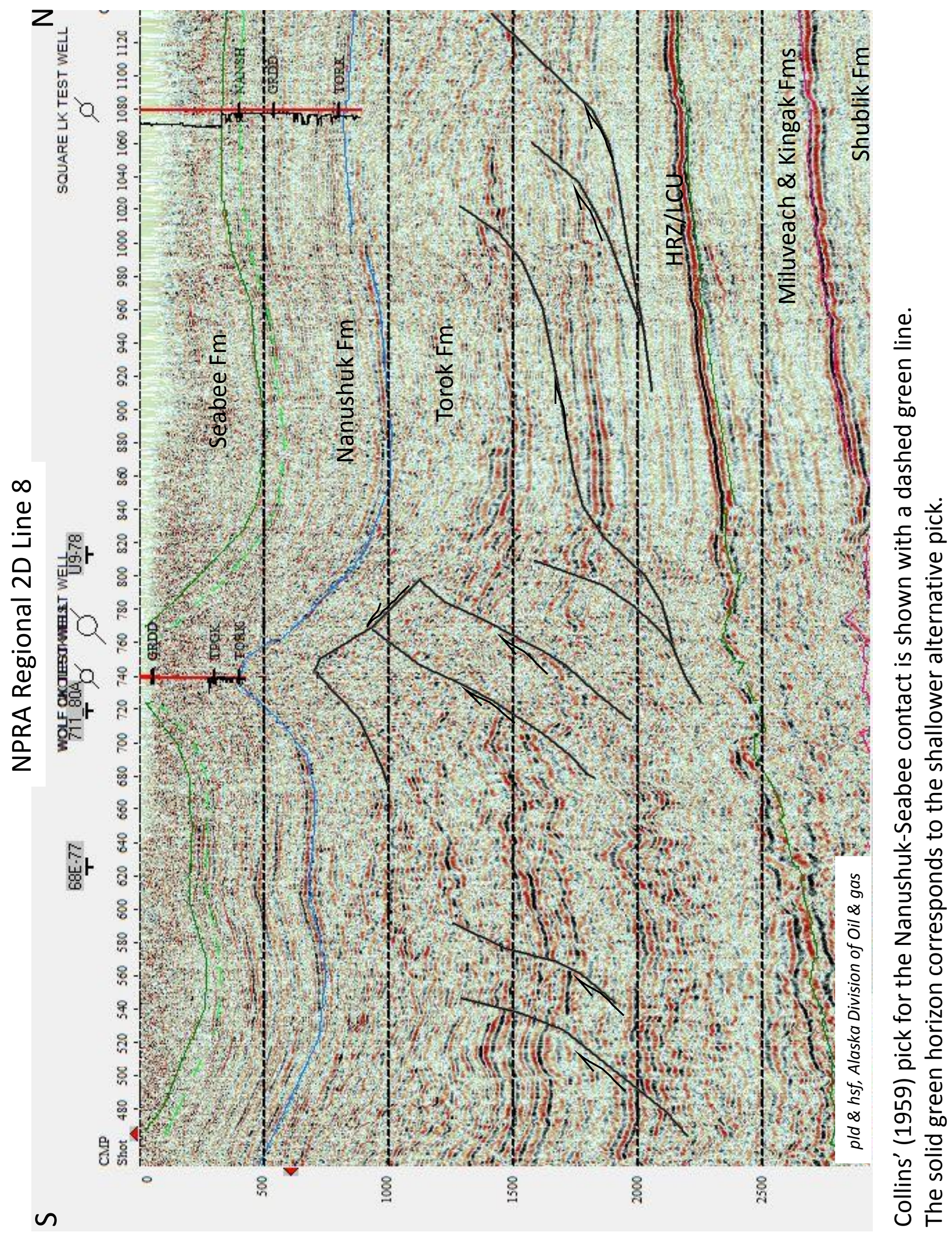


Wolf Creek 3 Nanushuk Group

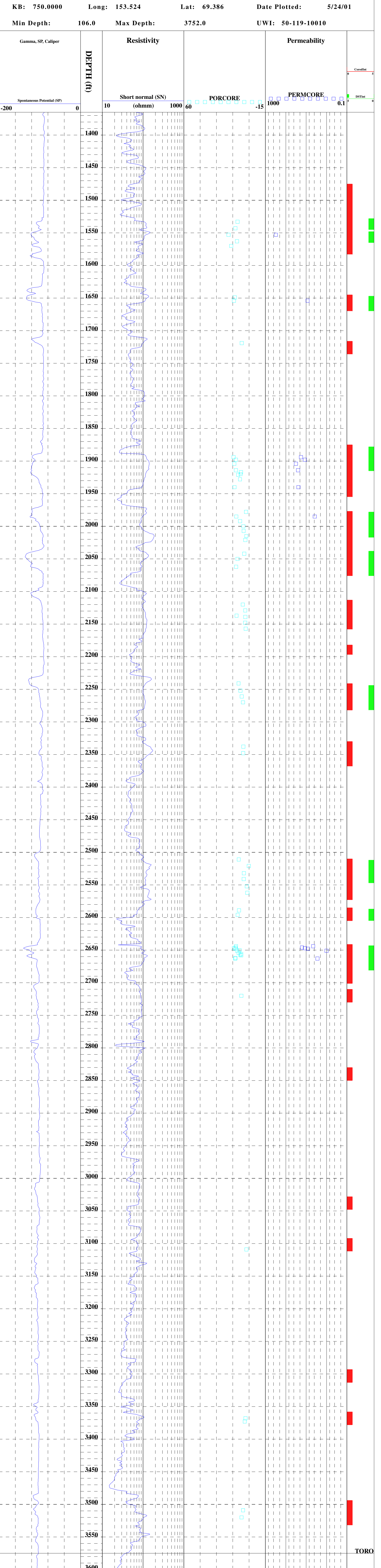

From Nelson and Kibler (2001) 


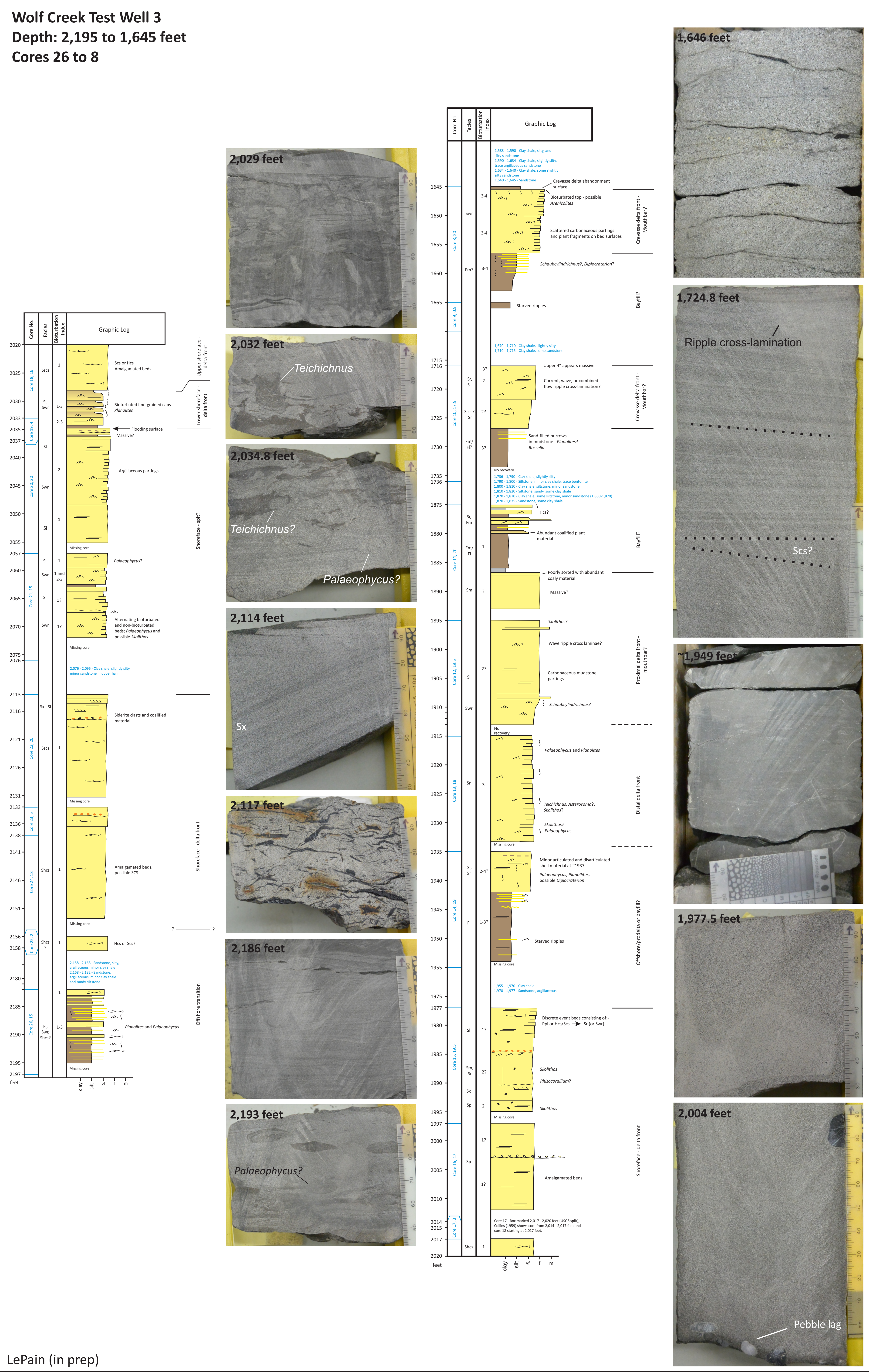



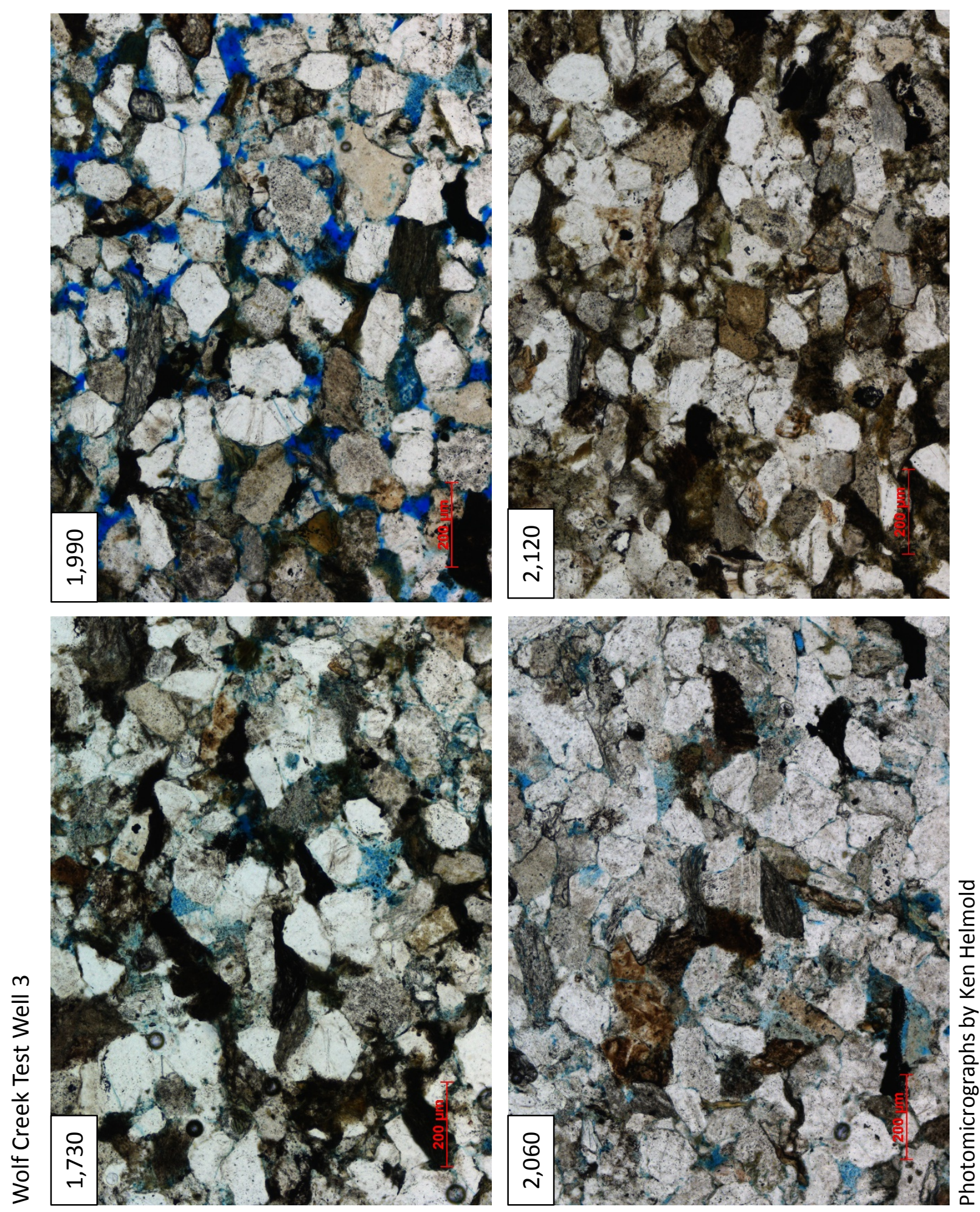


\section{Square Lake Test Well 1}

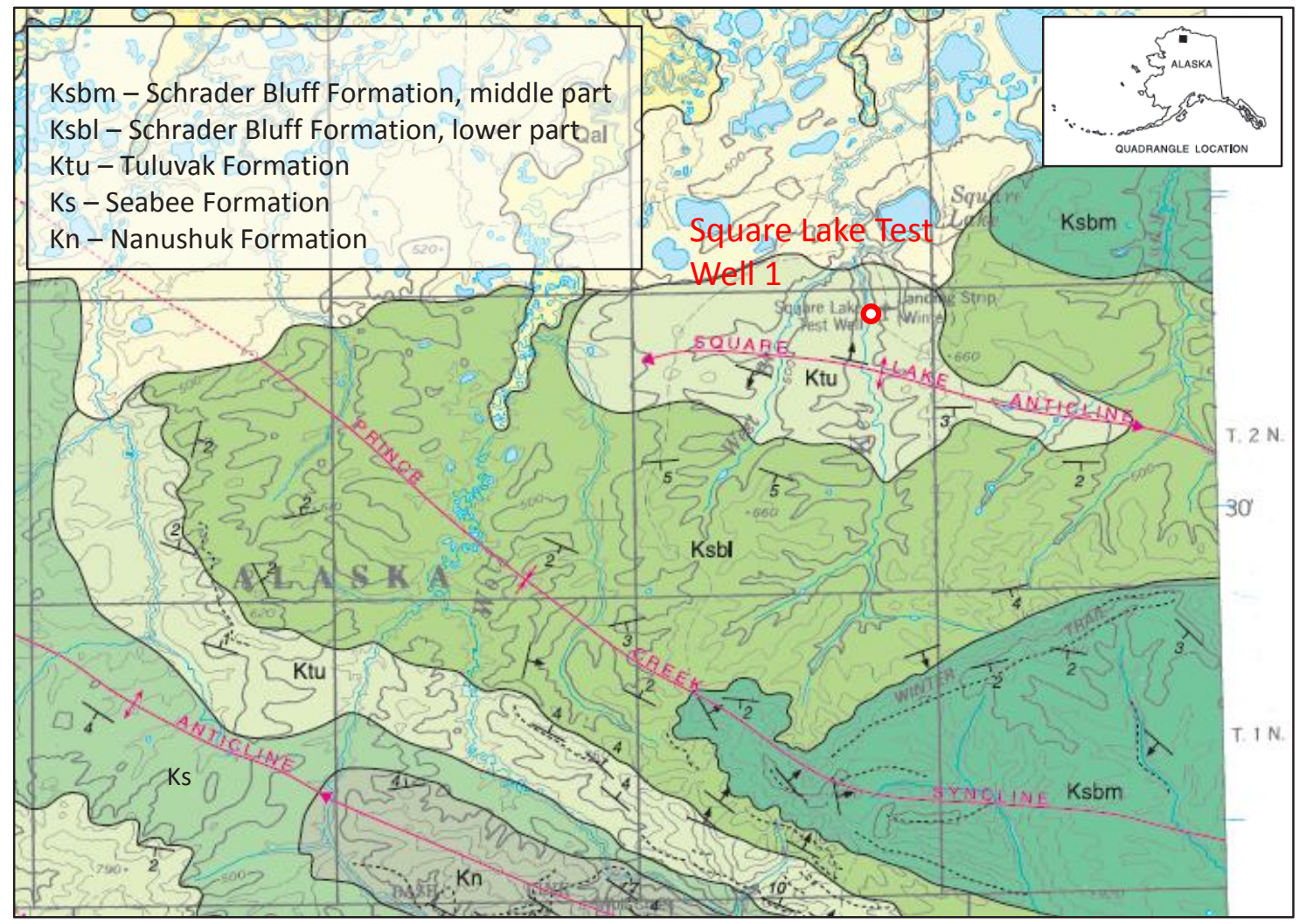

Townships provide scale ( 6 miles on a side). North is top of map.

After Mull and others (2005)

Spud Date: January 26, 1952

Completion Date: April 18, 1952

Total Depth: 3,987 feet

Objective: Cretaceous strata in anticline defined on seismic data.

Results: "No commercial shows of oil were found in Square Lake Test Well 1, but some gas was produced from sandstone beds between 1,600 and 1,900 feet." Twelve formation tests were conducted and two "resulted in moderate to strong blows of gas."

Taken from Collins (1959)

API Number: 50119100070000

Seismic location map and 2D seismic line are publicly available U.S. Geological Survey data. Interpretation was done by Holly Fair (Alaska Division of Oil \& Gas). 


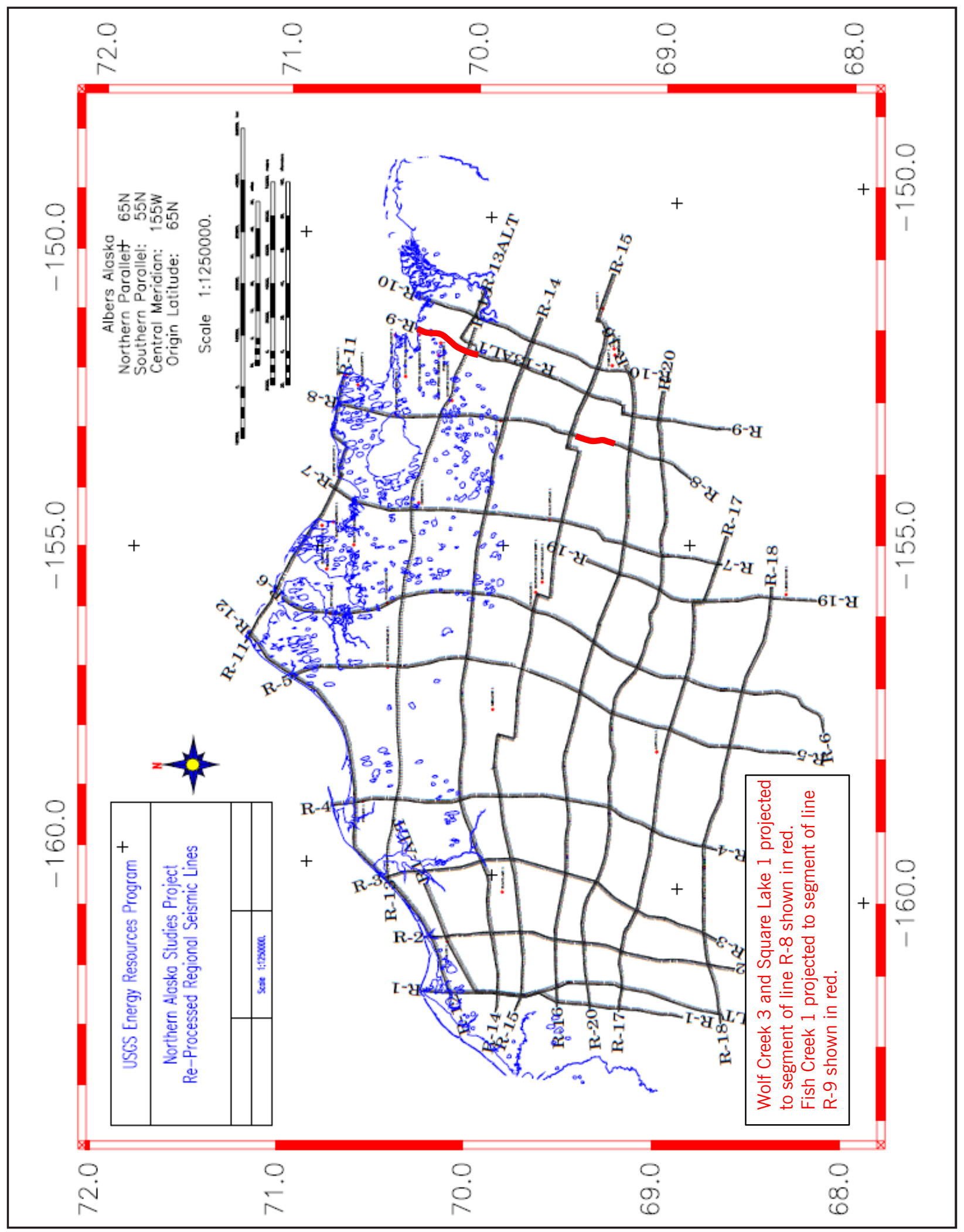




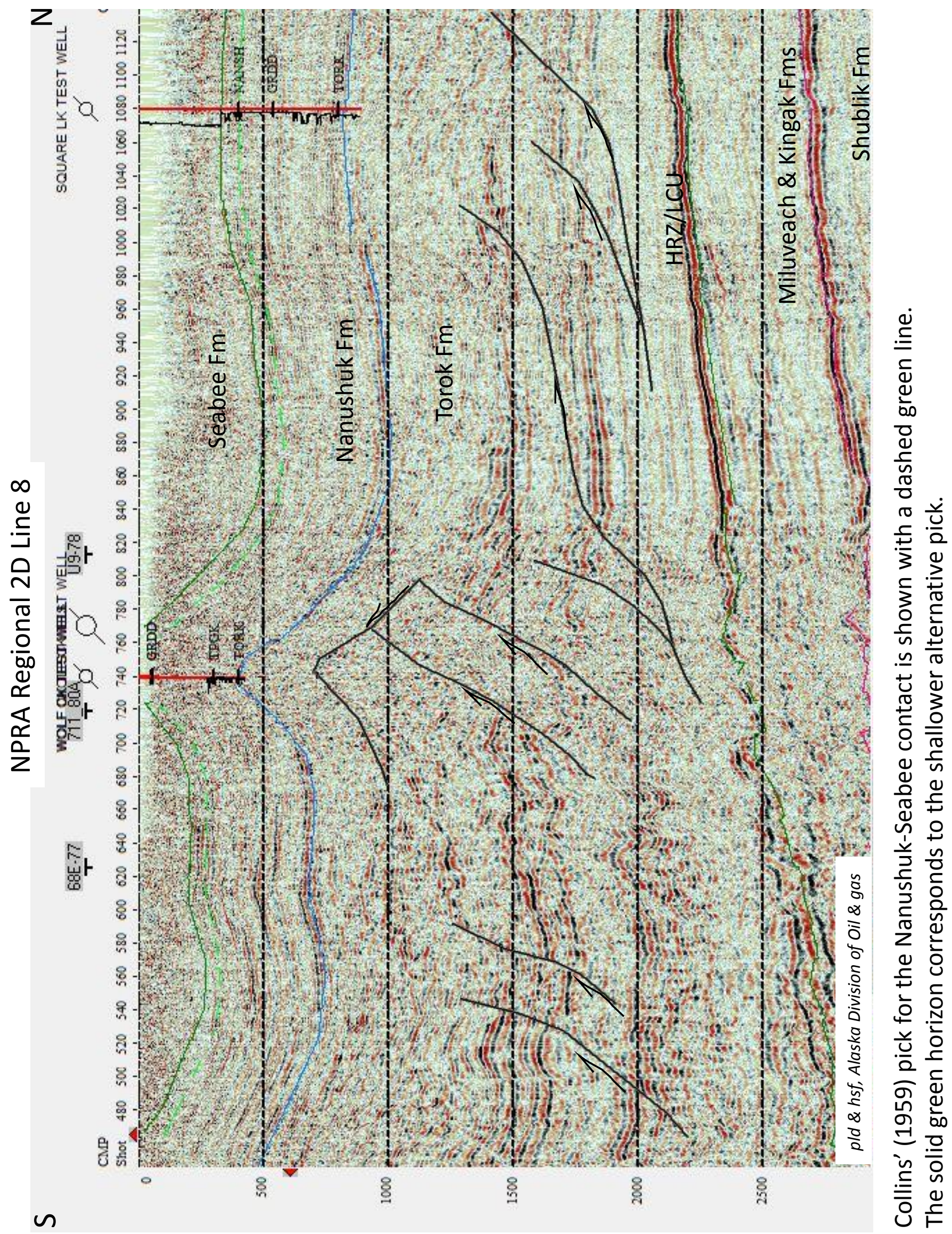




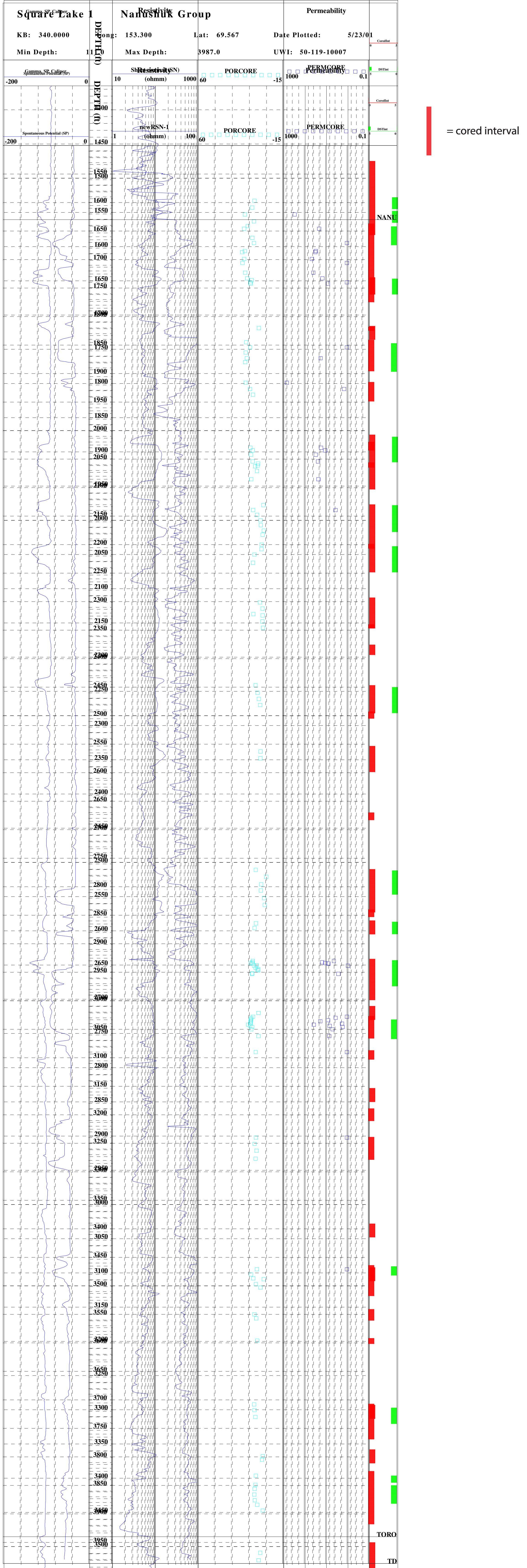

From Nelson and Kibler (2001) 


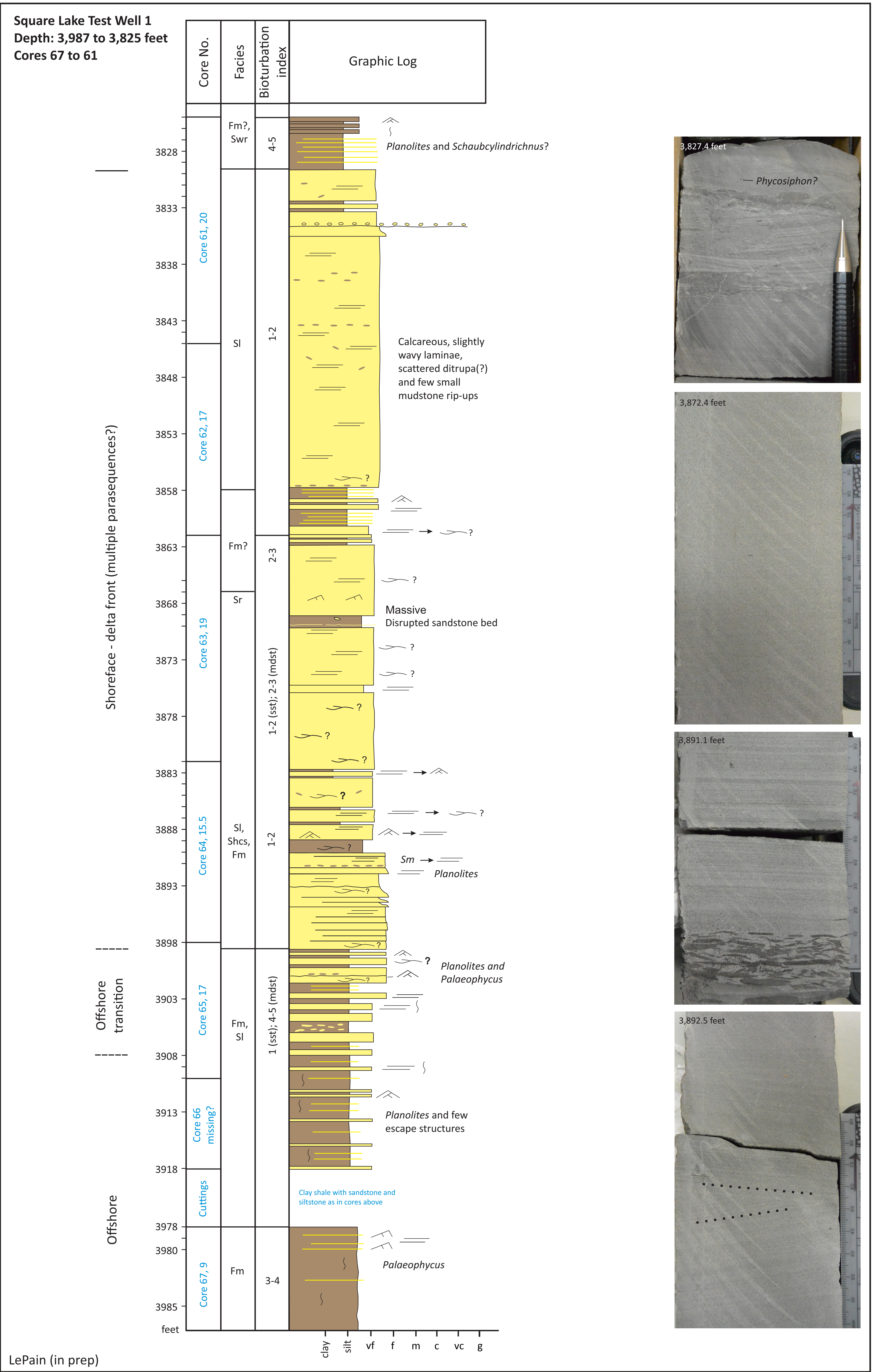



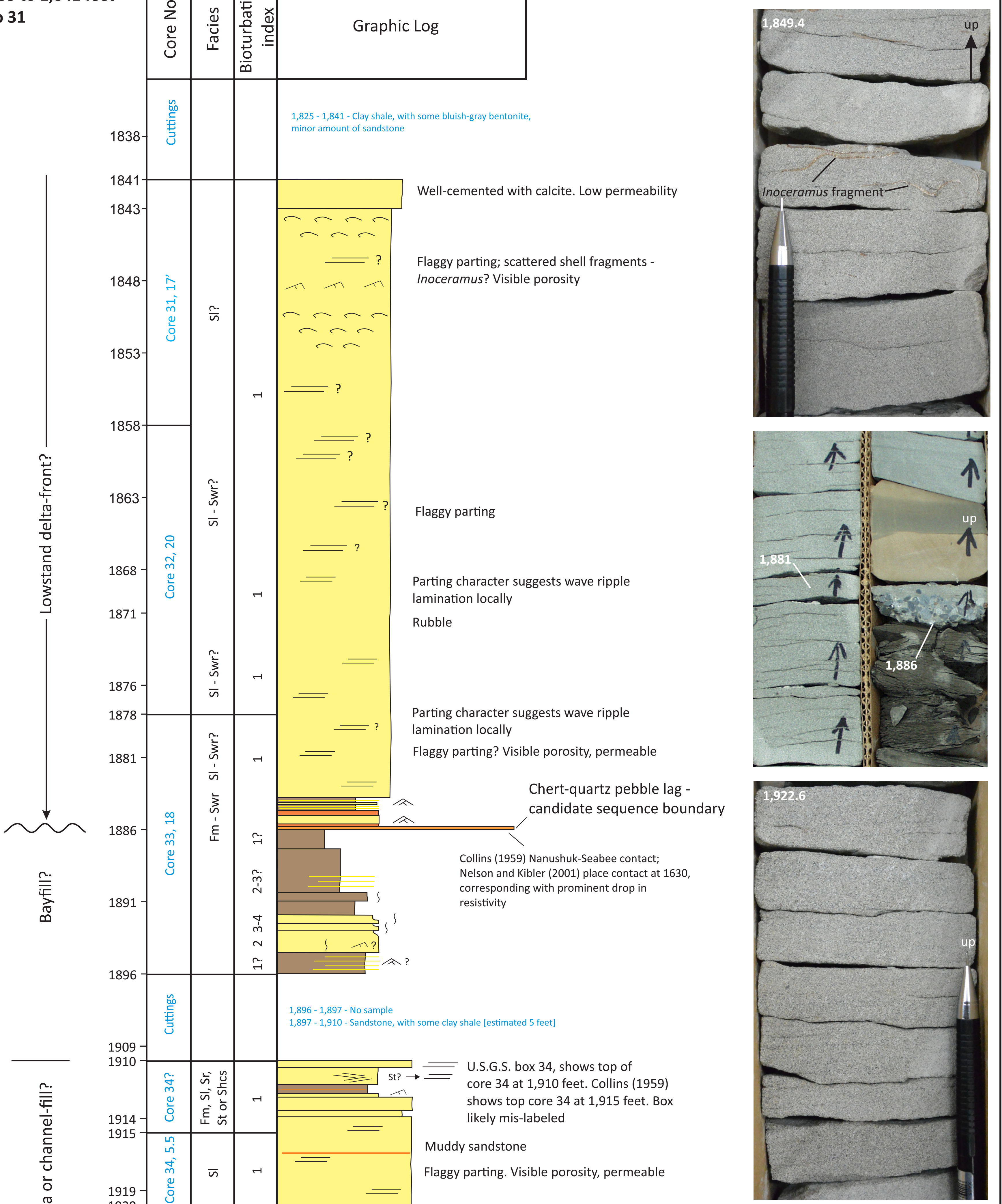

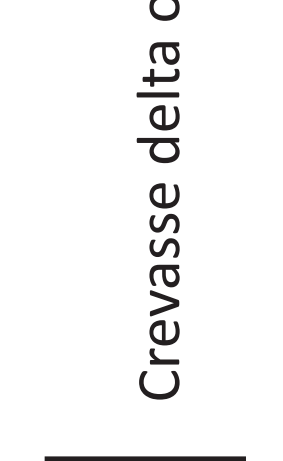

\section{Flaggy parting. Visible porosity, permeable}
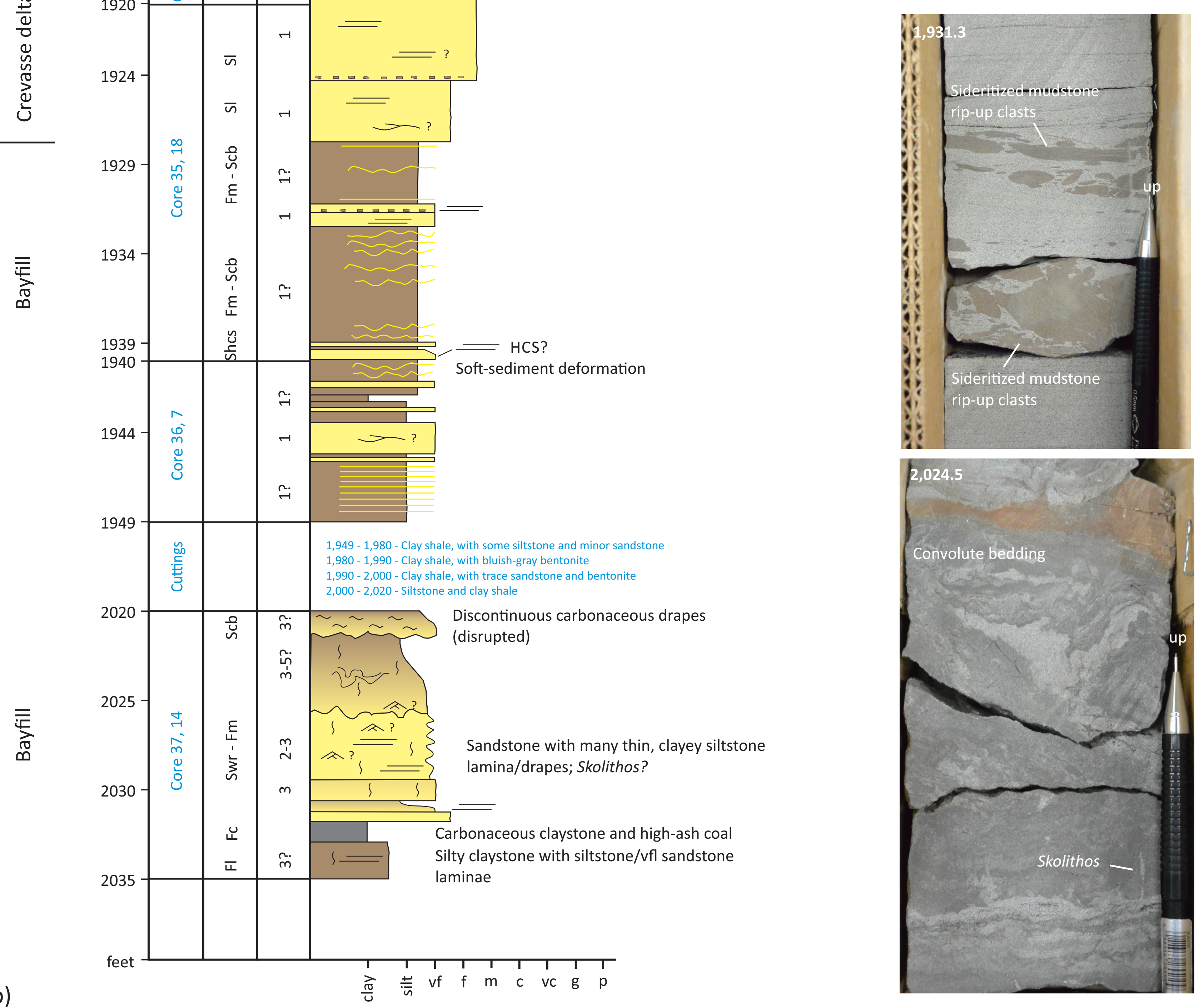


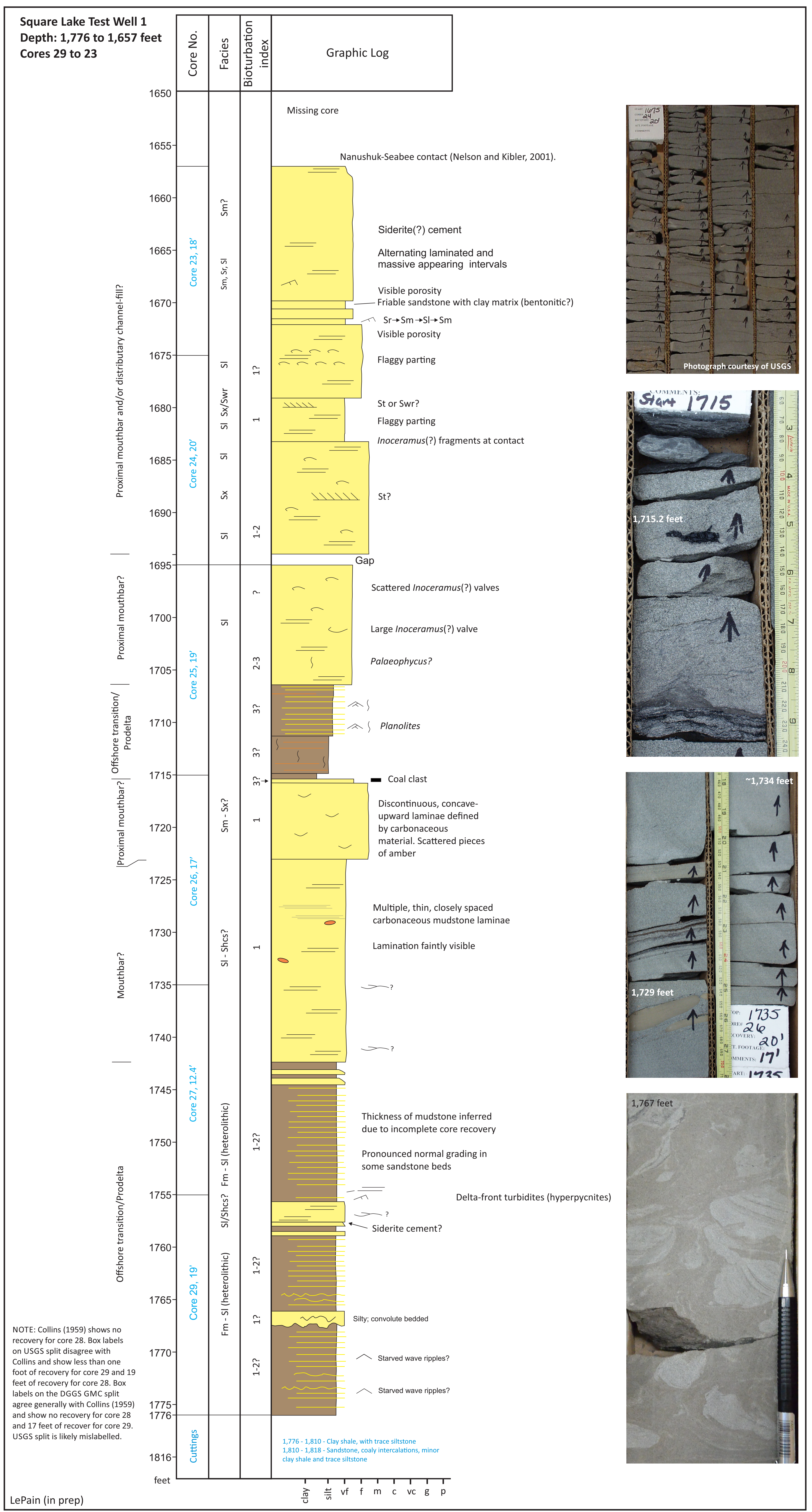



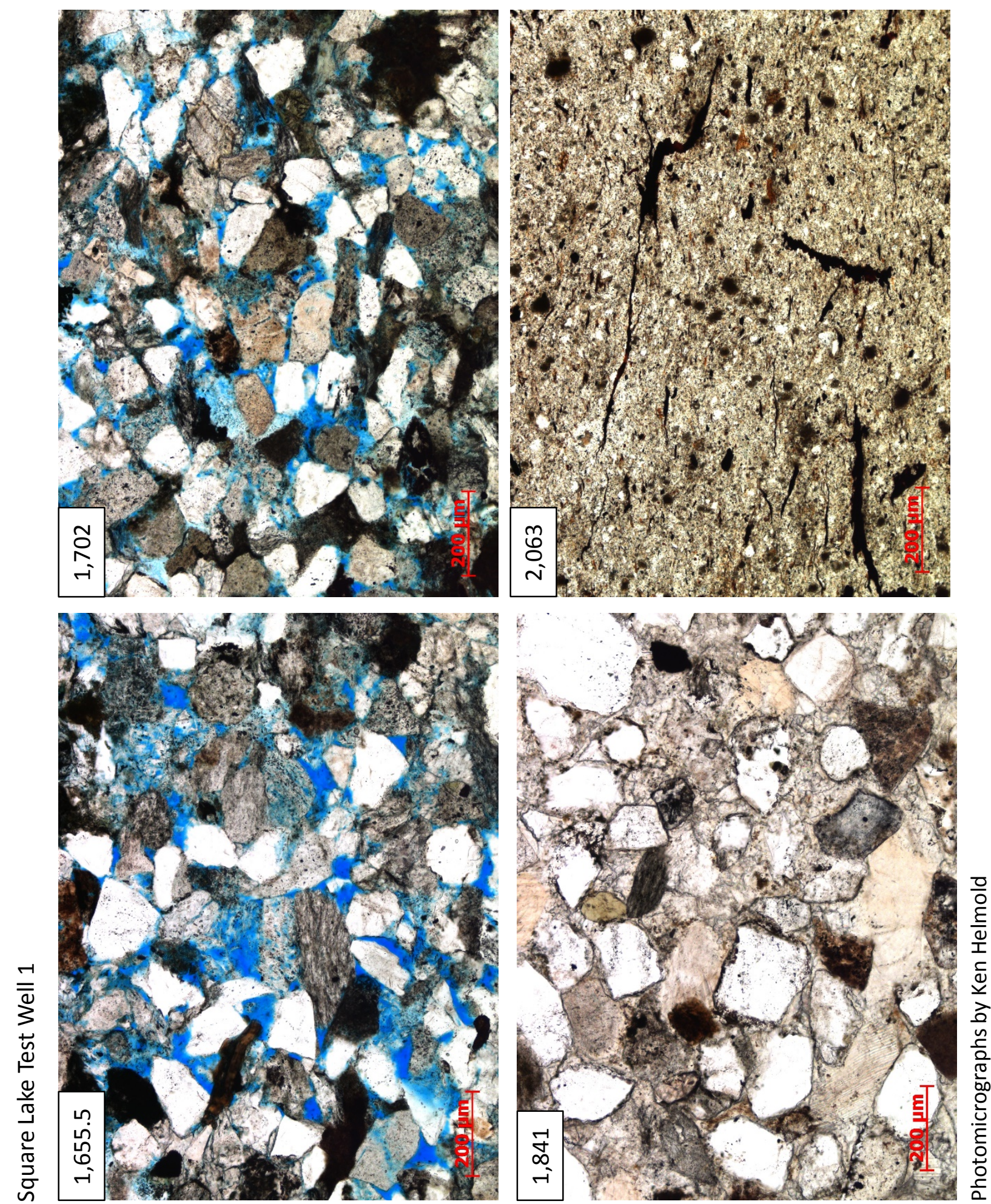


\section{Umiat 18}

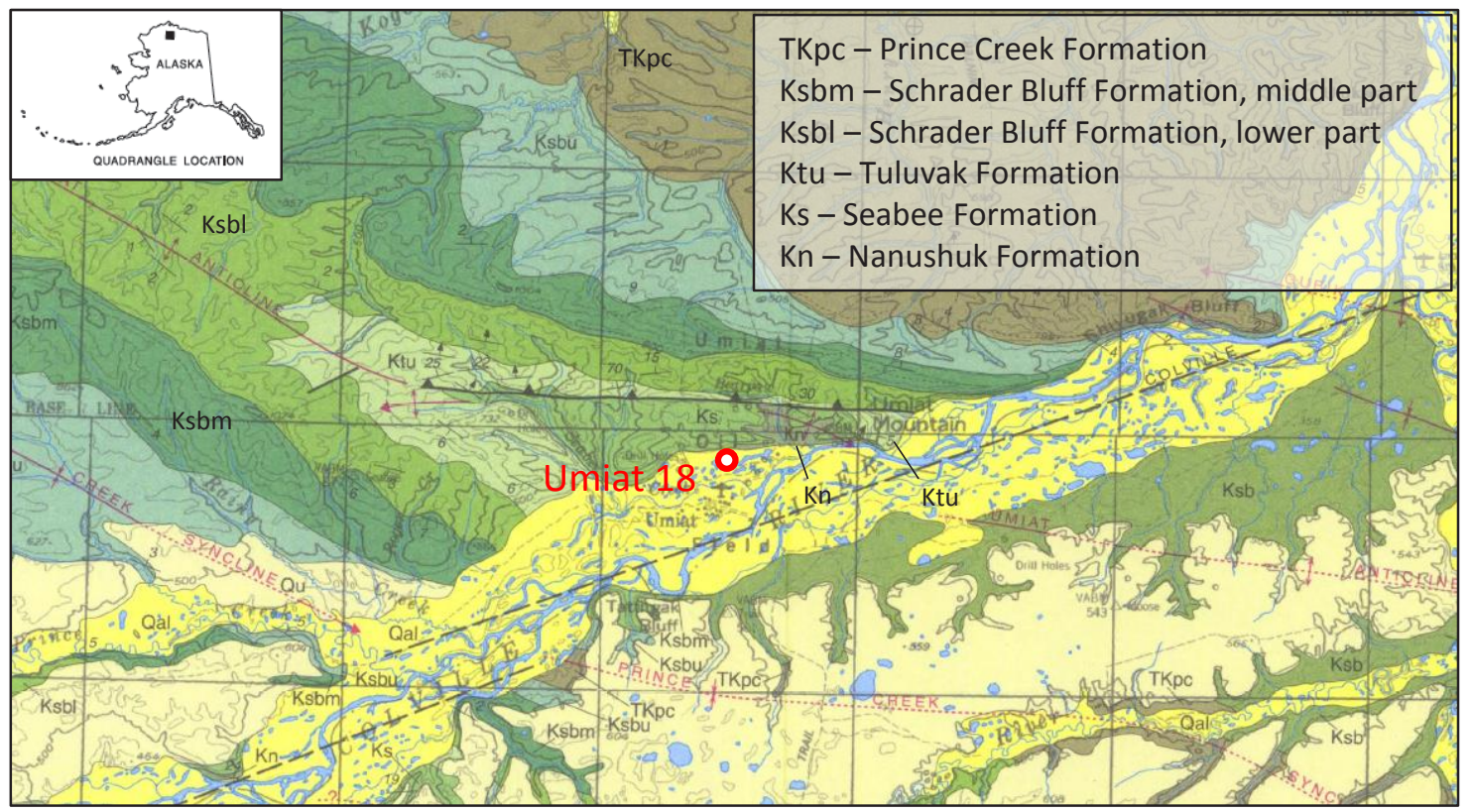

Townships provide scale ( 6 miles on a side). North is top of map.

After Mull and others (2004)

Spud Date: March 10, 2013

Completion Date: March 28, 2013

Total Depth: 2,600 feet (measured)

Objective: Confirm the presence of recoverable hydrocarbons in the lower Grandstand Formation (old nomenclature).

Results: Tested perforated interval from $775-835$ feet. No fluid production from perforated interval. Completion report provides no explanation.

Taken from Alaska Oil \& Gas Conservation Commission well history file.

API Number: 50287200280000

P \& P data obtained from well history file available from Alaska Oil \& Gas Conservation Commission. 


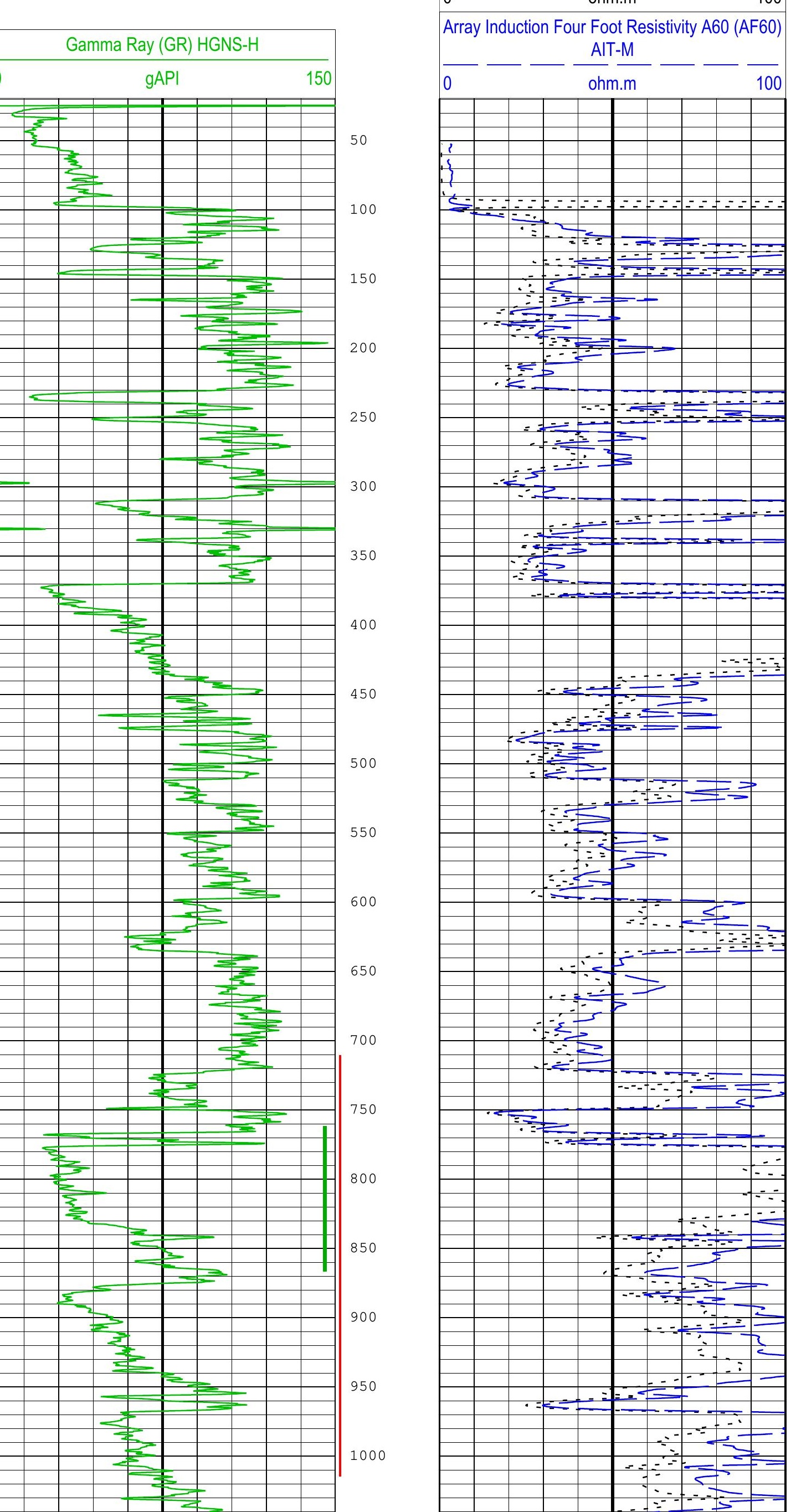

Schlumberger

Linc Umiat 18

Triple Combo, Run 1A

cored interval

core description included in this volume 


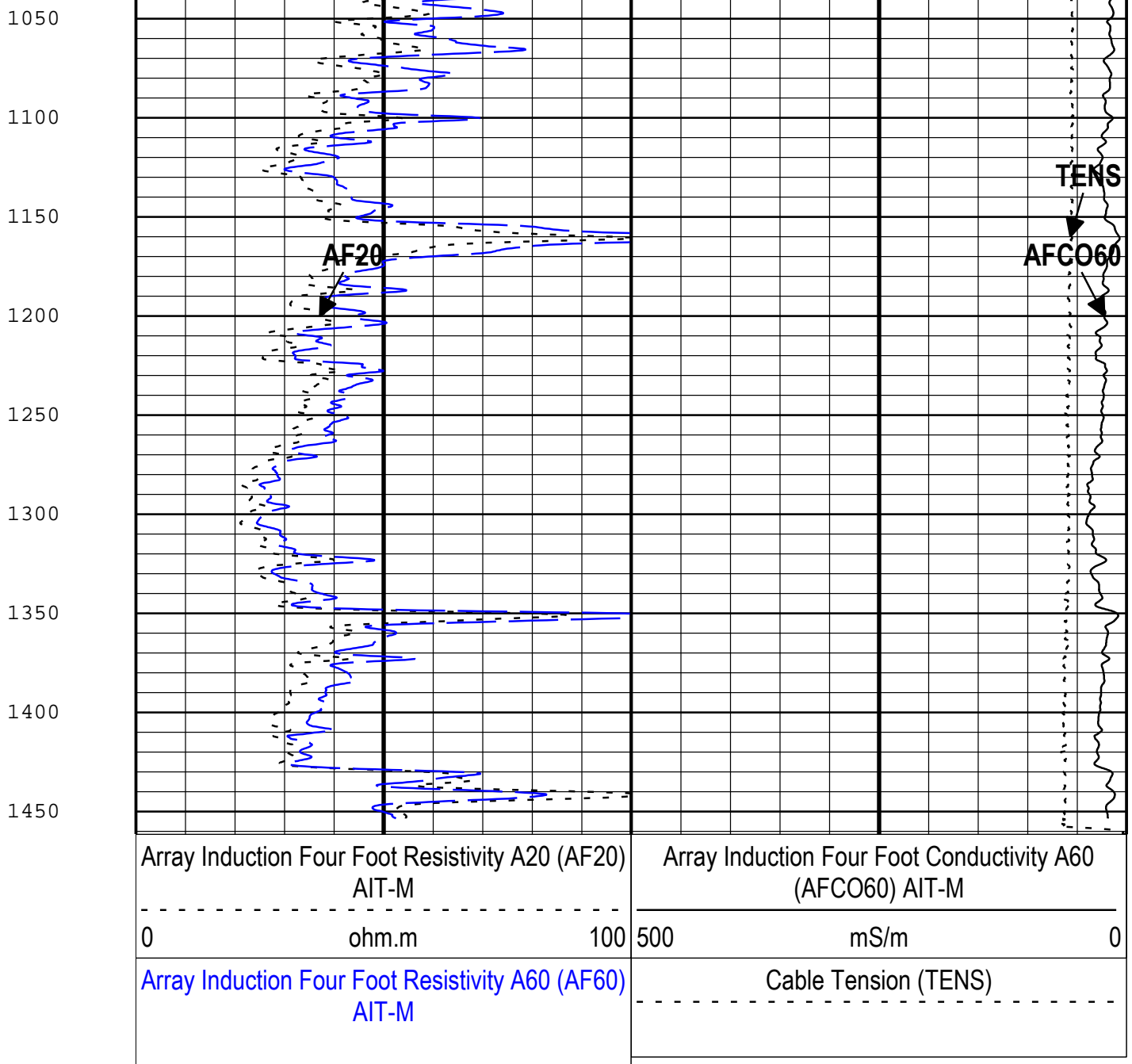




\section{Umiat 18 Conventional Core Poroperm Data API \# 50-287-20028-0000}

\begin{tabular}{|c|c|c|c|}
\hline Core Number & Depth & Ambient Porosity, \% & Air Perm, mD \\
\hline 1 & 714.40 & 5.7 & 0.03 \\
\hline 1 & 719.50 & 7.0 & 0.08 \\
\hline 1 & 727.00 & 7.8 & 0.01 \\
\hline 1 & 728.65 & 8.9 & 0.08 \\
\hline 1 & 729.35 & 8.3 & \\
\hline 1 & 741.00 & 5.3 & 0.00 \\
\hline 1 & 744.00 & 4.7 & 0.01 \\
\hline 1 & 750.00 & 15.3 & 94.30 \\
\hline 1 & 752.35 & 8.7 & \\
\hline 1 & 761.15 & 11.9 & 1.08 \\
\hline 1 & 765.45 & 8.2 & 0.10 \\
\hline 1 & 766.55 & 7.9 & 0.06 \\
\hline 1 & 769.00 & 17.1 & 497.00 \\
\hline 1 & 769.70 & 17.6 & 280.00 \\
\hline 2 & 771.95 & 16.4 & 130.00 \\
\hline 2 & 776.20 & 6.6 & 0.02 \\
\hline 2 & 778.45 & 16.1 & 152.00 \\
\hline 2 & 781.50 & 17.0 & 149.00 \\
\hline 2 & 781.70 & 16.4 & 104.00 \\
\hline 2 & 785.00 & 16.2 & 83.40 \\
\hline 2 & 790.15 & 12.0 & 6.14 \\
\hline 2 & 796.65 & 10.1 & \\
\hline 2 & 799.15 & 17.5 & 216.00 \\
\hline 2 & 799.30 & 16.8 & 158.00 \\
\hline 2 & 803.05 & 17.5 & 152.00 \\
\hline 2 & 806.00 & 17.71 & 269.00 \\
\hline 2 & 809.15 & 17.66 & 237.00 \\
\hline 2 & 811.55 & 8.0 & 0.07 \\
\hline 2 & 812.20 & 13.7 & 20.80 \\
\hline 2 & 814.25 & 17.2 & \\
\hline 2 & 831.25 & 14.0 & 31.00 \\
\hline 3 & 844.20 & 9.7 & 0.20 \\
\hline 3 & 847.00 & 9.5 & 0.09 \\
\hline 3 & 850.00 & 9.3 & 0.06 \\
\hline 3 & 861.00 & 8.9 & 0.03 \\
\hline 3 & 862.50 & 9.8 & 0.04 \\
\hline 3 & 872.30 & 4.7 & 0.01 \\
\hline 3 & 877.20 & 6.1 & 0.01 \\
\hline 3 & 877.90 & 7.2 & 0.02 \\
\hline
\end{tabular}




\begin{tabular}{|c|c|c|c|}
\hline 3 & 878.50 & 9.7 & 0.26 \\
\hline 3 & 879.50 & 13.9 & 21.30 \\
\hline 3 & 881.00 & 12.3 & 6.12 \\
\hline 3 & 883.55 & 13.5 & 21.40 \\
\hline 3 & 888.00 & 15.3 & 102.00 \\
\hline 3 & 889.00 & 15.5 & 81.90 \\
\hline 3 & 892.05 & 17.6 & \\
\hline 3 & 893.85 & 14.5 & 18.10 \\
\hline 4 & 896.60 & 13.6 & 26.00 \\
\hline 4 & 898.40 & 16.1 & 93.70 \\
\hline 4 & 900.70 & 15.5 & 66.40 \\
\hline 4 & 902.10 & 13.7 & 11.80 \\
\hline 4 & 904.40 & 11.6 & 2.12 \\
\hline 4 & 907.00 & 13.5 & 12.00 \\
\hline 4 & 908.00 & 14.08 & 29.90 \\
\hline 4 & 917.35 & 12.9 & 7.69 \\
\hline 4 & 920.00 & 11.9 & 3.10 \\
\hline 4 & 924.20 & 9.6 & 0.28 \\
\hline 4 & 927.00 & 11.4 & 1.67 \\
\hline 4 & 936.45 & 9.2 & 0.29 \\
\hline 4 & 942.00 & 7.5 & 0.06 \\
\hline 4 & 953.25 & 18.1 & \\
\hline 5 & 955.60 & 6.1 & 0.00 \\
\hline 5 & 959.45 & 11.8 & 4.13 \\
\hline 5 & 969.15 & 8.6 & \\
\hline 5 & 970.25 & 10.9 & 0.20 \\
\hline 5 & 971.65 & 11.8 & 0.30 \\
\hline 5 & 973.55 & 13.1 & 1.69 \\
\hline 5 & 977.05 & 13.9 & 2.83 \\
\hline 5 & 980.25 & 11.9 & 0.25 \\
\hline 5 & 981.00 & 11.07 & 0.62 \\
\hline 5 & 981.60 & 12.1 & 0.99 \\
\hline 5 & 986.10 & 10.6 & 0.40 \\
\hline 5 & 986.80 & 11.4 & 0.91 \\
\hline 5 & 991.70 & 10.7 & 0.48 \\
\hline 5 & 995.55 & 9.5 & 0.09 \\
\hline 5 & 999.10 & 7.5 & 0.02 \\
\hline 5 & 1000.65 & 9.4 & 0.06 \\
\hline 5 & 1011.90 & 9.5 & 0.11 \\
\hline
\end{tabular}




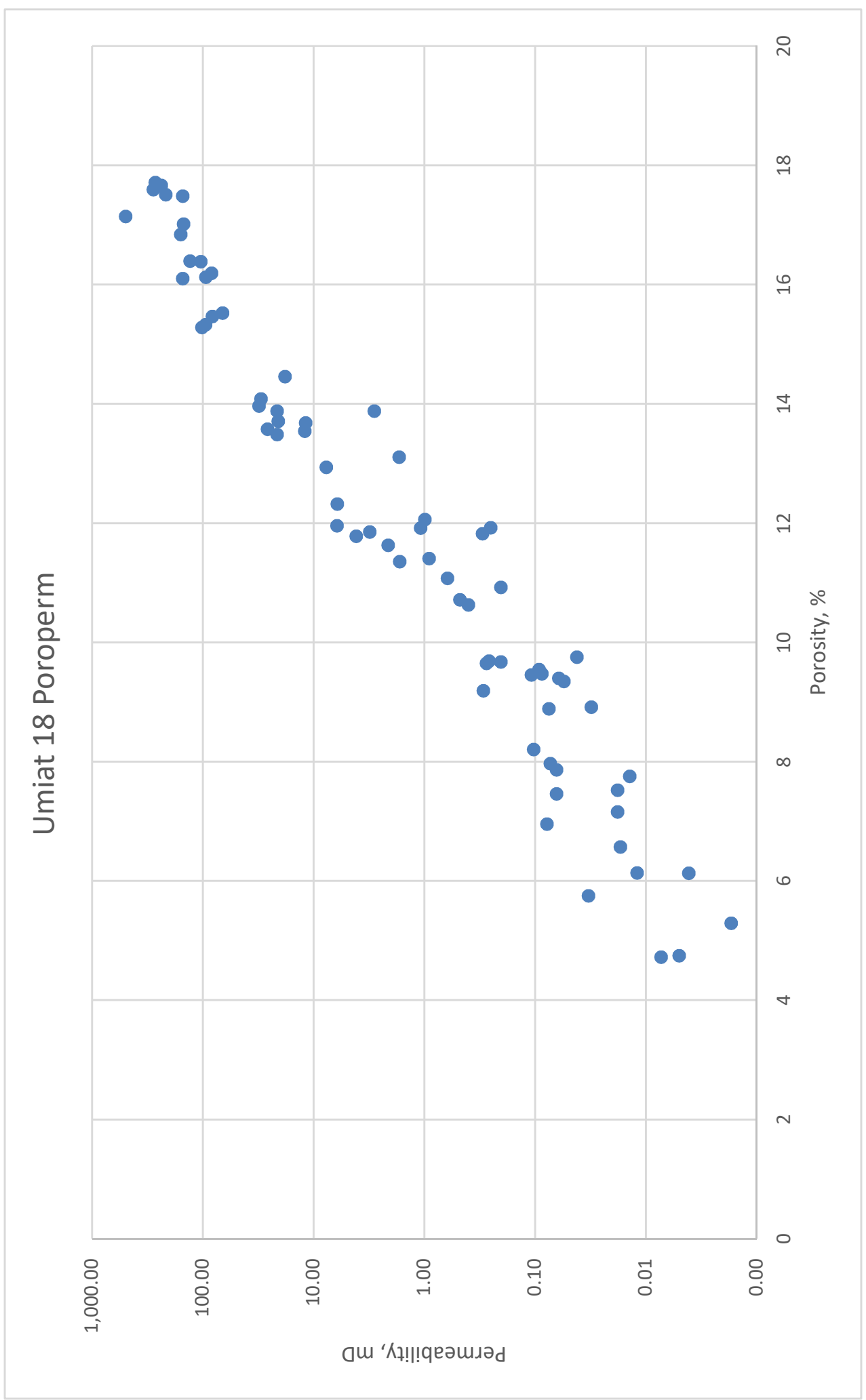


Umiat 18

Depth: 868-761 feet

Cores 1 (partial), 2,

and 3 (partial)

\begin{tabular}{|c|c|c|c|}
\hline $\begin{array}{l}\dot{0} \\
0 \\
0 \\
0\end{array}$ & 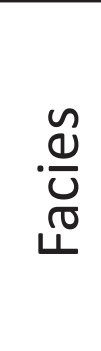 & 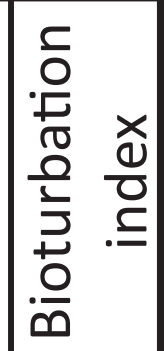 & Graphic Log \\
\hline
\end{tabular}
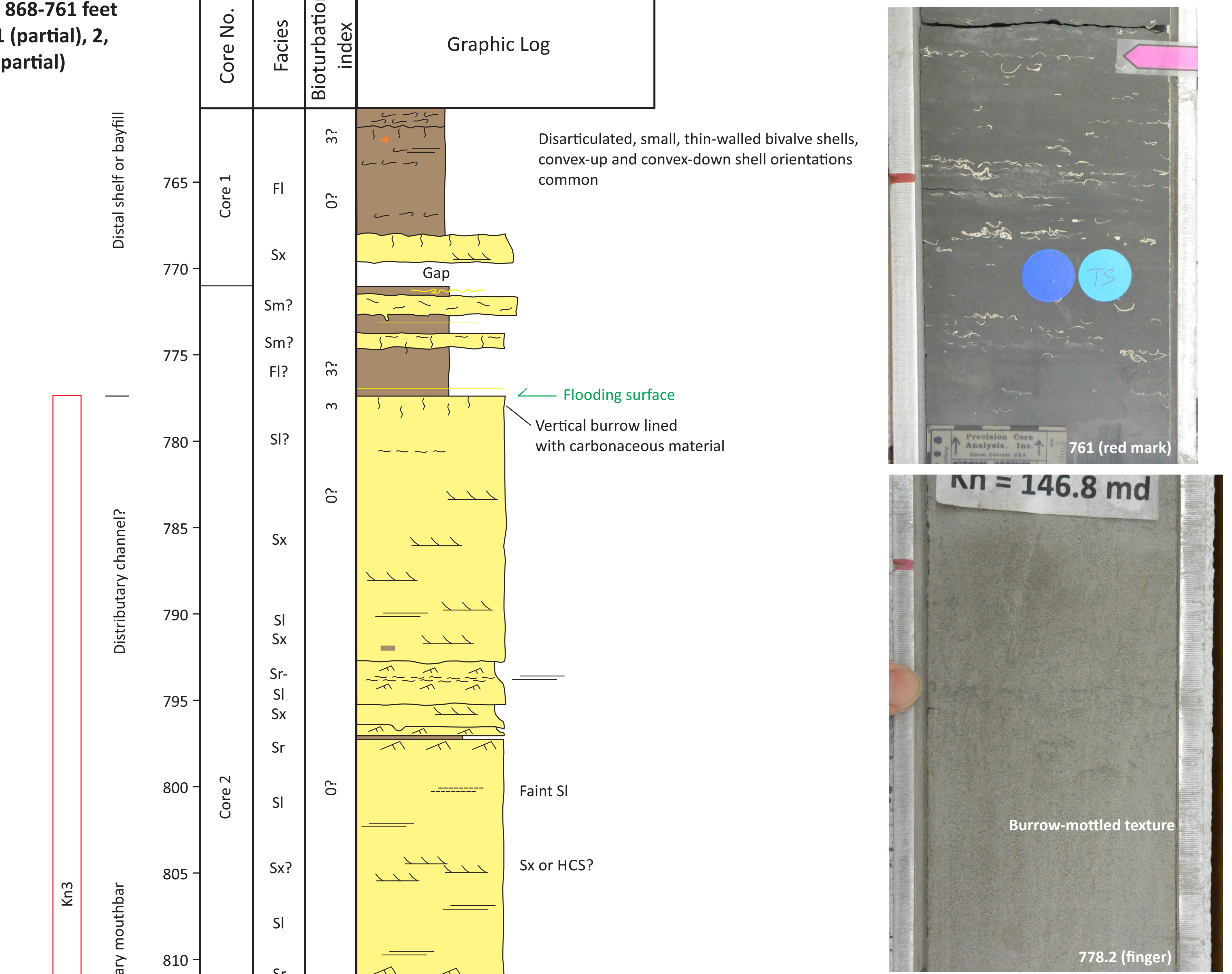
base parasequence
approximately 877 feet 竞

$\mathrm{Sr}$

$\pi$ ?

ก.

$\pi \stackrel{i}{\underline{n} \Lambda}$

$820-$

$\mathrm{SI}$

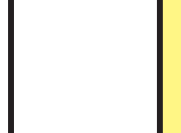

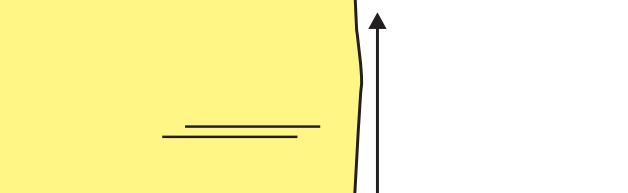

825

$(m$

Abundant

coring-induced

fractures

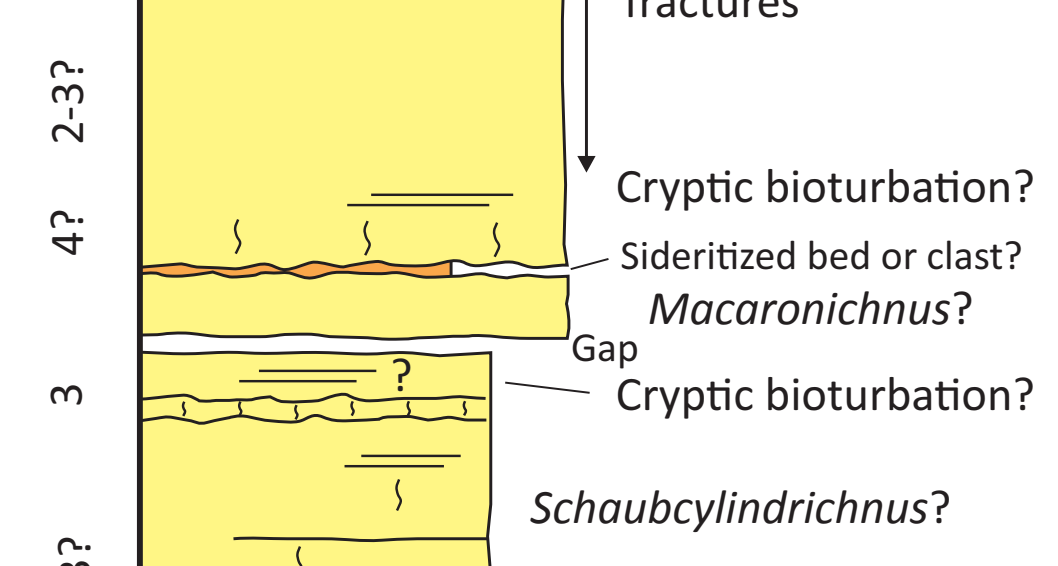

n.

$\sim \sim \ldots$ ?

845

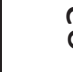

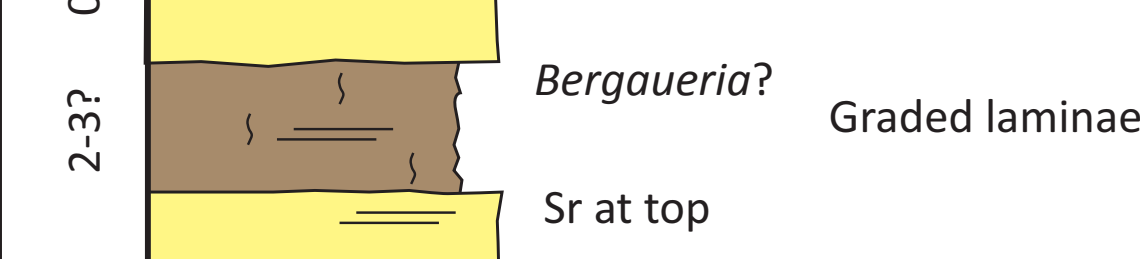

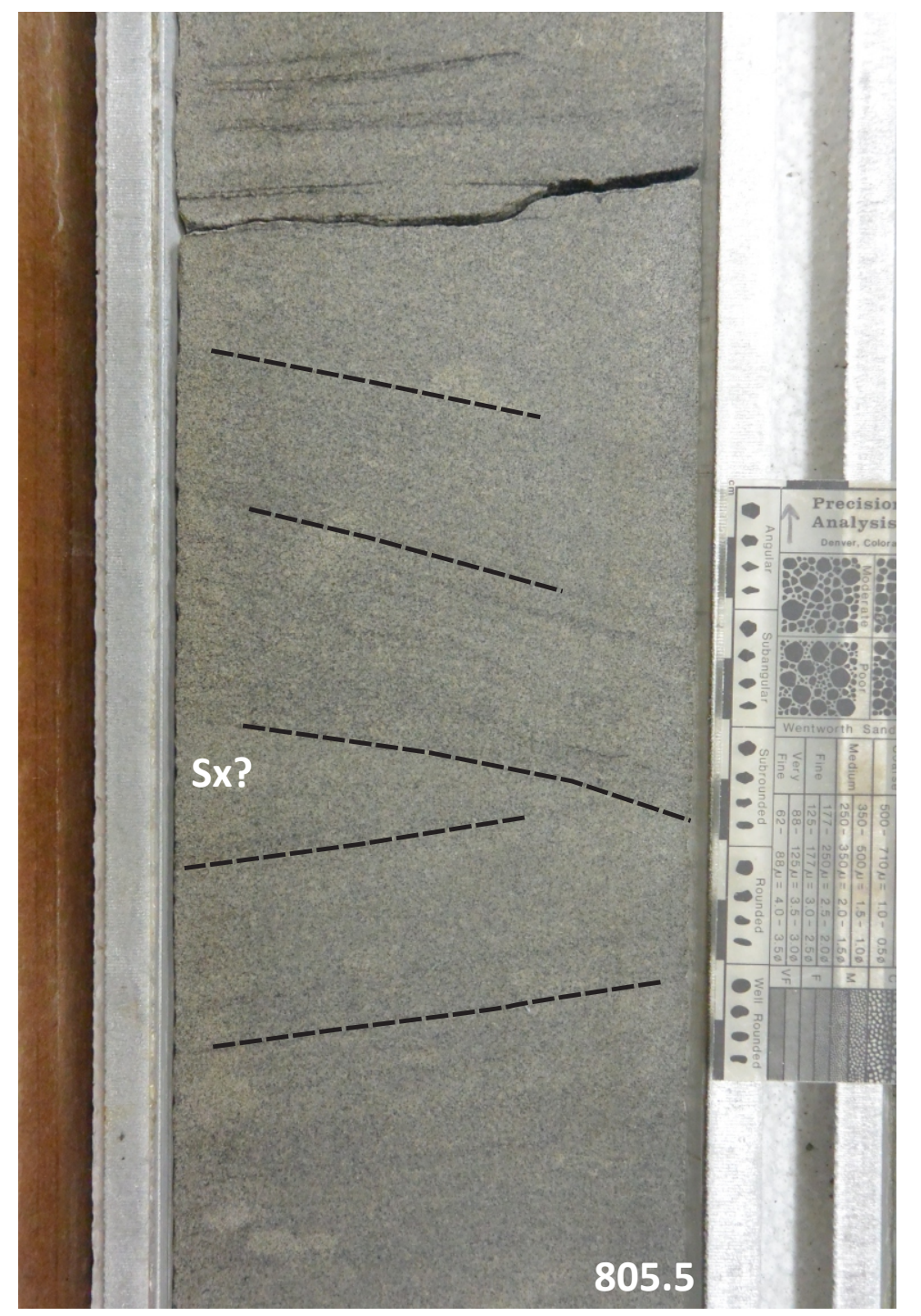

\%

$\rightarrow$ ?

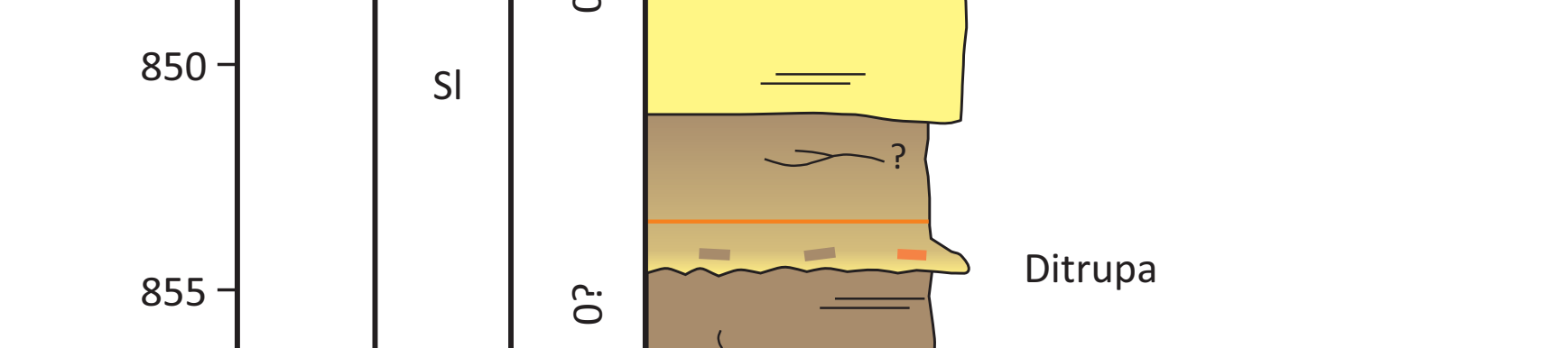

$\frac{\sqrt{5}}{\frac{\pi}{0}}$

Palaeophycus

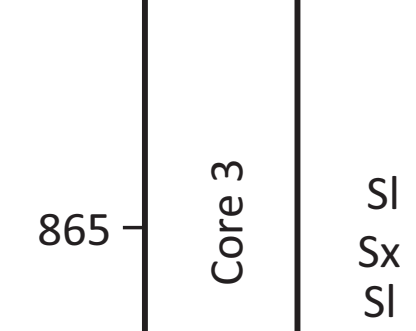

feet

每

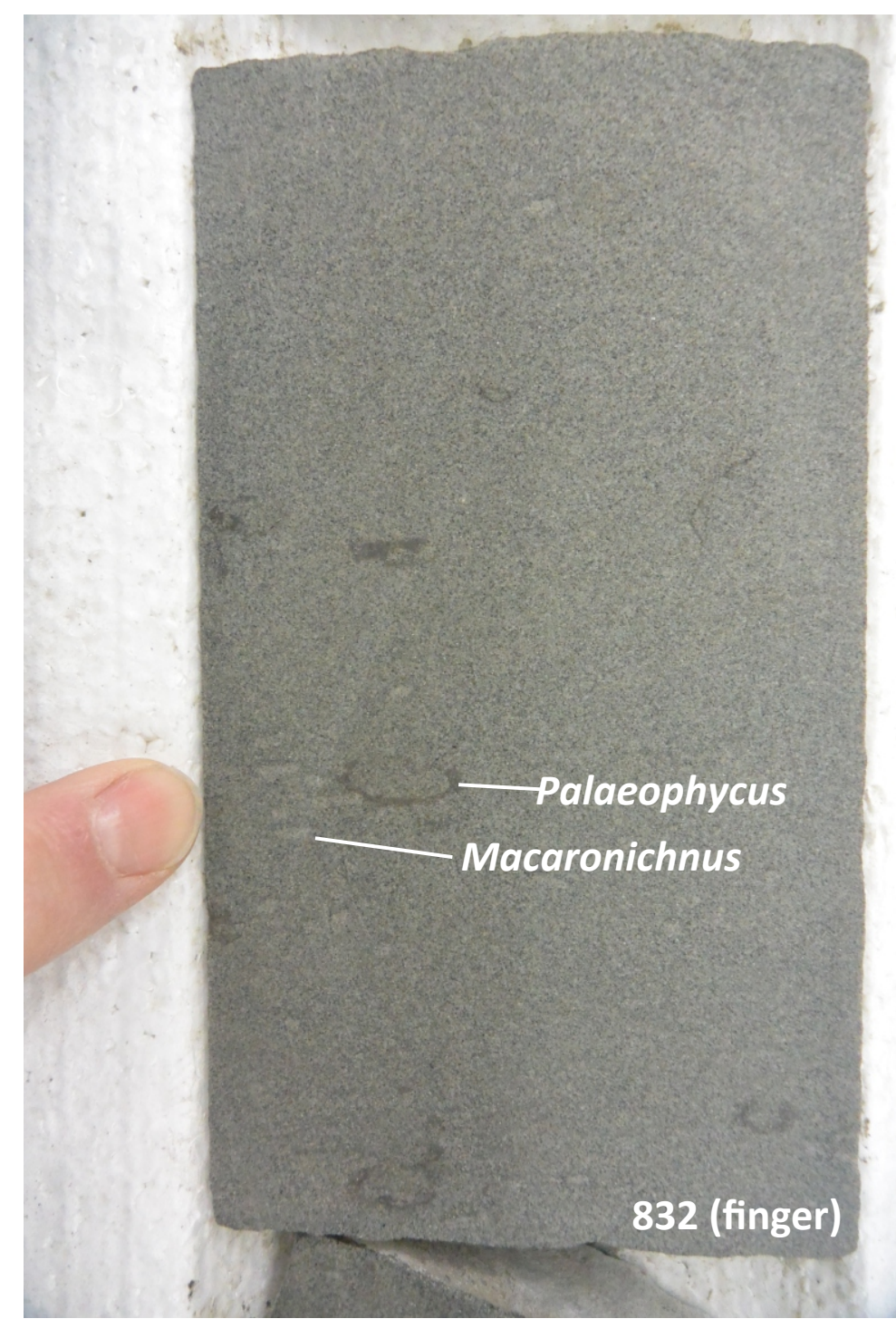




\section{Fish Creek Test Well 1}

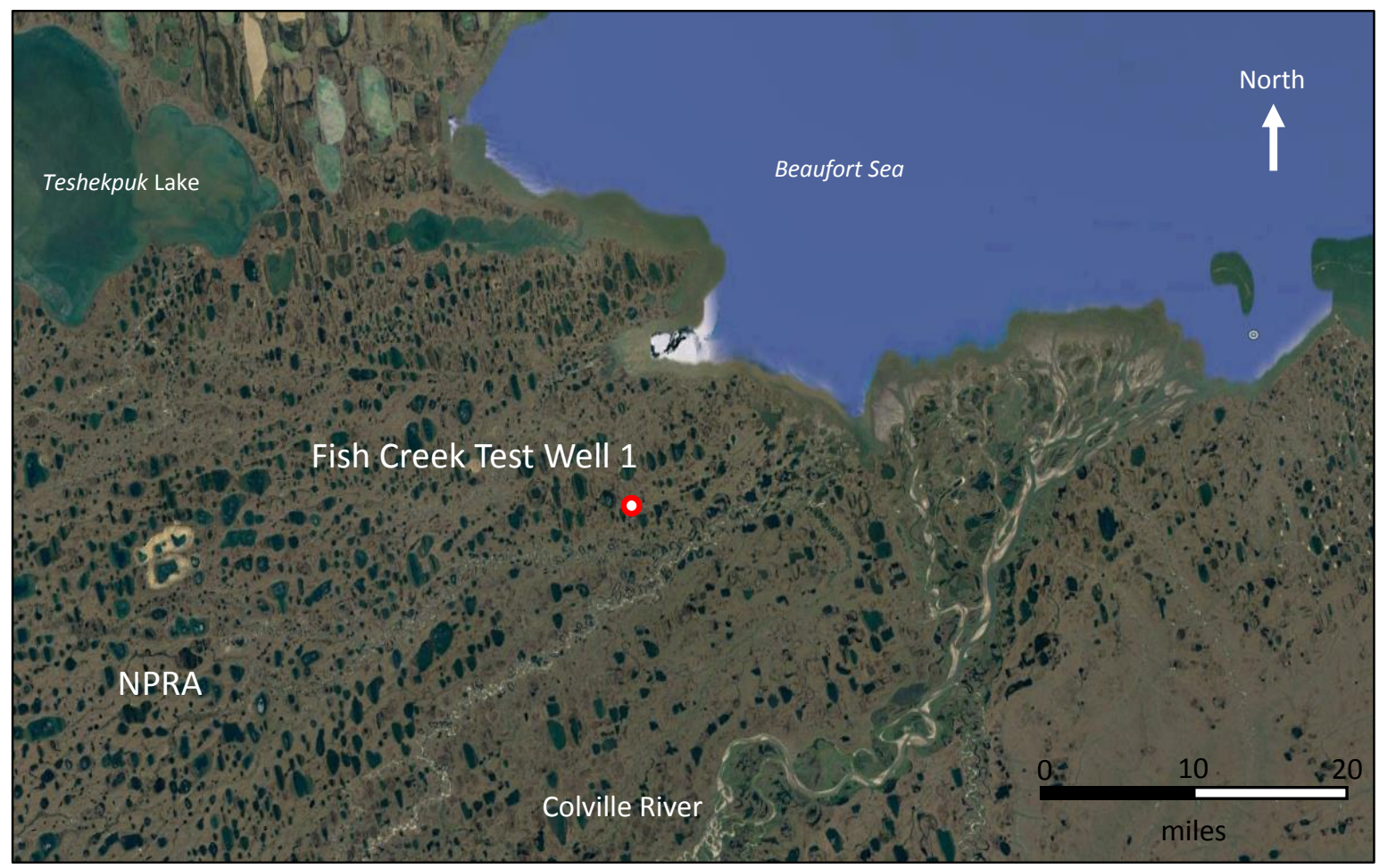

Spud Date: May 14, 1949

Completion Date: September 4, 1949

Total Depth: 7,020 feet

Objective: To "disclose the stratigraphy of the northeastern part of the reserve" and to test for the presence of petroleum-bearing strata near the center of a gravity anomaly. The well is located $1 \frac{1}{2}$ mile northeast of an oil seep.

Results: Encountered numerous oil shows. After completion, "yielded on average 12 barrels of oil per day when pumped."

Taken from Robinson and Collins (1959).

API Number: 5003100010000

Seismic location map and 2D seismic line are publicly available U.S. Geological Survey data. Seismic interpretation was done by Holly Fair (Alaska Division of Oil \& Gas). 


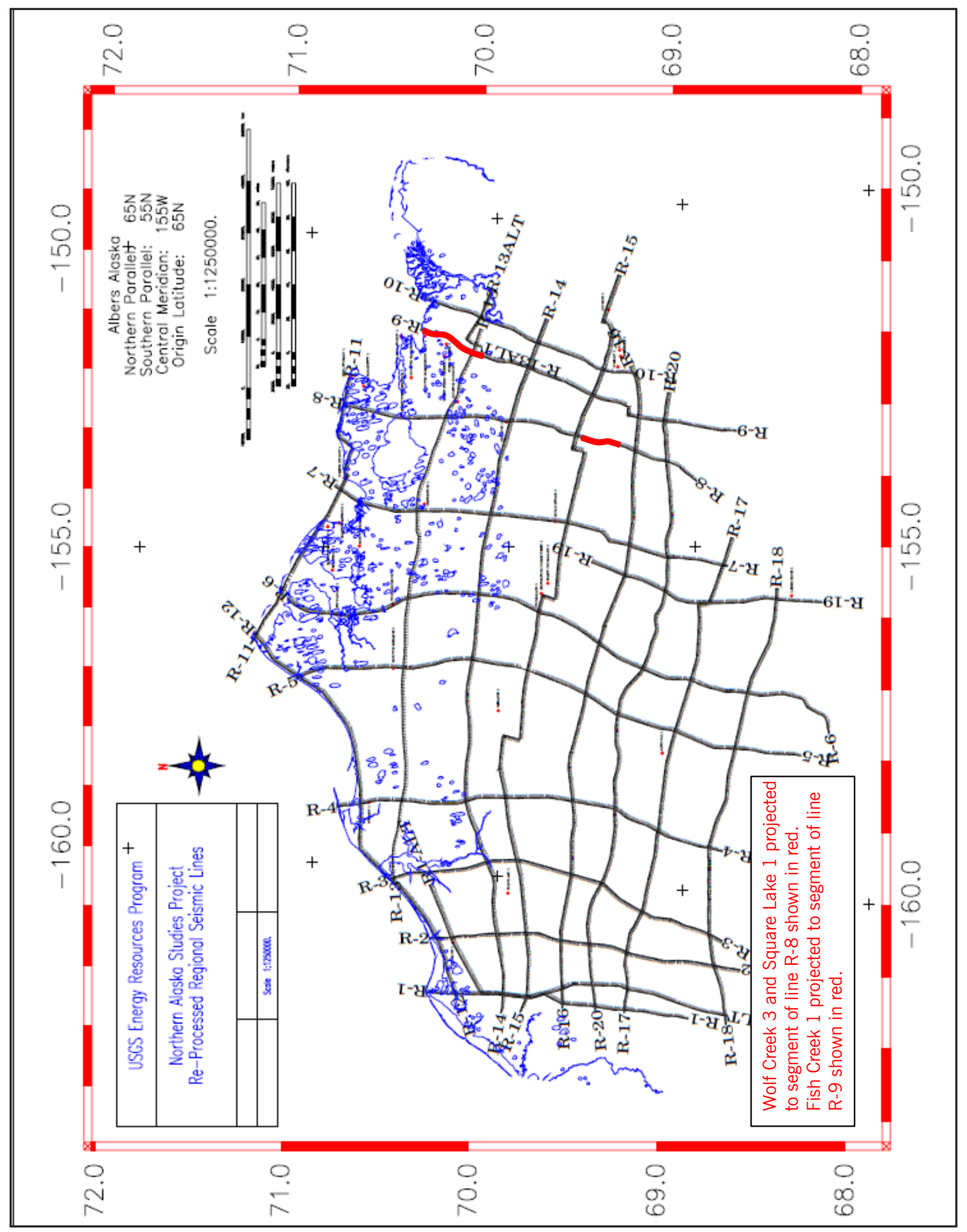




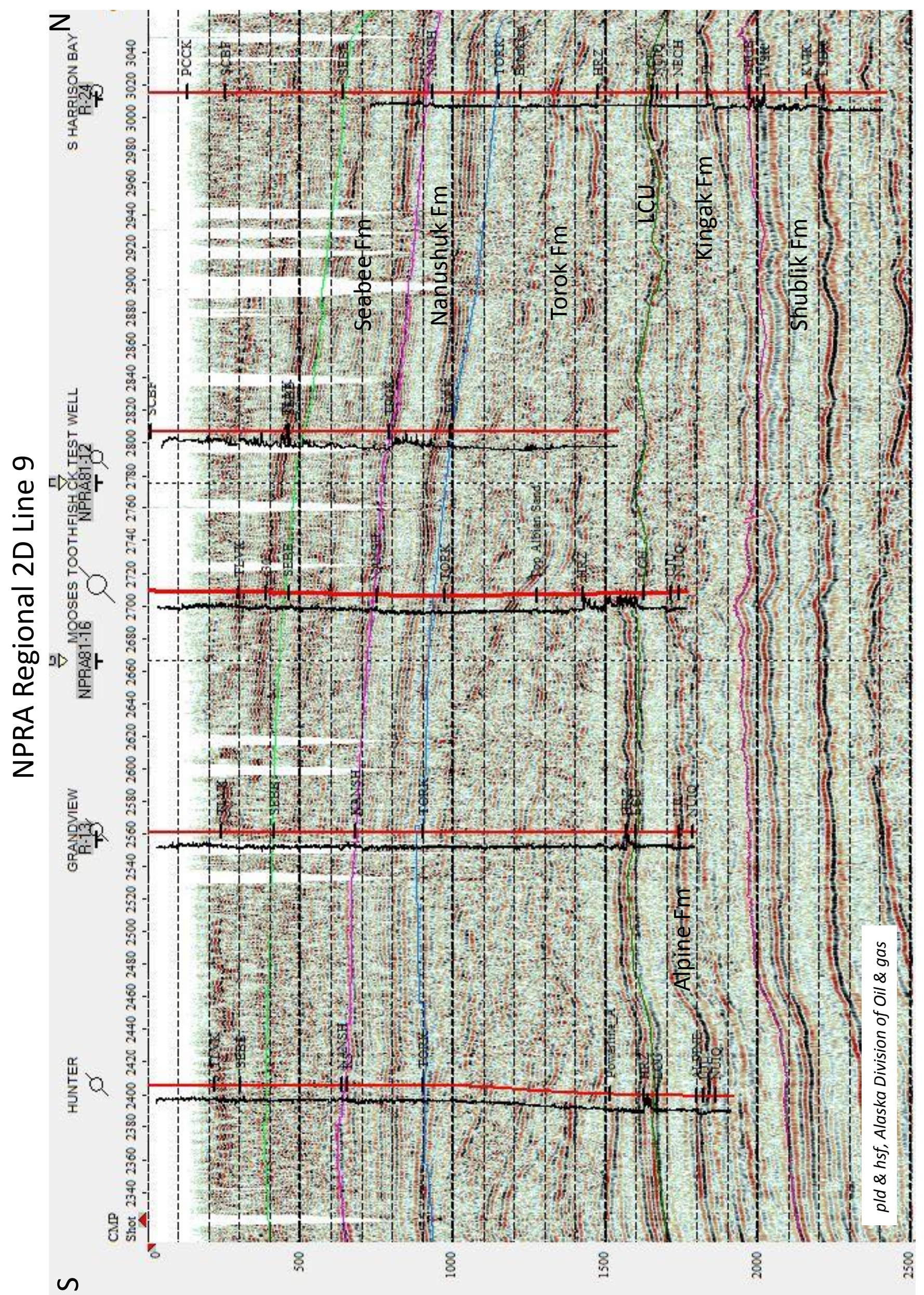


KB: 32.0000 Long: 151.870 Lat: $70.300 \quad$ Date Plotted: $5 / 23 / 01$

\begin{tabular}{ll|lll} 
Min Depth: & 187.0 & Max Depth: & 7020.0 & UWI: \\
$50-103-10001$
\end{tabular}
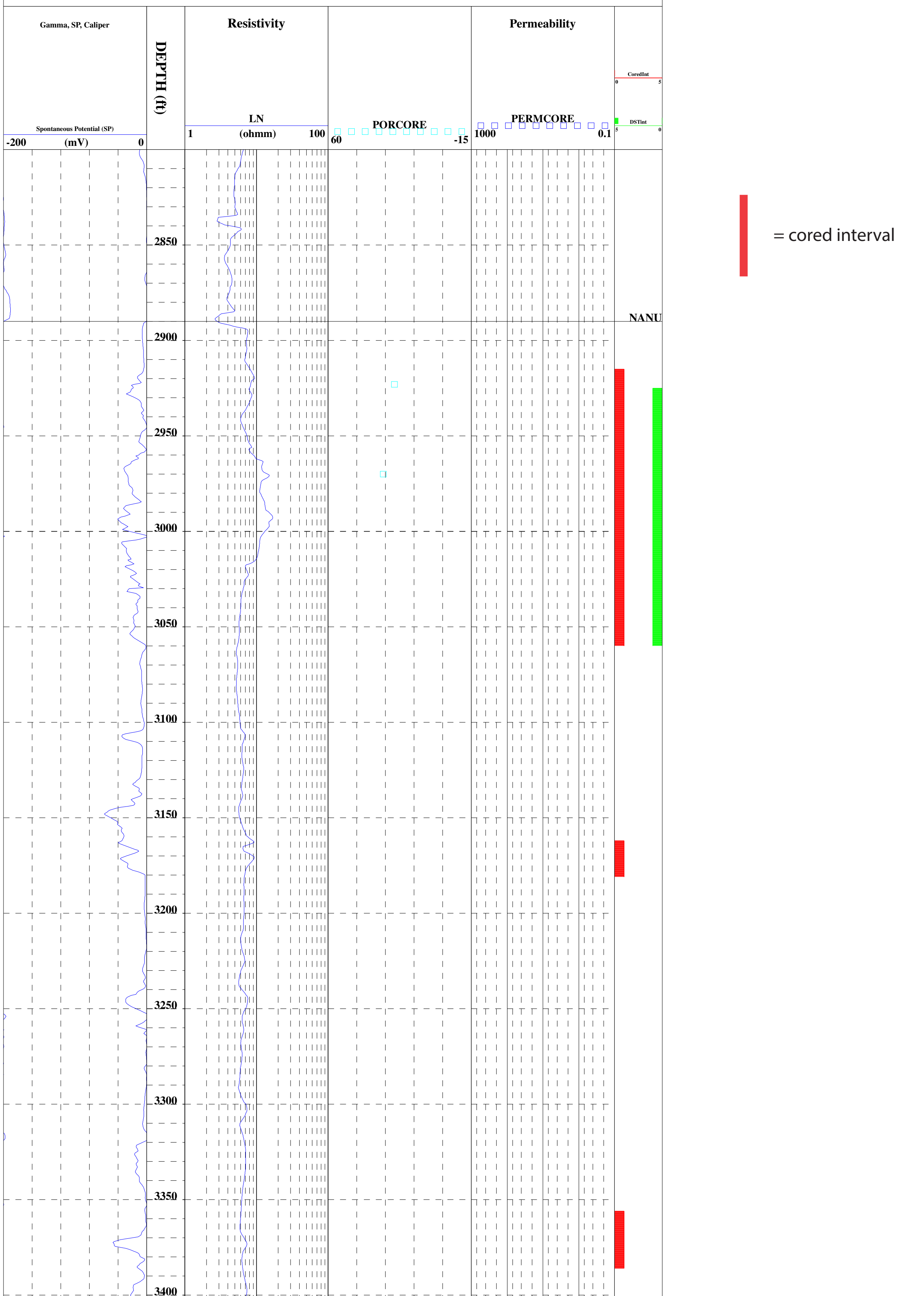

-

3450

3500

3600

3650

3700.

3750

$\left\{\begin{array}{c}- \\ - \\ - \\ - \\ -\end{array}\right.$

3850 -

3900.

--
.--
-
-
-
-

3950

(-...

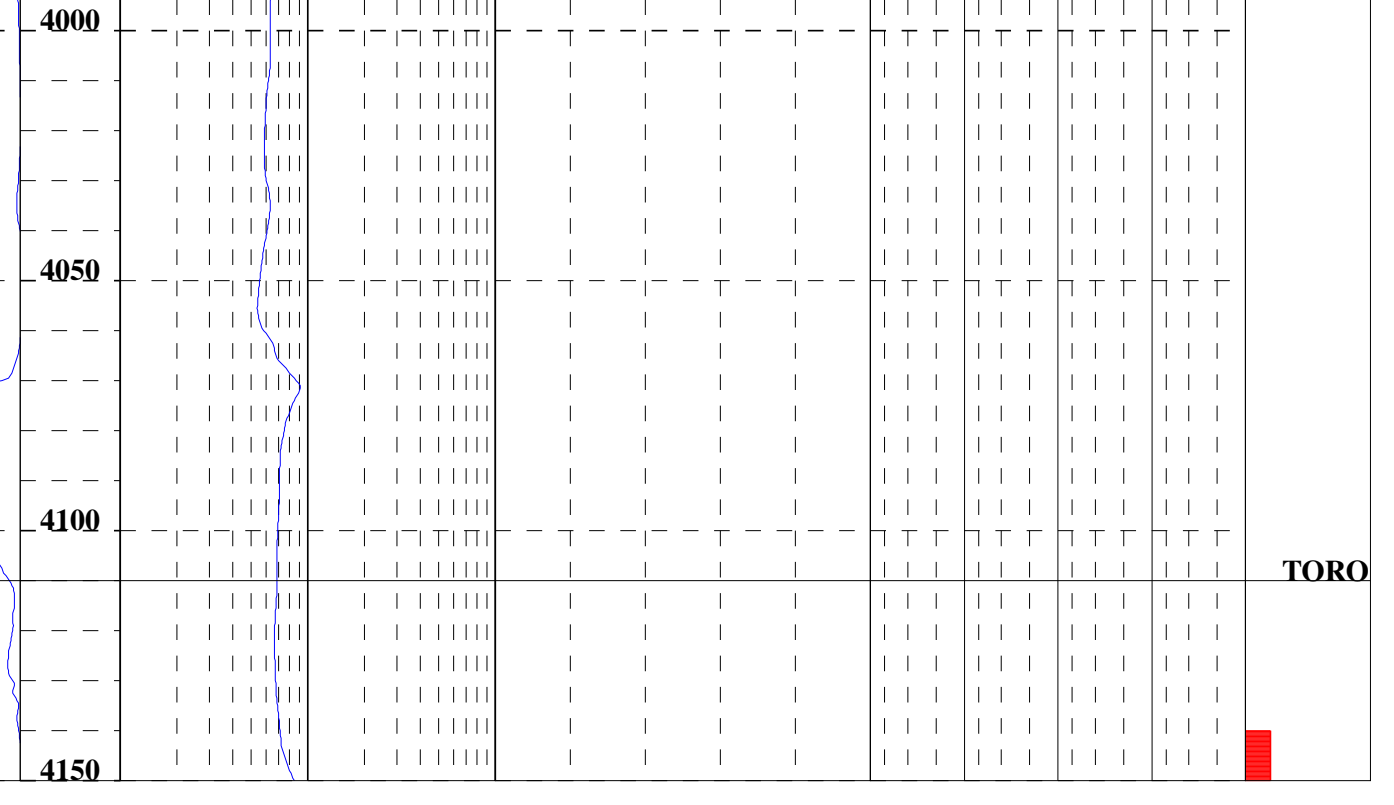



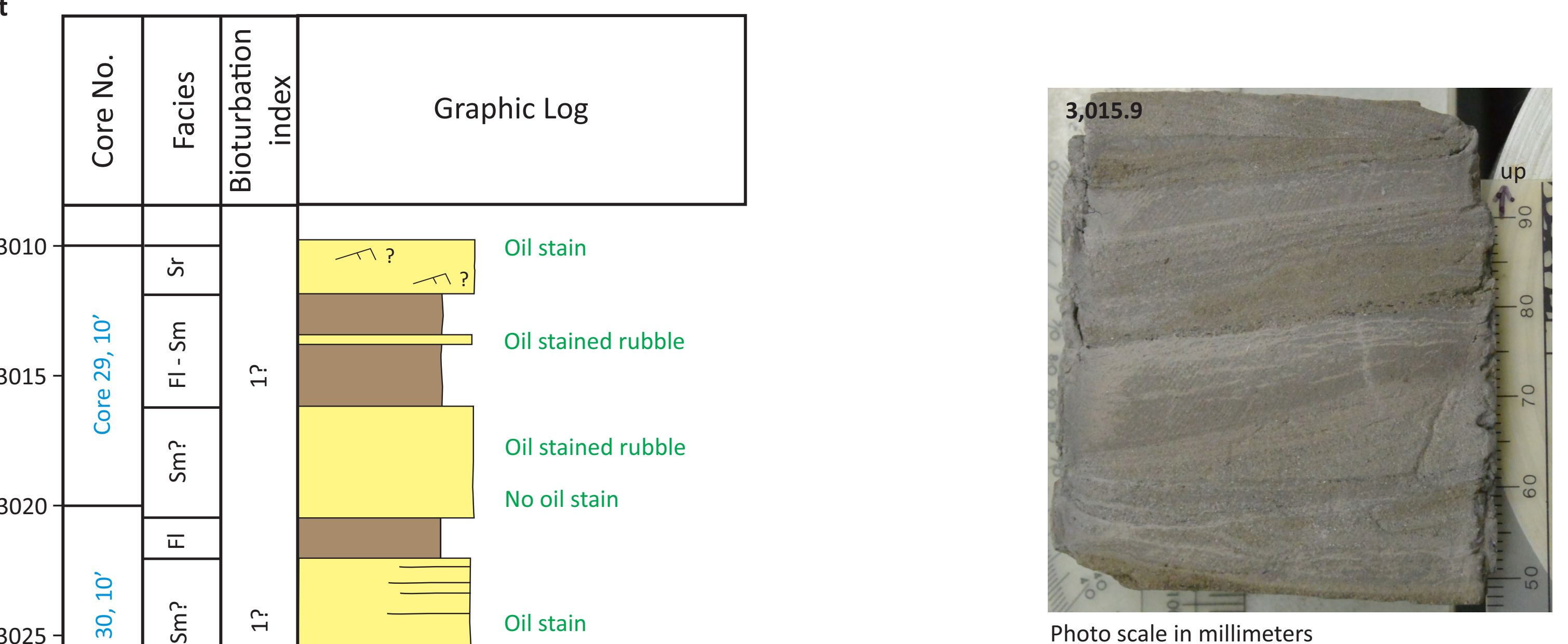

Photo scale in millimeters

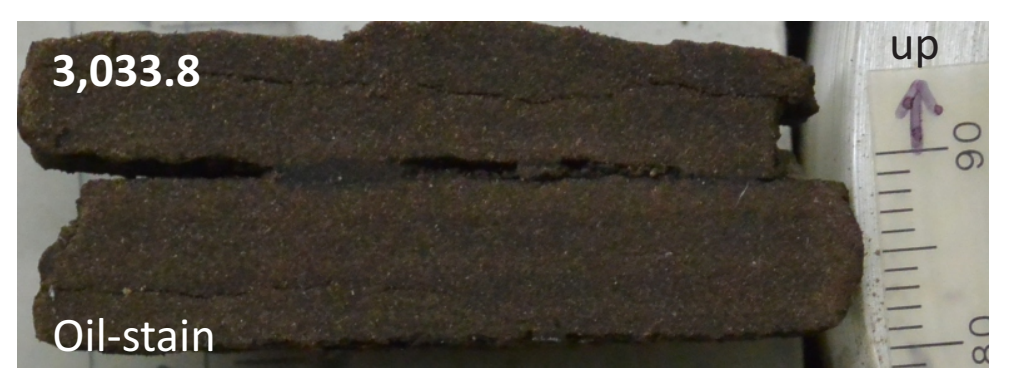

Photo scale in millimeters

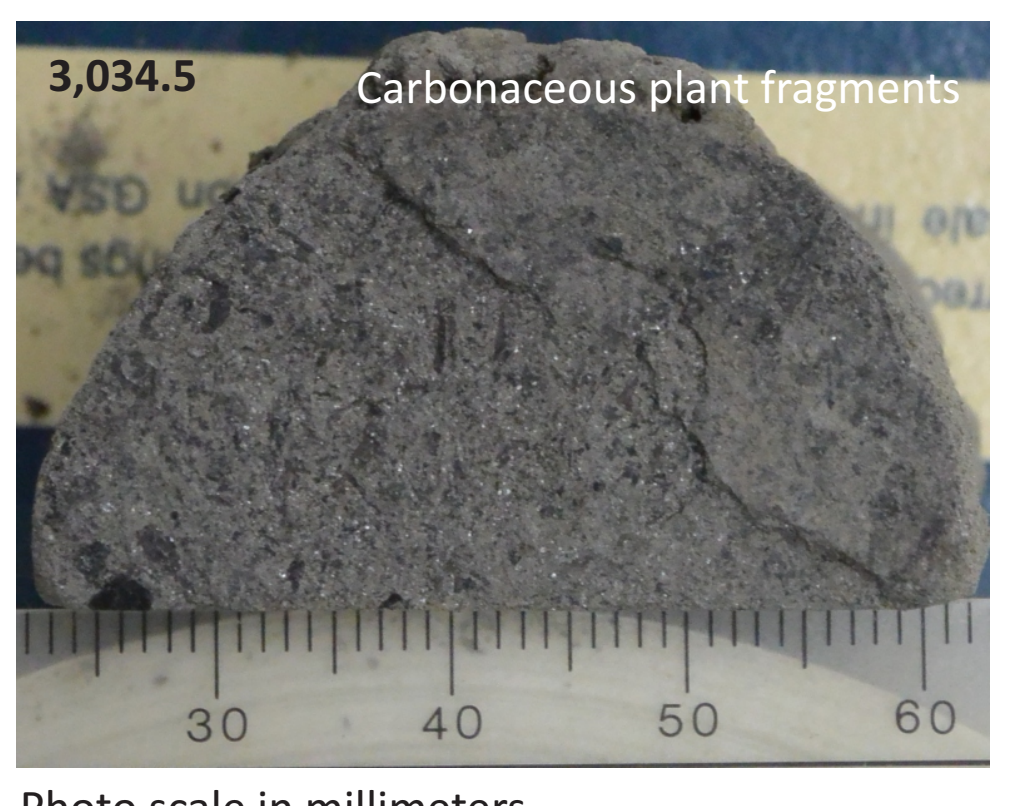

Photo scale in millimeters

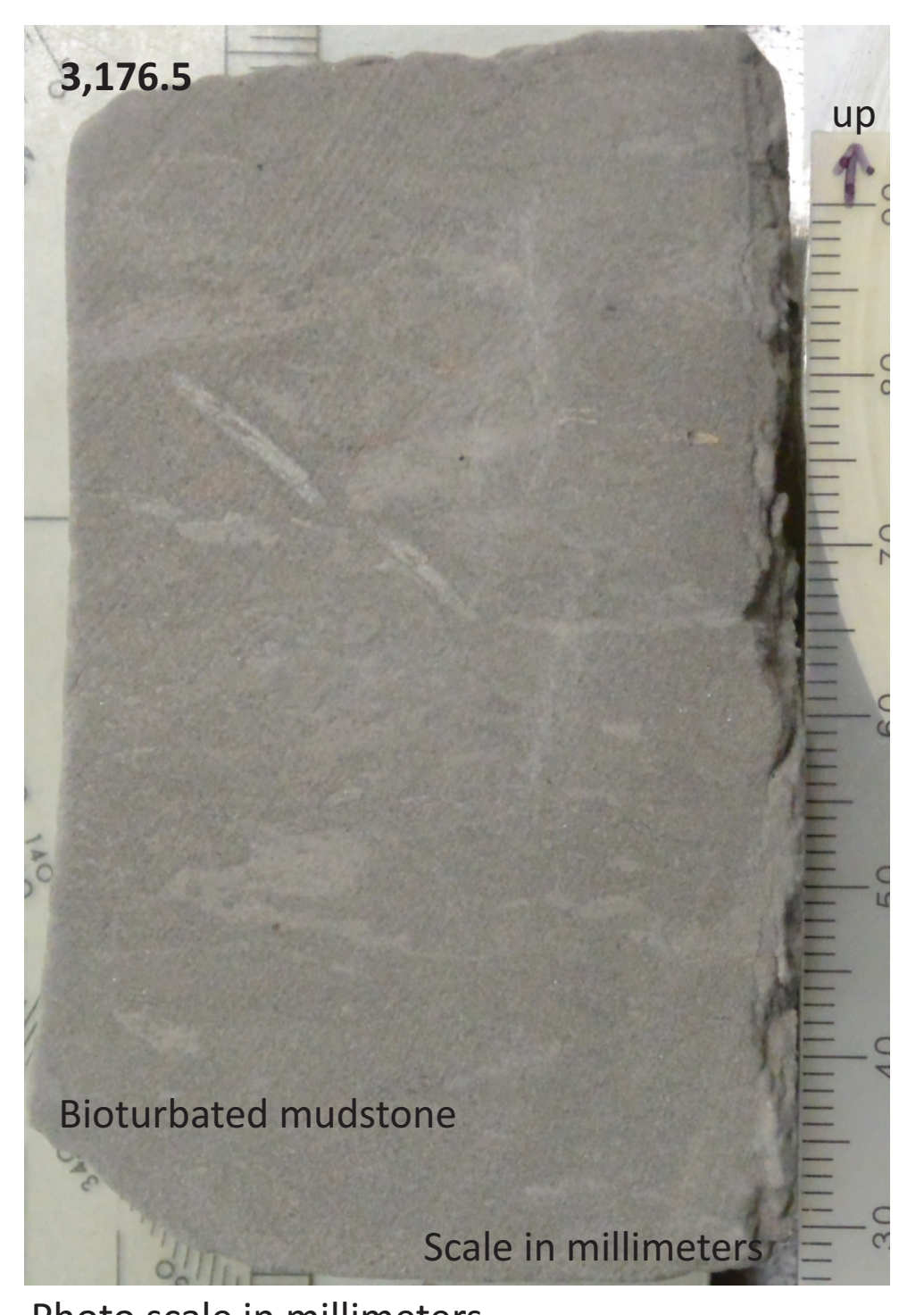

Photo scale in millimeters

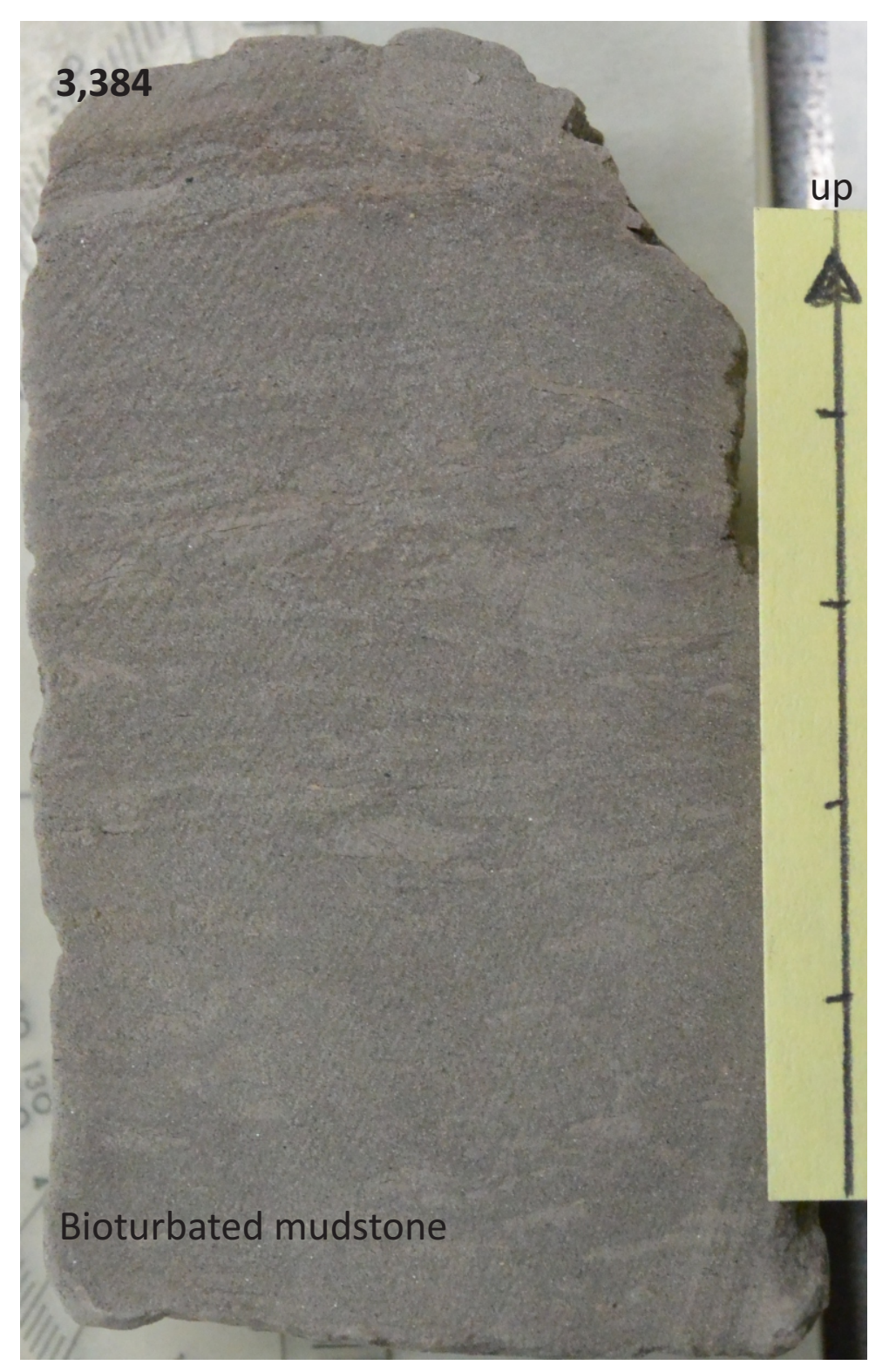

Photo scale in centimeters 

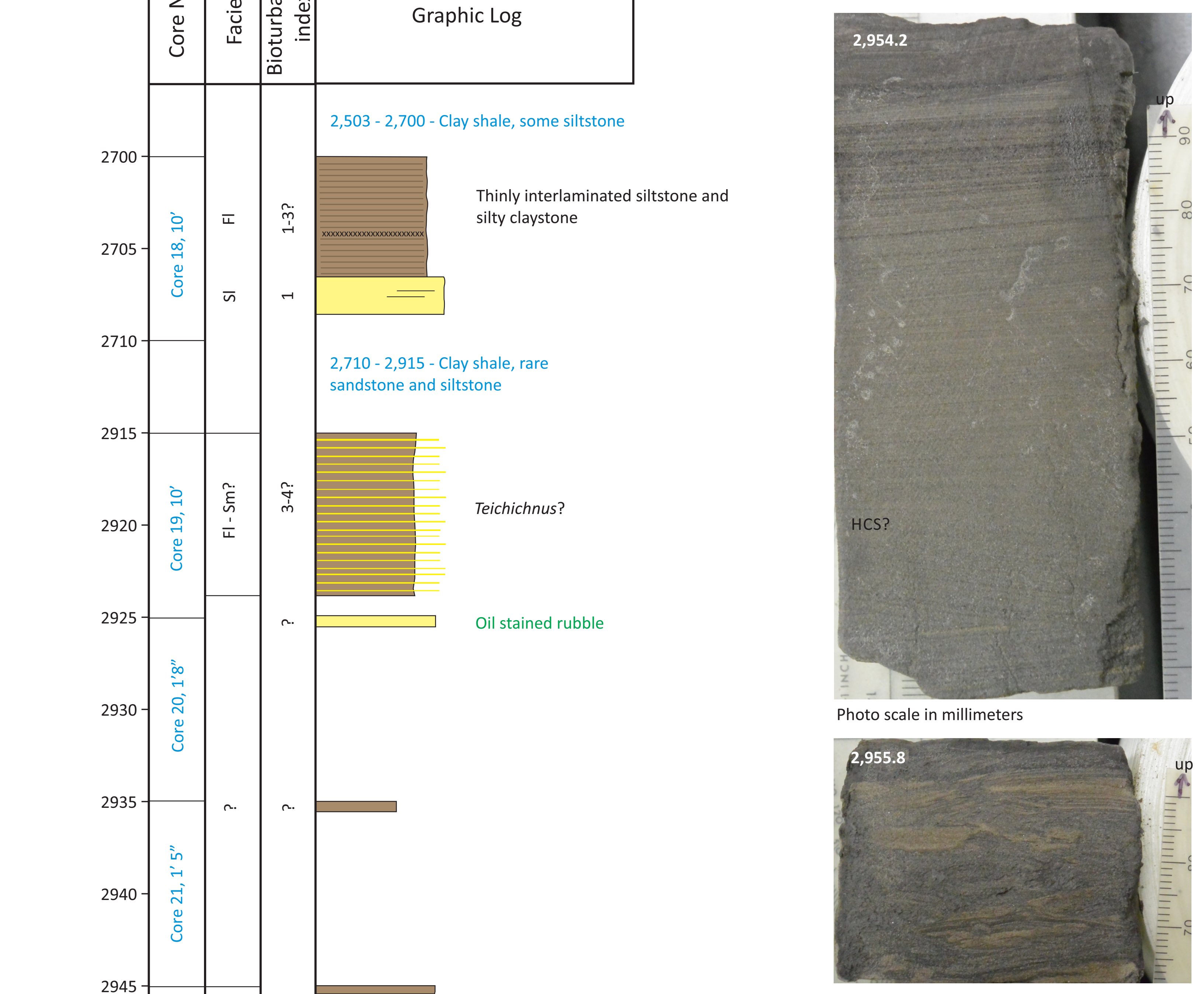

$\frac{0}{\frac{1}{c}}$
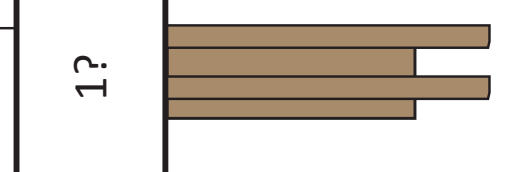

Photo scale in millimeters

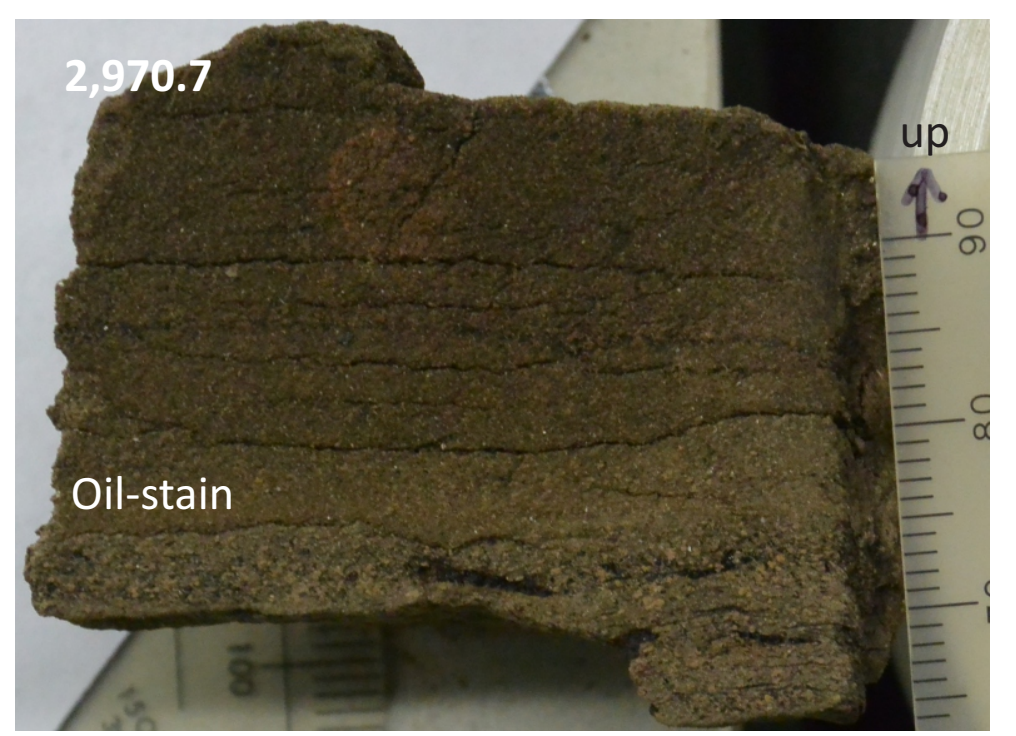

Photo scale in millimeters

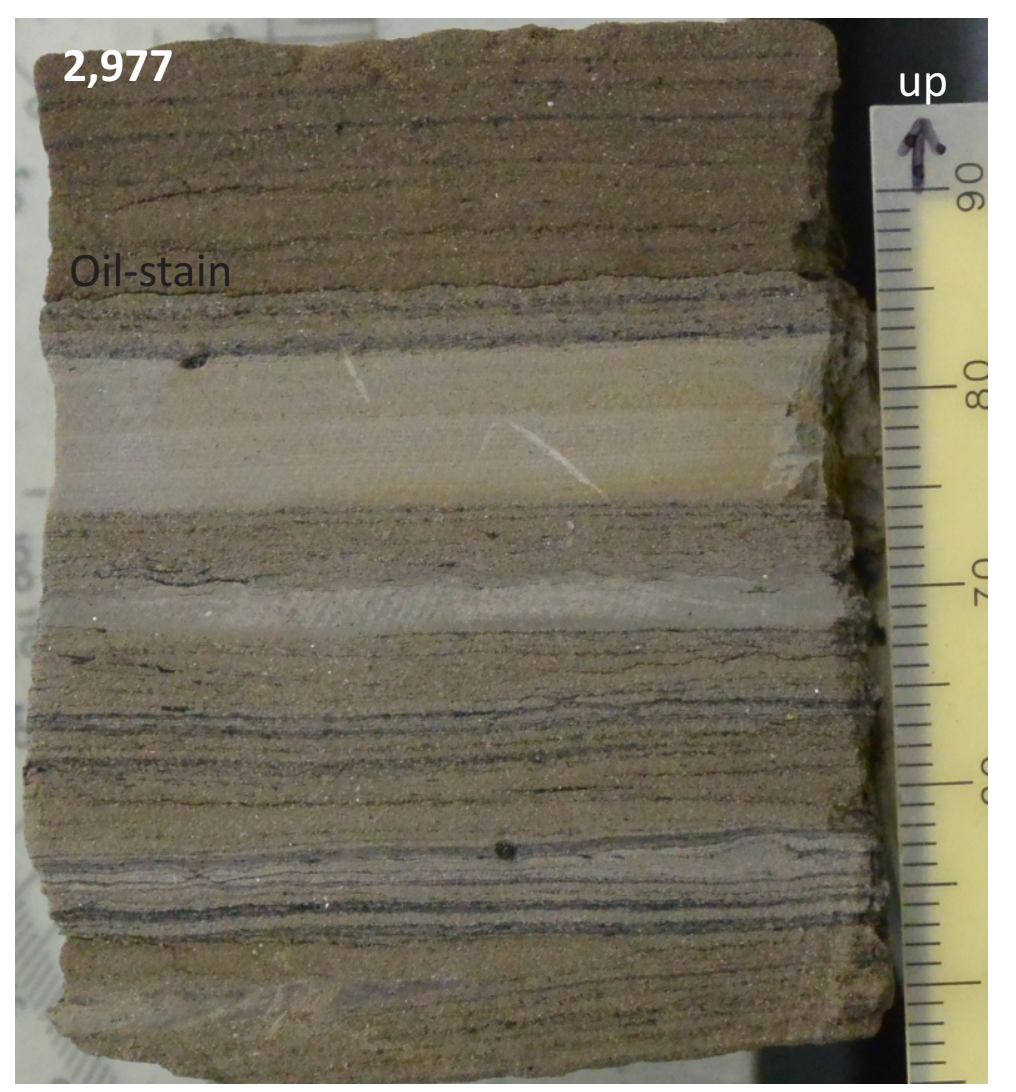

Photo scale in millimeters

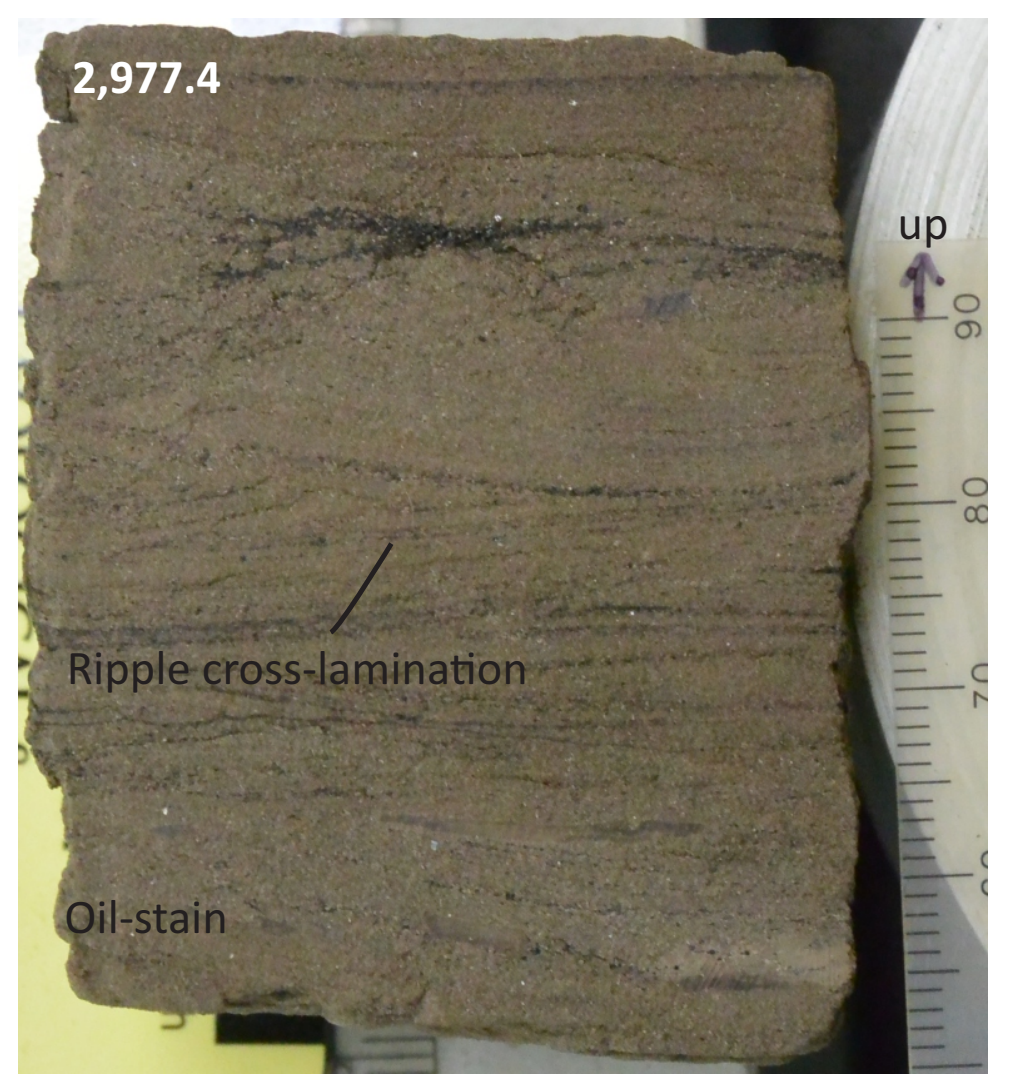



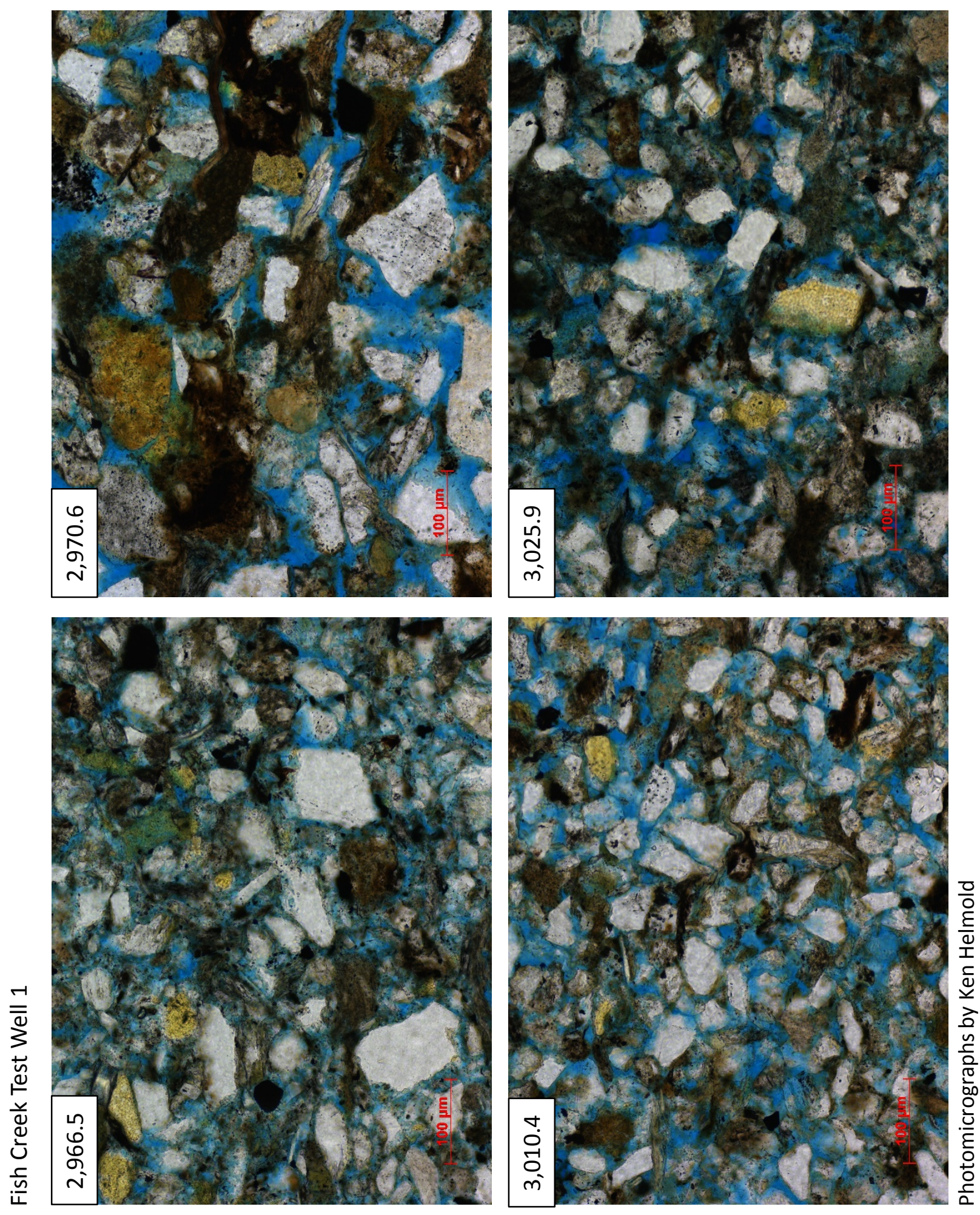


\section{QUESTIONS TO CONSIDER AND FEATURES TO LOOK FOR IN NANUSHUK CORES}

WAINWRIGHT NO. 1

Look for ripple cross-lamination in thin-bedded sandstones between 1,532-1,526 feet. Was this formed by unidirectional currents or waves?

Note possible syneresis cracks between 1,531-1,532 feet.

Note the convolute bedding in the sand body from 1,520-1,505 feet

Look for trace fossils in the sand body from 1,520-1,505 feet. How many different genera can you recognize?

Is the trace fossil assemblage diverse? Environmental significance?

Note the thick channel sand body from 1,157-1,060.5 feet. Does this represent the fill of a single channel or several stacked channels?

Note the features in the siltstone below the sand at 1,157 feet. Look for deformed bedding and thin sandstone laminae. What is the depositional environment?

Note the coaly stringers between 1,060-904 feet.

Look for rhizoliths (roots) between 991-992 feet

Note the fining-upward grain size trend in the channel sand body from $~ 666-620$ feet. What type of channel could this represent?

Note the carbonaceous-rich laminae between $654-651$ feet. What is the possible significance?

The cored succession in the Wainwright well records deposition in a delta plain setting. Where on a delta plain would you place the featured core intervals (upper or lower)?

Note the blue areas in the photomicrographs of sandstones.

\section{WOLF CREEK TEST WELL 3}

The deepest core (core 47) is most likely from the upper part of the Torok Formation $(3,746-$ 3,740 ). Look for clues that suggest depositional setting (outer shelf or slope). This core is not included in the workshop notes.

Note the sandier-upward succession from 2,195-2,113 feet. In this succession, note the planeparallel lamination in sandstones and look for subtle changes in apparent dip direction. What depositional structure could this represent?

Look for trace fossils between 2,158-2,113 feet. What does their presence/absence indicate about the depositional environment?

A flooding surface is shown on the core description in the workshop notes at about 2,035 feet. What's the evidence for a flooding surface? Do you agree with its placement? Flooding surfaces can be inferred at 2,113 feet and 1,977 feet.

How would you describe the parasequence stacking pattern between 2,195-1,886 feet? Aggradational or progradational? 
Note the muddy lithologies capping these parasequences (in cuttings and in the cores). Depending on their extent up depositional dip, these could be reservoir seals.

Note ripple cross-laminated sandstones from 1,932-1,915 feet. Look for trace fossils in this interval - possible Teichichnus, Asterosoma, Skolithos, and Palaeophycus.

Note the shallowest shorezone parasequence shown on the core description extract from 1,955$\sim 1,856$ feet. Is the contact at $\sim 1,886$ feet, between sandstone below and carbonaceous mudstone above, a flooding surface?

Note possible wave-ripple cross-lamination from 1,655- 1,646 feet. Is this sandbody bioturbated?

Do you think waves played an important role in shaping the nearshore marine setting captured in cores 26 through $12(2,190-1,895$ feet)? If these parasequences represent stacked delta front successions, how would you characterize delta style (river-dominated, wave-modified, wavedominated)?

\section{SQUARE LAKE TEST WELL 1}

Look for plane-parallel horizontal lamination and plane-parallel laminae that dip a few degrees. Can find apparent dip reversal in the latter in sand between 3,898 -3,870 feet? As in Wolf Creek Test Well 3, what structure could this represent?

Note the mudstone intervals that separate the thicker sandstone packages between 3,898-3,829 feet. How would these impact a reservoir?

The interval from 3,918-3,829 feet is characterized by a sandier upward trend. Is this the result of a single shoreline progradational cycle (single parasequence)? Is this a shoreface or a delta front succession? How do you tell the difference and does it matter?

Note the interbedded mudstone-sandstone package from 2,035-just below 1,886 feet. We interpret this as a bayfill succession. Do you agree?

Note the chert-quartz pebble lag at 1,886 feet. This is a candidate sequence boundary.

Note the flaggy parting in the sandstone from $\sim 1,883-1,843$ feet. We logged this as planeparallel, horizontal lamination. Do you agree

Look for pelecypod shell fragments (Inoceramus) between 1,853 and 1,843 feet.

Note the tightly cemented sandstone from $1,843-1,841$ feet. The cement is calcite.

Do you agree with the delta front interpretation for the sand body from $\sim 1,883-1,841$ feet. If the pebble lag is correctly associated with an unconformity, is this a lowstand shoreline?

Look for disturbed bedding in the sand at $\sim 1,767$ feet. This was likely caused by a density contrast between the sand and the underlying muddy substrate, which was probably "soupy" at the time the sand was deposited.

Note the shell fragments in the sands from $\sim 1,701-1,675$ feet.

Look for visible porosity between 1,675 and 1,665 feet. Look at the photomicrographs and note the porosity. 


\section{UMIAT 18}

Look at the gamma log and note the well-defined parasequence stacking pattern from about 1,040 to 775 feet. Lithologies in the cores are easily tied to the gamma log.

In the deepest parasequence from 1014.6 to about 970 feet, look for trace fossils. Do you see discrete traces or more a bioturbated fabric?

Look for macerated terrestrial plant material ("coffee grounds") between 1,005-1,000 feet.

Can you see possible hummocky cross-stratification between 986-979 feet.

Note the well-defined flooding surface at $\sim 970$ feet.

Look for the cluster of burrows between 948-950 feet. These look like Palaeophycus(?).

Note the possible Rosselia burrow near 940 feet.

Look for discrete event beds between 922-900 feet.

Look for more "coffee grounds" between 891-880 feet. It's obviously coming from nearby vegetated land, but what does it indicate about the depositional environment?

Look for small trace fossils in the mudstone between $872-869$ feet. These are either Phycosiphon or Heminthopsis. The former should have a bleached halo around the margins of the burrow. Is this feature present around the margins of these traces?

Look for Macaronichnus at about 833 feet. Note also the "fuzzy" appearance of the laminations in the underlying sandstone bed ( 833.5-834 feet). Is this the result of bioturbation?

It's hard to miss the coring induced fractures from about 830-815 feet. Can you see sedimentary structures in this interval despite the fractures?

Look for cross-bedding between 791-782 feet. These represent foresets to either 2D or 3D dune bedforms.

Note the well-defined flooding surface at $\sim 777$ feet.

Look for delicate, disarticulated, thin-walled pelecypod shells between $\sim 767$ and 759 feet. Is there a preferred orientation (convex up or down)?

Note the lack of bioturbation in the mudstones from about 766- 748 feet.

Look for Helminthopsis burrows between 746-737 feet.

This core clearly emits a strong hydrocarbon odor, which is consistent with the resistivity log. Linc perforated the interval from 775-835 feet, but was unable to produce fluid.

\section{FISH CREEK TEST WELL 1}

Note the bioturbated fabric around 3,384 feet.

Note the thinly interbedded mudstone and coarse siltstone between 3,376-3,356 feet. Look for sedimentary structures - can you find any?

Look for horizontal, plane-parallel lamination between 3,181-3,171 feet. Note the bioturbated fabric in this interval.

Look for the first appearance of oil staining between 3,041-3,043 feet. 
Note the abundance of oil-stained sandstones from $~ 3,037-2,067$ feet.

Is oil-staining limited to sandstone? Look between 2,958-2,953 feet.

In general, note the common presence of small coalified plant fragments throughout.

We interpret the depositional setting as distal shelf. Do you agree? 